\title{
Pirin metamorphic and igneous evolution revisited in a geochronological frame based on $\mathrm{U}-\mathrm{Pb}$ zircon studies
}

\author{
Ivan Zagorchev ${ }^{l}$, Constantin Balica ${ }^{2}$, Evgeniya Kozhoukharoval, \\ Ioan Coriolan Balintoni ${ }^{2}$ \\ ${ }^{1}$ Geological Institute, Bulgarian Academy of Sciences, 1113 Sofia, Bulgaria; e-mail: i_zagorchev@geology.bas.bg \\ 2 Babeş-Bolyai University, RO-400084, Cluj-Napoca, Romania; e-mail: constantin.balica@ubbcluj.ro \\ (Accepted in revised form: July 2017)
}

To the memory of Prof. Stephen Erwin Moorbath, F.R.S.

\begin{abstract}
New isotopic data obtained from zircons by the U-Pb method during the last decade show the necessity of a revision of the tectonometamorphic and igneous evolution of the Pirin-Pangaion Unit of the Alpine Morava-Rhodope tectonic zone. The northern (Pirin) subunit of this unit consists of four areas built up of metamorphic rocks (amphibolite facies) of the Rhodopian supercomplex. These areas are separated by Late Alpine granite plutons of batholithic dimensions. The northernmost (Krupnik) area is built up of rocks of the Rupchos Group (complex) of varied composition and intense multiphase deformation and metamorphism. The oldest metamorphic phase is dated as Cadomian (528-517 Ma), and its products also suffered Hercynian superimposed amphibolite-facies metamorphism and anatexis. A septum of granitised metamorphics preserved between the Krupnik granite pluton (Triassic, ca $240 \mathrm{Ma}$ ) and the early Oligocene North Pirin (Kresna) pluton is characterised by Hercynian (330-300 Ma) anatexis. The principal metamorphism within the southern area around the early Oligocene South Pirin (Teshovo) granite pluton is dated both in the Bachkovo quartzo-feldspathic gneisses (named also Kriva-reka metagranites or orthogneisses) and in the Lukovitsa schists and paragneisses as Hercynian (ca 300-290 Ma). Therefore, the polymetamorphic evolution of the Pirin Subunit consists of a Cadomian phase and a strong Hercynian overprint followed by Triassic granitoids. We confirm the Thanetian-early Eocene age (58-55 Ma) of the Spanchevo granite, partially formed by in situ anatexis. Its intrusion was followed by a compression phase during the mid-Eocene thrusting of the Ograzhden Unit over the Pirin-Pangaion Unit, along the Strimon Thrust. The last magmatic phase (ca 34-31 Ma) was represented by a granitoid association formed during the latest Eocene-early Oligocene in extensional conditions and as a result of mixing of anatectic crust-derived magma with magma of mantle origin. It was part of a volcano-plutonic association related to the Macedonian-Rhodope magmatotectonic province. A high-temperature metamorphic overprint of the same age is recorded in the metamorphics as formation of andalusite in the metapelites, and skarns at the contacts of some of the granitoid bodies.
\end{abstract}

\begin{abstract}
Zagorchev, I., Balica, C., Kozhoukharova, E., Coriolan Balintoni, I. 2017. Pirin metamorphic and igneous evolution revisited in a geochronological frame based on U-Pb zircon studies. Geologica Balcanica 46 (1), 27-63.
\end{abstract}

Keywords: U-Pb geochronology, tectonometamorphic and igneous evolution, Pirin-Pangaion Unit.

\section{INTRODUCTION}

The Pirin-Pangaion Unit (Zagorčev, 1989, 1994) has an important position in the Rhodope tectonometamorphic edifice (Fig. 1). Geological mapping in scales 1:100 000 and 1:25 000 has revealed an intricate structure, and thorough studies in Bulgaria and Greece have demonstrated that the unit is located in lowermost position in the suggested nappe pile of the Rhodopes (Zagorčev, 1994; Burg et al. 1996; Burg, 2011). Extensive structural, petrological, and geochemical studies in Bulgaria and Greece during the last 20 years have brought important new evidence and new (and sometimes, surprising) dating of the metamorphic and 


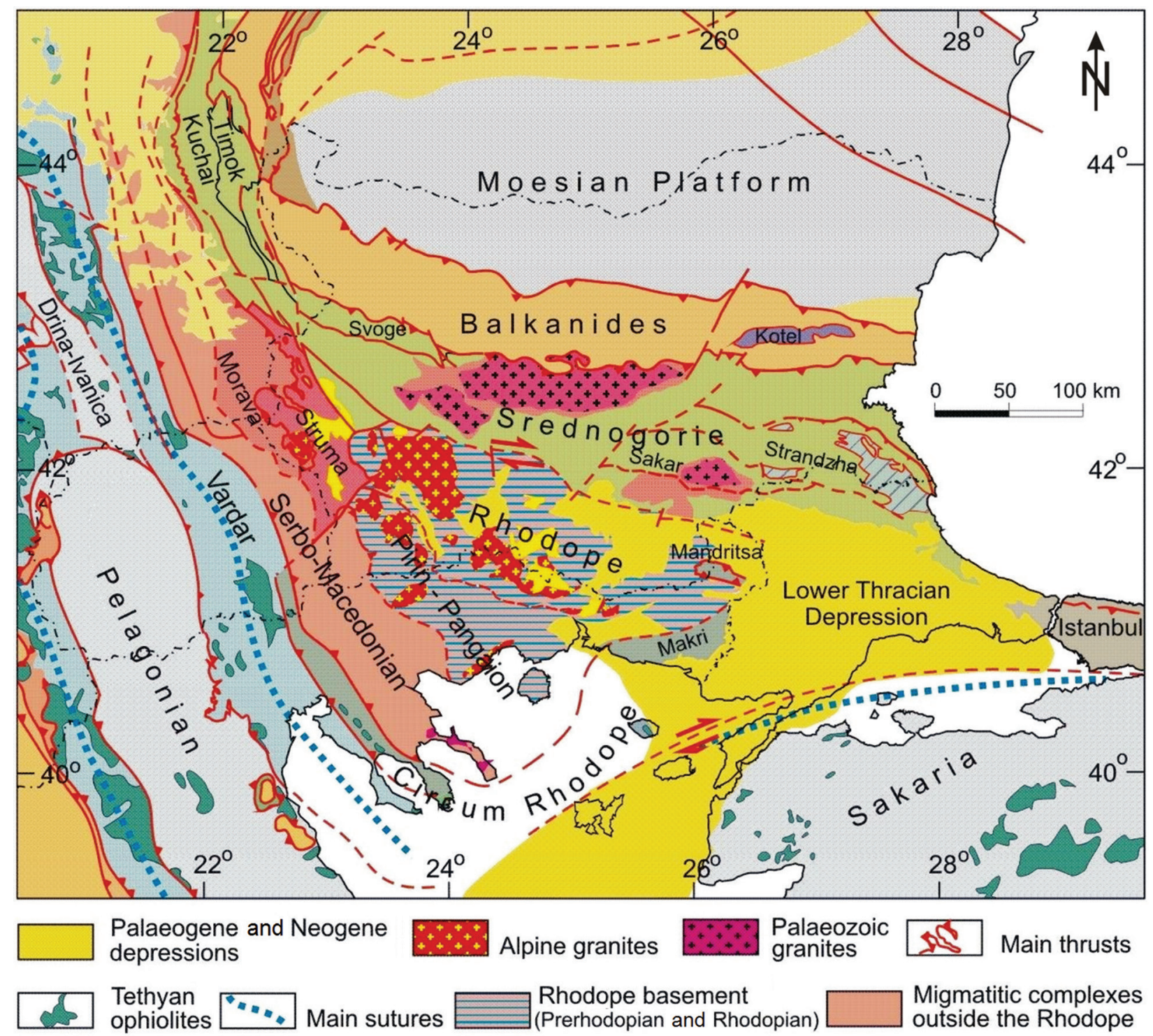

Fig. 1. Position of the Pirin-Pangaion Unit in the geological structure of the Rhodopes and the eastern parts of the Balkan Peninsula (after Zagorchev, 2014, with revisions).

igneous events. A revision of older data and new interpretation of both the revisited old and newly obtained evidence is of obvious necessity.

The modern geological studies of the Pirin Mountain on Bulgarian territory began with the geological mapping in the scale 1:100 000 under the leadership of S. Boyadjiev (Boyadjiev, 1959) and the 1:25000 mapping in Southern Pirin and Slavyanka headed by D. Kozhoukharov. The next stage coincided with the mapping of the whole mountain in scale 1:25 000 during 1966-1969 and the publication of three review papers based upon these studies (Zagorčev et al., 1974; Zidarov et al., 1974; Slavov et al., 1976). The state geological map in scale 1:100 000 (Kozhoukharov and
Marinova, 1991a, b; Zagorčev and Dinkova, 1989, 1991; Zagorčev and Marinova, 1991, 1993; Marinova and Katzkov, 1990) was also based on these studies and on extensive revisions, the existing information having been summarised by Zagorchev (1994a; 1995, 2001). Since that time, revisions of the geological maps and their printing in scale 1:50 000 and some $\mathrm{U}-\mathrm{Pb}$ datings on zircons, mostly from the igneous rocks, have changed considerably the time frame of the major igneous events. Hypotheses have been emitted in respect to the timing of metamorphism and the time of exhumation of the metamorphic complexes. Major controversies exist not only in respect to the tectonometamorphic development (see Zagorchev, 
1998), but also about the Cenozoic tectonics and neotectonics (see Zagorčev, 1992; Dinter and Royden, 1993; Sokoutis et al., 1993; Burchfiel et al., 2000).

In view of the new isotopic evidence obtained throughout the Rhodopes, and the lack of modern studies within the Pirin Subunit, the present authors undertook new field and laboratory studies. The results have been partially published in several preliminary publications and conference abstracts (Zagorchev et al., 2012, 2015, 2016). The full account of the new and of the older published data and an attempt for reappraisal of the geologic evolution of the subunit in the light of the existing evidence are made with the present paper. We first make a review of the geological data about the metamorphic and igneous rocks of the subunit. Then, we report the results from our isotopic studies, followed by brief discussions and conclusions.

The problems of the Neogene exhumation phase(s) are not discussed in the present paper. They are only slightly concerned with the herein-reported U-Pb isotopic data on zircons. The numerous publications on the Rhodopes exhumation have been recently supported by detailed parallel isotopic, thermochronological, sedimentological, structural (Stübner et al., 2015), and magnetic (Van Hinsbergen et al., 2008) studies and require special attention.

\section{METHODS AND PROCEDURES}

The first isotopic geochronological studies were made on the granitoid rocks of the Teshovo (South Pirin) pluton as early as in 1956 by N. Yordanov (U-Pb studies on allanite; see Slavov et al., 1976); they are now only of historical interest. The first important results by the $\mathrm{Pb}-\mathrm{Pb}$ studies performed by $\mathrm{B}$. Amov (Amov et al., 1982; Arnaudov and Arnaudova, 1982) confirmed previous K-Ar results (Boyadjiev and Lilov, 1976) about the Alpine age of the Pirin-type granites, and the final confirmation came from the Rb-Sr studies (Zagorčev and Moorbath, 1983; Zagorčev et al., 1987, 1989). Considerable progress of the U-Pb zircon geochronology achieved during the last two decades enabled a more precise dating and led to corrections of some of the results previously obtained by other methods. In the present paper, we concentrate on results obtained during the last ten years by the U-Pb method on zircons (for the metamorphics - Machev and Ovcharova, 2008; Zagorchev et al., 2012), and report in details data previously unpublished and/or mentioned in preliminary publications. The isotopic geochronological evidence is commented and explained at the background of older and new field observations.

Sampling was made with emphasis on areas that lack previous datings and exhibit clear field relations between already known rock bodies. We concentrated on two areas of complex structure and several generations of granitoids (granitoid neosome in migmatites; diatectites; foliation-parallel and cross-cutting granite bodies and dykes) described herein as area 1 (Krupnik) and area 3 (Southern Pirin). Fresh rock samples weighing between $5 \mathrm{~kg}$ and $10 \mathrm{~kg}$ were sampled from each outcrop, and their processing followed the procedure already published by Zagorchev et al. (2012). The brief description is almost entirely repeated herein. Each sample was subjected to the classical techniques of crushing, milling, gravitational separation, and heavy liquid treatment at the facilities of BabeşBolyai University. At least 100 zircon grains were randomly selected from each sample, using a stereomicroscope, and then mounted in $25 \mathrm{~mm}$ epoxy and polished. For igneous samples, a minimum of 25 zircon grains free of inclusions or cracks were selected, mounted, and polished.

The LA-ICP-MS measurements were performed at the LaserChron facility, Department of Geosciences, University of Arizona, using an ISOPROBE MCICPMS equipped with a New Wave DUV193 nm Excimer. A laser spot diameter of $35 \mu \mathrm{m}$ was used for all analyses.

Prior to analysis, each zircon was subjected to cathodoluminescent (CL) imaging. CL maps of all sampled zircons were used for screening and orientation purposes for choosing the ablation points. The latter are concentrated mostly on presumable magmatic domains (inherited cores or magmatic? overgrowths) of zircon, the outer metamorphic rims being very narrow to be safely ablated as to avoid mixing.

Each grain analysis consisted of single 20 -second integration without laser firing to obtain on-peak background levels, 20 one-second integrations with the laser firing, followed finally by a 30 -second purge with no laser firing in order to deliver out the remaining sample. Mercury contributions to ${ }^{204} \mathrm{~Pb}$ were removed by taking on-peak backgrounds. The ablated material was carried via argon gas into the IsoProbe, which is equipped with a sufficiently wide flight tube to allow $\mathrm{U}$ and $\mathrm{Pb}$ isotopes to be measured simultaneously. Measurements were made in static mode, using Faraday detectors for ${ }^{238} \mathrm{U},{ }^{232} \mathrm{Th},{ }^{208} \mathrm{~Pb},{ }^{207} \mathrm{~Pb},{ }^{206} \mathrm{~Pb}$, and an ion-counting channel for ${ }^{204} \mathrm{~Pb}$. Common $\mathrm{Pb}$ corrections were made, using the measured ${ }^{204} \mathrm{~Pb}$ and assuming initial $\mathrm{Pb}$ compositions from Stacey and Kramers (1976). Analyses of zircon standards of known isotopic and $\mathrm{U}-\mathrm{Pb}$ composition were conducted in most cases after each set of five unknown measurements to correct for elemental isotopic fractionation.

The samples were analysed in hard extraction mode. The ${ }^{206} \mathrm{~Pb}^{* / 238} \mathrm{U}$ values for the standards were corrected for an average of $15.3 \%( \pm 2.6 \%)$ and $27.2 \%$ $( \pm 3.0 \%)$ fractionation (uncertainties at $2 \sigma$ standard deviation of $\sim 20$ analyses), respectively. Concordia diagrams were plotted for each sample by the ISOPLOT program (Ludwig, 2001). The U/Pb measurements, ratios, ages, and errors are are reported as supplementary data (see APPENDIX, Tables A1-A10). Uncertainties shown in these tables are at the $1-\sigma$ level and include only measurement errors. Analyses that are $>20 \%$ dis- 
cordant (by comparison of ${ }^{206} \mathrm{~Pb} /{ }^{238} \mathrm{U}$ and ${ }^{206} \mathrm{~Pb} /{ }^{207} \mathrm{~Pb}$ ages) or $>5 \%$ reverse discordant are not considered further. The 'best age' refers to ${ }^{206} \mathrm{~Pb} /{ }^{238} \mathrm{U}$, all ages recorded being less than $1 \mathrm{Ga}$. Asterisks indicate the radiogenic isotopes.

\section{REGIONAL AND STRUCTURAL-GEOLOGICAL OVERVIEW}

The Pirin-Pangaion Unit (Zagorčev, 1994a) is situated (Figs 1,2) within the territories of Bulgaria and Greece, and geographically embraces the mountains Pirin (in the north, the Krupnik Mountain inclusive), Stargach, Slavyanka (at the Bulgarian-Greek border, also called Orvilos, Alibotush), Vrondou, Falakro, Menikion, Pangaion, Symvolon, and Lekanis situated between the rivers Struma (Strymonas) and Mesta (Nestos), as well as the island of Thassos.

The unit is covered at NE and E by the WestRhodope Unit sensu Zagorčev (1995) (equivalent to the middle Rhodope nappes sensu Burg, 2011), and from the SW by the Ograzhden Unit along the Strimon Thrust ("Strimon Überschiebung", "Strimon Linie" sensu Kockel and Walther, 1965). The latter has been partially transformed into several low-angle normal faults (see Zagorčev, 1992, and references therein) of the West-Pirin fault zone (interpreted by Dinter and Royden, 1993, and by Sokoutis et al., 1993, as a Strymon Detachment, and discarded as such by Zagorčev, 1994b, c, and Brun and Sokoutis, 2007).

The boundary between the Pirin Subunit (almost entirely on the territory of Bulgaria) and the Pangaion Subunit (in Northern Greece) is traced along the Middle Mesta fault zone (Zagorčev, 1992). The basic differences between the two subunits are controlled by the late Cenozoic extension and uplift. Another important difference is the lack of rocks equivalent of the Rupchos Group within the Pangaion Subunit.

The Cenozoic tectonics of Pirin is controlled by the wide presence of Alpine granitoids. The original concepts (Dimitrov, 1959; Boyadjiev, 1959) considered the Pirin structural pattern as consisting of three large anticlines cored by the three largest plutons: Northern Pirin (Dautov, Kresna), Central Pirin, and Southern Pirin (Teshovo). Zagorčev et al. (1974) and Zagorčev (1994a) proved that the metamorphic complex of Pirin possessed a complex pre-granitic structure (then believed to be of Precambrian or Palaeozoic age) and that the three major plutons were superimposed discordantly over this older structural pattern. The older pre-granitic metamorphic rocks of the Rhodopian supercomplex are preserved at the peripheries and in between the plutons, and each of the major exposures (called herein areas) is characterised by a specific structural pattern (Fig. 2). This conclusion has been confirmed by all consecutive mapping campaigns in Pirin. Another important feature is the multiphase character of the granitoid activity (Boyadjiev,
1959, 1989; Georgiev, 1973; Zagorčev et al., 1974; Slavov et al., 1976; Zagorčev, 1994a). The similarities in composition and age between the youngest Palaeogene granitoids of Pirin and the Mesta and Padesh volcanics gave grounds to suggest that they belong to a common volcano-plutonic association (Slavov et al., 1976).

The four metamorphic areas of the Pirin Subunit may be outlined as follows (Fig. 2):

(1) NW (Krupnik) area - to the NW of the North Pirin pluton;

(2) Sinanitsa area - between the North Pirin and the Central Pirin pluton;

(3) Western Pirin (Lilyanovo) area;

(4) Southern Pirin area - around the Southern Pirin (Teshovo) pluton.

Another area (Obidim area) crops out as a discontinuous strip along the Mesta River Valley between Bansko and Obidim, does not belong to the Pirin subunit s.str., and is briefly discussed here for comparison purposes.

Each of these areas has specific structural features (Zagorčev et al., 1974; Zagorčev, 1994a).

The Krupnik area is disrupted by tectonic and intrusive structures, and the metamorphic rocks have a limited occurrence. From the southwest, they are overthrust by the Ograzhdenian supercomplex of the Ograzhden Unit along the Alikochov thrust regarded as a part of the Strimon Thrust. The low-angle thrust faults have been partially transformed into low-angle normal faults, as suggested by Milovanov et al. (2009). The age of this thrusting postdated the intrusion of the Krupnik pluton and predated the early Oligocene Northern Pirin pluton. The whole section of the metamorphic rocks is in overturned position and is strongly folded in recumbent isoclinal folds. They have been refolded in an intricate manner during still undated fold phase with abundant syntectonic migmatisation. The Krupnik pluton is post-tectonic in respect to this phase. Its host rocks at the eastern contact have been reduced to a thin septum of metamorphics that separate the pluton from the much younger Northern Pirin (Dautov, Kresna) pluton.

The metamorphic rocks of the Sinanitsa area (area 2) are preserved between the two biggest Oligocene plutons, the Northern Pirin and the Central Pirin pluton (Fig. 2). The metamorphics outline the huge Sinanitsa anticline, the strongly reduced Kurtovo anticline, and the Razkola and Sharaliya synclines situated between them. The structures trend NNE-SSW and have been refolded at the north-northeastern and south-southwestern peripheries (periclinal parts of the Sinanitsa anticline) by cross structures. At the northnortheastern periphery, the Yavorov anticline and a parallel syncline are southwest-verging tight to isoclinal structures. They were possibly controlled by the southwest-vergent thrusting of the West-Rhodope Unit over the Pirin-Pangaion Unit (Zagorčev, 1994a). At the south-southwestern periphery, a complex inter- 

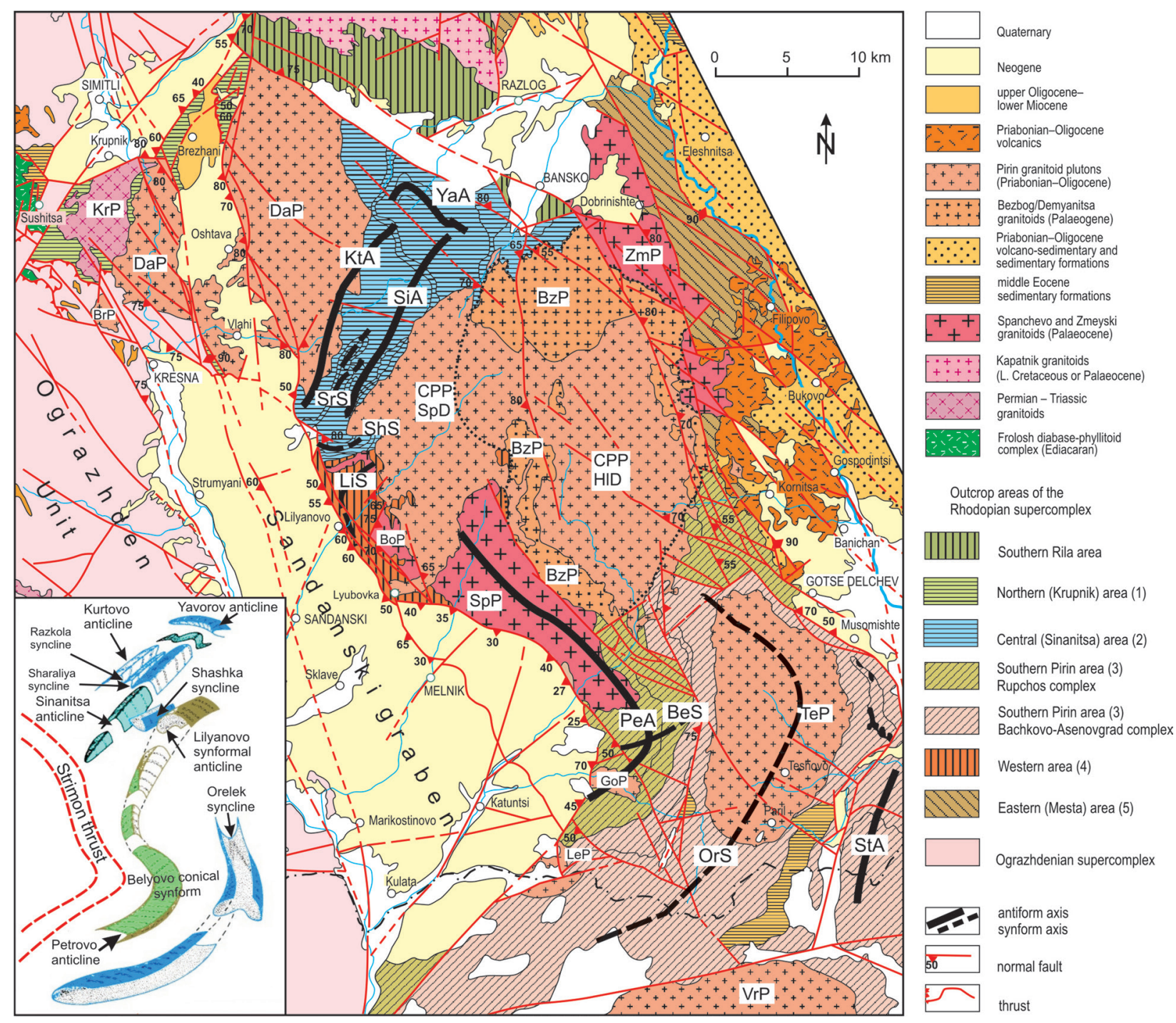

Fig. 2. Map of the Pirin Subunit with schematic representation of the metamorphic areas, the fold axes, and the names of the granitoid plutons. The suggested pre-Palaeogene fold structure is shown in the inset as block-diagram (after Zagorčev, 1994). Main fold structures: BeS - Belyovo conical syncline; KtA - Kurtovo anticline; LiS - Lilyanovo synformal anticline; OrS - Orelek syncline; PeA - Petrovo anticline; ShS - Shashka recumbent syncline; SiA- Sinanitsa anticline; SrS - Sharaliya syncline; StA - Stargach anticline; YaA - Yavorov anticline. Granitoid plutons: BoP - Bozhdovo pluton; BzP - Bezbog pluton (supposed initial outline marked with dotted line); CPP - Central Pirin pluton (HID - Hleven dome, SpD - Spano pole dome); DaP - Dautov pluton; GoP Goleshevo pluton; KrP - Krupnik pluton; LeP - Lehovo pluton; SpP - Spanchevo pluton; TeP - Teshovo pluton; VrP - Vrondou pluton; ZmP - Zmeyski pluton.

ference pattern is marked by the north-northwestward overturning, with possible thrusting of the northern parts of the sigmoidal Petrovo anticline from the Lilyanovo area over the recumbent Shashka syncline (Fig. 2) exposed within the Dobrostan Marble Formation (Zagorčev et al., 1974; Zagorčev, 1994a).

The metamorphic rocks of the Lilyanovo area (area 3) crop out between the West Pirin fault zone, the Spano Pole dome of the Central Pirin pluton, and (to the north) the strongly squeezed southern limb of the recumbent Shashka syncline. The northernmost parts of the Spanchevo pluton have been intruded into these rocks, and the outcrops of the Bozhdovo "pluton" (most probably, a part of the Spanchevo pluton itself, later displaced by the intrusion of the Central Pirin pluton) and of a smaller foliation-parallel body north of Lilyanovo are entirely intruded into these metamorphics. Two xenoliths built up of similar rocks are situated at the western border of the Bezbog pluton (Fig. 2). The metamorphic rocks within the Lilyanovo area build a synformal structure thrust over the Shashka syncline. This structure was first described 
(Zagorčev et al., 1974; Zagorčev, 1994a) as the Lilyanovo synformal anticline (synclinaloid) comprising rocks of the Rupchos Group (similar to these in the core of the Petrovo anticline, area 4) overturned over the Shashka recumbent syncline. Machev and Veit (2001), Machev et al. (2005), and Klimov et al. (2009) referred without serious argumentation these rocks to the Ograzhdenian supercomplex, allegedly thrust over the Sinanitsa complex along the Lilyanovo shear zone.

The Southern Pirin area (area 4) is the biggest area of metamorphic exposures in Pirin. Three parts may be distinguished. In the western part, the tight eastvergent Petrovo anticline (unpublished map and report of D. Kozhoukharov et al., 1958) is built up of rocks of the Rupchos Group. The same rocks build up the northeastern parts of the area, and they are characterised by a western vergence. The central part is built up of the Sitovo and Asenovgrad groups, with dominant exposure of the Dobrostan Marble Formation. Further east within the Stargach Mountain, the normal Stargach anticline trends nearly north, with a north-plunging axis. A synclinal isoclinal fold (Lyalevo syncline) is detected at the abandoned village of this name. The structure of the area is characterised by several typical features. Thus, the Petrovo anticline has a sigmoidal shape, with northwestern vergence of the northern part, and eastern and southeastern vergence of the southern part. The southern part was deformed by a late synformal structure of conical geometry (Belyovo conical synform), which post-dated the intrusion of the Spanchevo pluton but predated the Southern Pirin (Teshovo) pluton. On the other hand, the primary structure of the southern Pirin area may be considered as centred by the primary Orelek syncline, which has been antivergently overthrust by the Petrovo anticline from the west, and the strongly deformed and disrupted eastern flank (NNE of Popovi livadi), which has a western vergence. The Teshovo pluton has a well-visible domal structure that has been superimposed over the older synclinal structure (Orelek syncline) of the Dobrostan Marble Formation.

The Obidim area (area 5) does not belong to the Pirin structure s.str. and is partially discussed here for comparisons. It is situated to the northeast of the old Mesta (Nestos) shear zone and has probably been imbricated together with parts of the West Rila and West Rhodope structural subunits (Zagorchev, 1995) over the Pirin-Pangaion Unit.

\section{Metamorphic complexes}

The nomenclature of the metamorphic complexes of Pirin has been subject of different interpretations, issued from the geological mapping and from the dominant approaches, hypotheses, and paradigms.

The first detailed subdivisions of Pirin lithostratigraphic units were made by Boyadjiev (1959) and D. Kozhoukharov et al. (unpublished map and explanatory note, 1958). The geological mapping in scale 1:25 000 (1966-1969) resulted in an informal lithostratigraphic scheme (Zidarov et al., 1974), further correlated (Kozhoukharov and Marinova, 1991; Zagorčev and Dinkova, 1989, 1991; Marinova and Zagorčev, 1990, 1993) with the formal scheme of Kozhoukharov (1984) for the Central Rhodopes. The same scheme has been accepted in a number of publications. It is based upon the observed similar superpositions of metamorphic lithostratigraphic units correlated throughout the territory of the Rhodope Mountains that can be related to primary superpositions of

Table 1

Comparison of the lithostratigraphic schemes of Pirin

\begin{tabular}{|c|c|c|c|c|c|}
\hline $\begin{array}{l}\text { Zidarov et al. (1974); } \\
\text { maps 1:100 } 000\end{array}$ & & $\begin{array}{l}\text { Northern and Central Pirin: } \\
\text { Milovanov et al. (2009) }\end{array}$ & $\begin{array}{l}\text { Southern Pirin: } \\
\text { Klimov et al. (2009) }\end{array}$ & \multicolumn{2}{|c|}{ Zagorchev (2008) } \\
\hline $\begin{array}{l}\text { Asenovgrad Group, } \\
\text { Dobrostan Marble Formation }\end{array}$ & \multirow{6}{*}{ 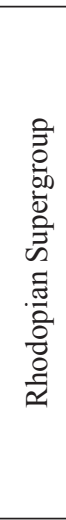 } & $\begin{array}{l}\text { Sinanitsa metamorphic } \\
\text { complex, marble formation }\end{array}$ & $\begin{array}{l}\text { Orelek metamorphic complex, } \\
\text { massive marbles }\end{array}$ & \multirow{2}{*}{$\begin{array}{l}\text { Asenovgrad } \\
\text { complex }\end{array}$} & \multirow{6}{*}{$\begin{array}{l}0 \\
\\
0 \\
0 \\
0 \\
0\end{array}$} \\
\hline $\begin{array}{l}\text { Sitovo Group, Lukovitsa } \\
\text { Varied Formation }\end{array}$ & & $\begin{array}{l}\text { Sinanitsa complex, } \\
\text { Banderitsa metamorphics }\end{array}$ & $\begin{array}{l}\text { Orelek metamorphic complex, } \\
\text { two-mica- and biotite-gneiss, } \\
\text { amphibolite }\end{array}$ & & \\
\hline $\begin{array}{l}\text { Sitovo Group, Boykovo and } \\
\text { Bachkovo formations }\end{array}$ & & $\begin{array}{l}\text { Sinanitsa complex, } \\
\text { Vihren gneisses }\end{array}$ & $\begin{array}{l}\text { Orelek met. complex, } \\
\text { Kriva-reka orthogneisses }\end{array}$ & $\begin{array}{l}\text { Bachkovo } \\
\text { complex }\end{array}$ & \\
\hline $\begin{array}{l}\text { Rupchos Group, Vacha } \\
\text { Varied Formation }\end{array}$ & & \multirow{3}{*}{$\begin{array}{l}\text { Predela metamorphic } \\
\text { complex }\end{array}$} & Belyovo metamorphic & \multirow{3}{*}{$\begin{array}{l}\text { Rupchos } \\
\text { complex }\end{array}$} & \\
\hline $\begin{array}{l}\text { Rupchos Group, Bogutevo } \\
\text { Formation }\end{array}$ & & & complex & & \\
\hline $\begin{array}{l}\text { Rupchos Group, Chepelare } \\
\text { Varied Formation }\end{array}$ & & & \multirow{3}{*}{ Ograzhden complex } & & \\
\hline Maleshevska Group & \multirow{2}{*}{$\begin{array}{l}\text { Ogr } \\
\text { SG }\end{array}$} & \multirow{2}{*}{ Ograzhden complex } & & \multirow{2}{*}{\multicolumn{2}{|c|}{$\begin{array}{l}\text { Ograzhdenian } \\
\text { supercomplex }\end{array}$}} \\
\hline Troskovo Group & & & & & \\
\hline
\end{tabular}


the protoliths. Based on the composition of the protoliths and on the local and regional structures, several attempts for different reconstructions of the protolithic sections have been published (see Kozhoukharova, 2008; Zagorchev, 2008).

Another approach was applied during the geological mapping in scale 1:50 000 (Klimov et al., 2009; Milovanov et al., 2009; Sarov et al., 2008, 2010). It is based upon the distinction of numerous lithotectonic units, each one with tectonic synmetamorphic contacts with the adjacent units and consisting of layered or/and non-layered bodies of metamorphic rocks. $\mathrm{U}-\mathrm{Pb}$ ages on zircons obtained from these rock units are considered usually as protolith ages, and several attempts for correlation based on these dates (Burg, 2011; Sarov, 2012) have been made on the regional scale for the whole territory of the Rhodope Massif or its Bulgarian part.

A comparative presentation of the nomenclature of the lithostratigraphic and lithotectonic subdivisions is presented in Table 1.

Whereas the ages of the granitoid bodies are relatively well constrained, the isotopic studies within the areas of metamorphic outcrops are restricted mostly to area (1), with a few determinations from areas (4) and (5).

\section{Metamorphic rocks of the northern (Krupnik) area (1)}

The section (Figs 3,4) has been extensively studied (Zagorčev et al., 1971; Zagorchev, 1995; Milovanov
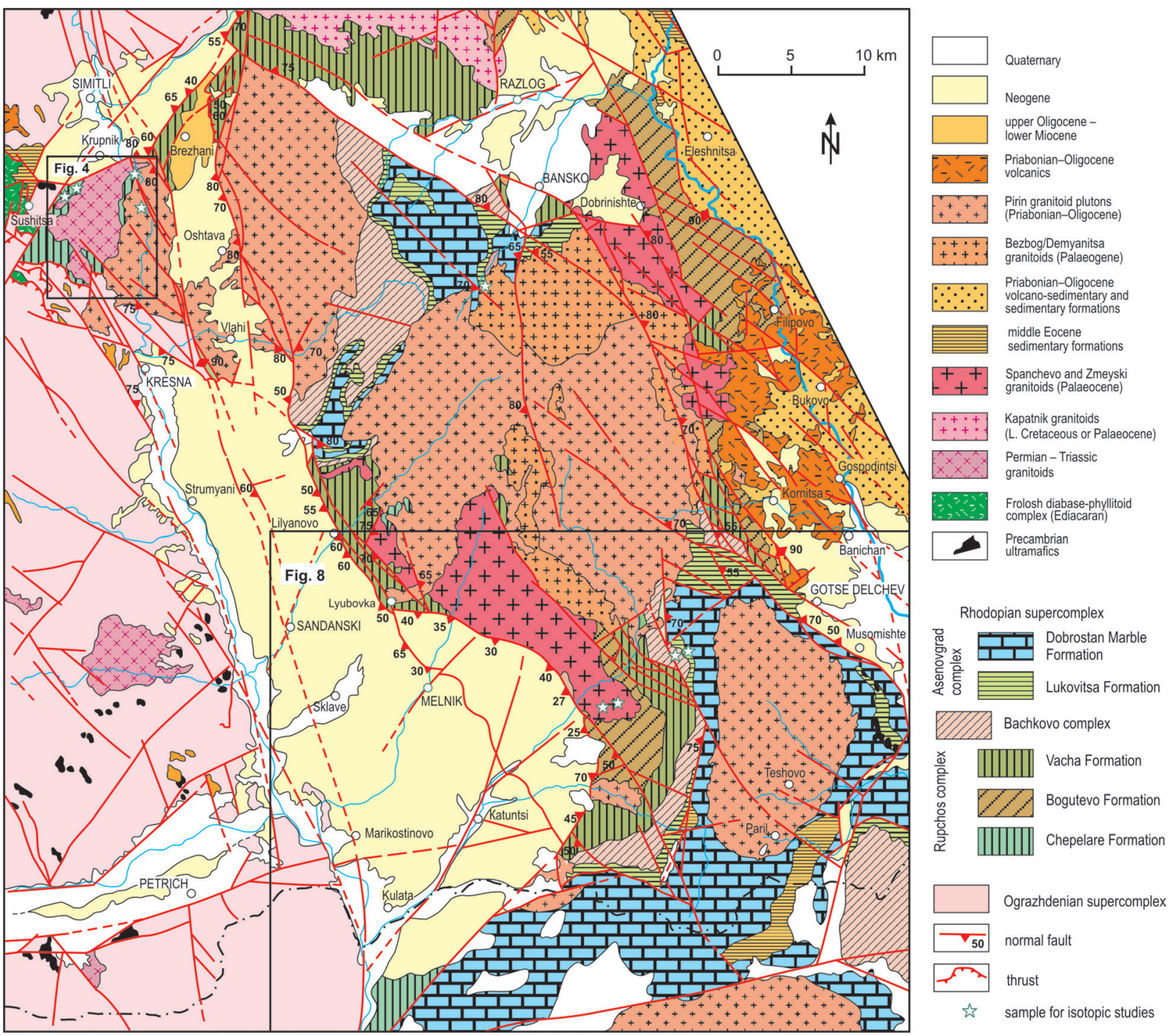

Fig. 3. Geological map of the Pirin Subunit of the Pirin-Pangaion Unit (after Zidarov et al., 1974, and Zagorchev, 1995, with revisions). The areas of Figs 4 and 8 are shown with quadrangles. 

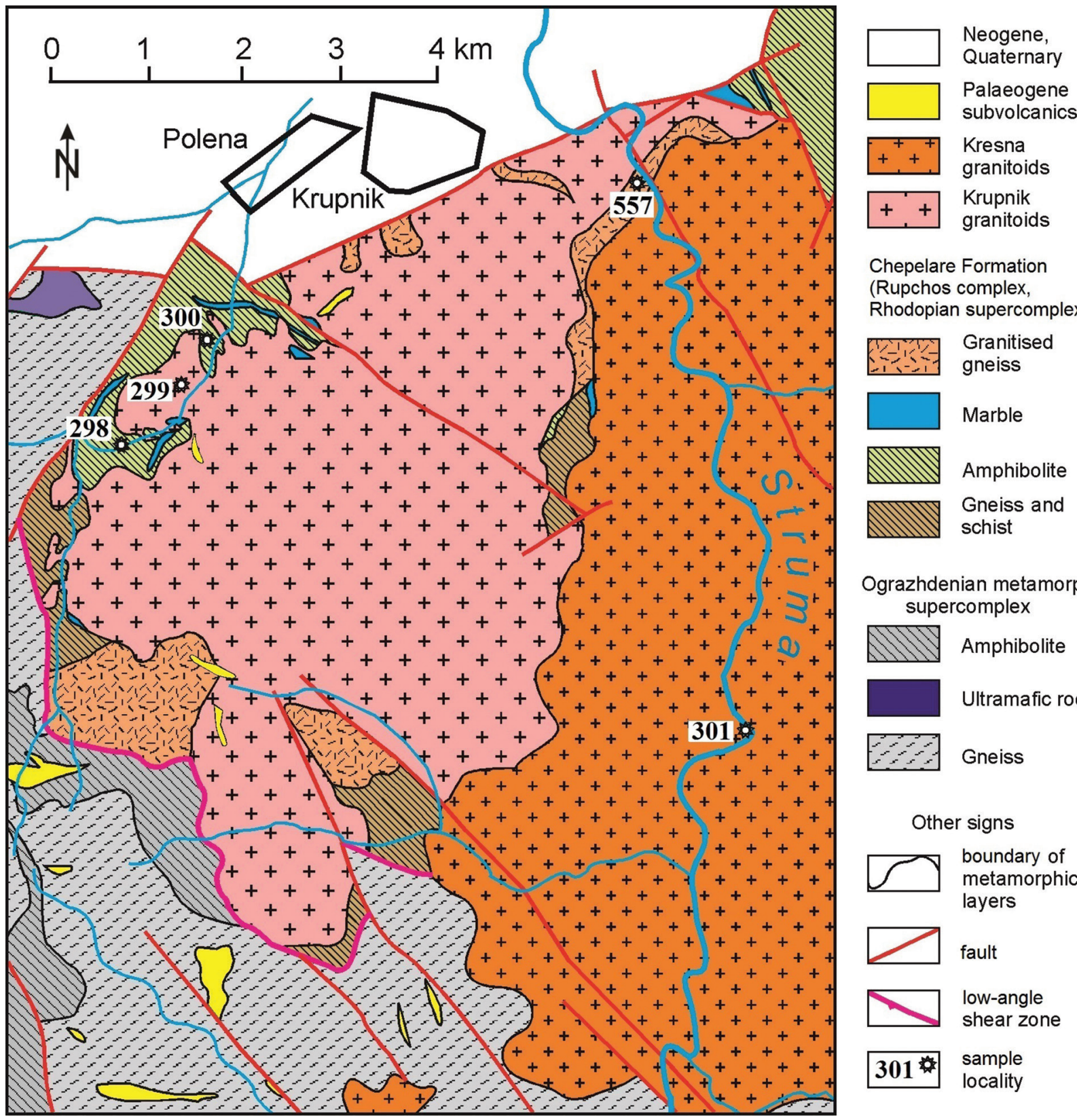

Chepelare Formation

(Rupchos complex,

Rhodopian supercomplex

Granitised
gneiss

$\square$ Marble

M.U. Amphibolite

IIIV Gneiss and schist

Ograzhdenian metamorphic supercomplex

\section{mily Amphibolite \\ Ultramafic rock \\ Gneiss}

\section{Other signs}

$\checkmark \begin{aligned} & \text { boundary of } \\ & \text { metamorphic }\end{aligned}$ layers

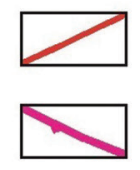

fault

low-angle shear zone

301 sample

Fig. 4. Geological map of the northernmost (Krupnik) area of the Pirin Subunit (after Zidarov et al., 1974, Milovanov et al., 2009, and Zagorchev et al., 2012).

et al., 2009; Zagorchev et al., 2012) along the road between the villages of Polena and Sushitsa. Herein, a band of metamorphic rocks is exposed between the Polena fault at NW and the granitoids of the Krupnik pluton to the SE. The rock superposition was described (Zagorchev et al., 2012) from top to bottom (from the places above Polena towards Sushitsa, i.e., from NE to SW) as follows:

(1) alternation of biotite schists and gneisses, often garnet-bearing, with amphibolites, quartzo-feldspathic gneisses, calcareous schists, marbles, and boudinaged diopside-bearing quartzose marbles; the uppermost parts of the section to the north of the road contain lenticular rootless bodies of tremolite- and talc-bearing ultramafic rocks, apoharzburgitic serpentinites, and amphibolitised pyroxenites;

(2) interlayering of biotite schists, gneisses, and migmatites with amphibolites and quartzo-feldspathic gneisses;

(3) quartzo-feldspathic gneisses interlayered with amphibolites and two-mica gneisses and schists;

(4) amphibolites and garnet amphibolites interlayered with biotite gneisses and quartzo-feldspathic gneisses (Fig. 5a-c); 

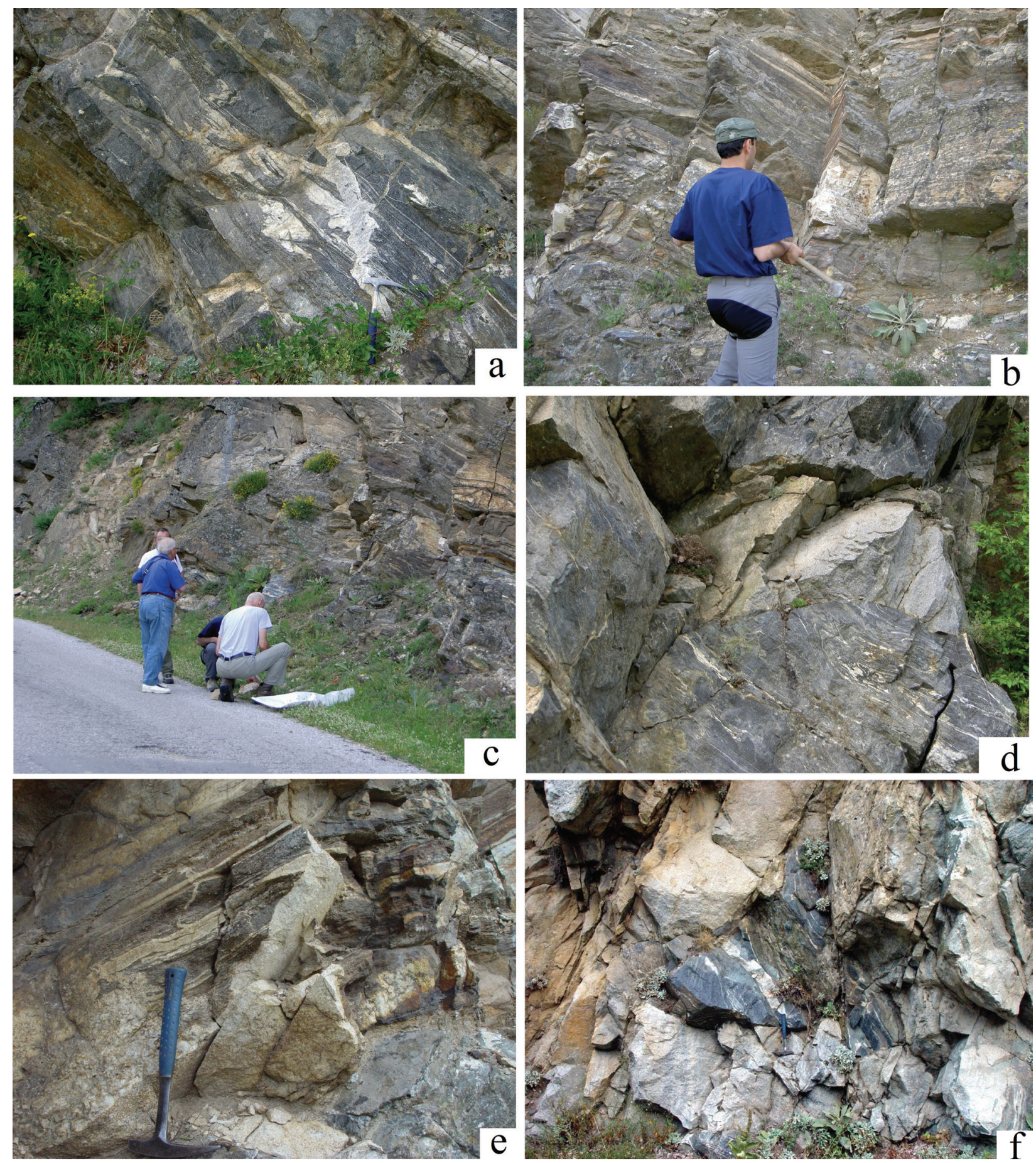

Fig. 5. Amphibolites (Chepelarska Fm.?, Rupchos Group) and Krupnik granites. Northernmost (Krupnik) area of the Pirin Subunit, road between the villages Sushitsa and Polena. $a-c)$ amphibolites with different stages of migmatization near $(a)$ and at the sampling site (sample 298); $d, e$ ) amphibolites $(d)$ and gneisses $(e)$ with dykes of Krupnik granite; $f$ ) xenolith of amphibolite with quartzo-feldspathic layer-parallel veins within the Krupnik granite site of sample 299.

(5) amphibolites, biotite gneisses, and schists with garnet, kyanite, and staurolite (exposures south of the road, continuing south to the Alikochov thrust that separates them from the migmatites of the Ograzhdenian supercomplex).
The whole section described has been subject of multiple, but irregular, anatexis and flow. Different degrees of granitisation and anatexis have been described (Zagorchev, 1995; Zagorchev et al., 2015). Incipient metatexis (Fig. $6 a$ ) began with formation 

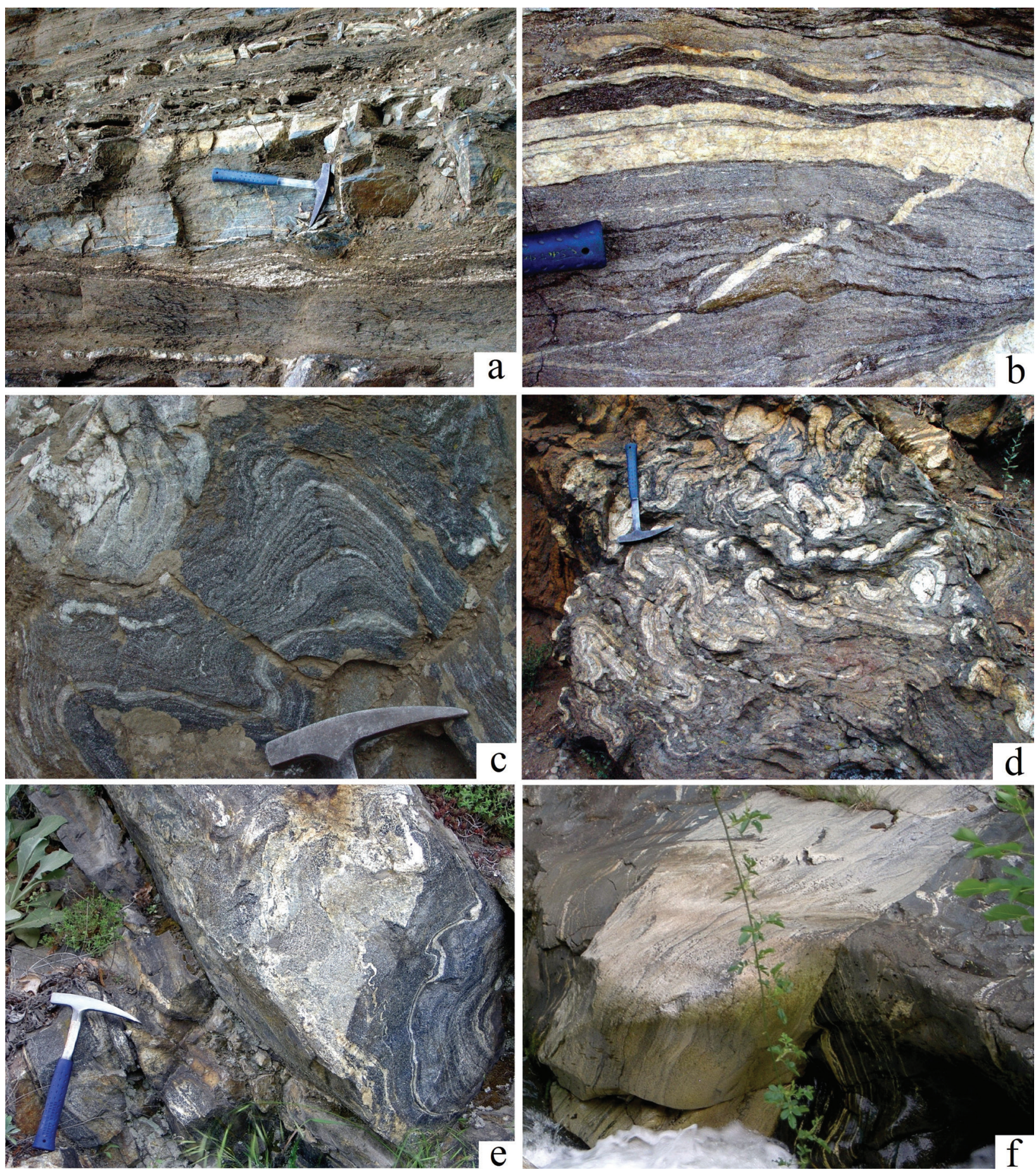

Fig. 6. Amphibolites and gneisses in different stages of anatexis. Northernmost (Krupnik) area of the Pirin subunit, road between the villages Sushitsa and Polena. $a, b$ ) incipient metatexis and late aplite-pegmatite veins; $c$ ) folded migmatites with different degree of metatexis, and nebulitization and diatexis at the left top; $d$ ) strongly folded ptygmatites; $e$ ) folded migmatitic amphibolites with nebulitization and diatexis (left side); $f$ ) diatexite intruding migmatized amphibolites. Detailed description in Zagorchev et al. (2015).

of bead-like quartzo-feldspathic lensoid bodies along the foliation. They gradually join in foliation-parallel veins of aplitic or granitic composition, thus forming a mature stromatitic structure (Fig. 5a-e; Fig. $6 c, d$ ). Some of the earlier foliation-parallel veins developed a superimposed foliation and became indistinguishable from quartzo-feldspathic gneisses that had derived from protolithic arkosic beds. Furthermore, the ductility of whole volumes of stromatitic migmatites dramatically increases, and two or three sets of pro- 
nounced interfering folds were formed, sometimes even leaving the impression of irregular and almost chaotic flow with formation of ptygmatic structure (Zagorchev, 1995). Amphibolites were often subject of irregular flake-like formation of anatectic material that anastomosed and formed diktyonitic structures. Influx of silica and alkali-bearing fluids transformed gneisses and even amphibolites into irregular nebulitic bodies with transitions to the host rocks (Fig. $5 c, d$ ). These bodies were sometimes subject of diatectic melting and may even have been mobilised and intruded into the host stromatic and/or nebulitic migmatites (Fig. 5f).

The above-described rock section has been correlated (Zagorčev et al., 1971; Zidarov et al., 1974; Zagorčev, 1994a, 1995) with the Chepelare Varied Formation, the lowermost formation of the Rupchos Group of the Rhodopian Supergroup (Kozhoukharov, 1984). Milovanov et al. (2009) referred these rocks to the introduced by them Predela complex, with a type section situated in the southernmost parts of the Rila Mountain. Although similar in composition, the outcrops of the "Predela complex" in their type area correlate (Marinova and Zagorčev, 1990, 1993) with the uppermost part of the Rupchos Group, the Vacha Varied Formation.

The whole section is intersected by foliation-parallel and cross-cutting bodies and dykes of porphyric (Krupnik) granite, from dykes of quartz-monzonites to granites related to the North Pirin (Dautov, Kresna) granitoid pluton, and of subvolcanic trachyandesites to trachydacites that belong to the Padesh-Breznitsa magmatotectonic (dyke) zone trending NW-SE (Zagorčev et al., 1971; Zagorčev, 1971).

A thin ribbon of granitised rocks of the Rupchos Group crops out as a discontinuous septum between the Krupnik and North Pirin (Kresna) granite plutons. The road E79 crosses the septum south of the northern entrance of the Kresna Gorge where different types of nebulites (passing into diatexites) formed after biotite gneisses and amphibolites (Fig. 7) have been observed (Zagorchev, 1995; Zagorchev et al., 2016). This ribbon is traced at a distance of several kilometres along the western contact of the Kresna pluton and has a thickness of a few hundred meters. It consists of biotite gneisses with amphibolite layers and rarely with marble layers and lenses. These rocks were subject of intense granitisation (nebulitisation) at a distance of more than $1.5 \mathrm{~km}$ (Zagorčev et al., 1971; Marinova and Zagorčev, 1990; Zagorčev, 1994a, 1995), and in the northern part of the septum they have recently been erroneously mapped as granites of the Krupnik pluton (Milovanov et al., 2009). Gneisses and amphibolites with a clear foliation and stromatic structure, and often with boudinaged amphibolite layers, were transformed into nebulites, with a ghost foliation, and passed into diatexites. Boudinaged amphibolite interlayers are transformed into lenses of hornblende-biotite gneisses (Fig. $7 a, c, d$ ). These lenses rotated at places and obtained a new parallel orientation within the granite-like nebulite. Aplitoid material with irregular diffuse boundaries was often formed, with nests of strongly transformed mafic minerals (garnet?, hornblende?). Diatectic anatexis pre-dated the intrusion of the Krupnik pluton, as witnessed by the crossing of diatexites by dykes of the porphyric Krupnik granite (Fig. 7e) with chilled 2-5 mm thick aplitic rims along the endocontacts (Zagorchev, 1995; Zagorchev et al., 2012).

A third ribbon of Rhodopian metamorphics crops out along the main faults of the Struma fault zone southeast of the Kresna Gorge and northeast of the town of Kresna. It is built up of biotite gneisses and amphibolites with a few marbles. They have been correlated with the Rupchos Group (Marinova and Zagorčev, 1990), although the restricted area of the exposures and the considerable brecciation due to Alpine brittle tectonics gives no clues for the attribution to the lower (Chepelare) or the upper (Vacha) Varied Formation of this group. Milovanov et al. (2009) referred these rocks again to the newly introduced by them Predela complex.

\section{Metamorphic rocks in the Sinanitsa area (area 2)}

These rocks are enclosed between the Palaeogene North Pirin and Central Pirin granite plutons and form an irregular area elongated in NNE-SSW direction. The backbone of the area (Fig. 2) is the Sinanitsa anticline (Zagorčev et al., 1974). The area is limited to the north by the Predela fault and to the south by the West-Pirin fault zone.

The metamorphic rocks of the Sinanitsa area consist of two principal lithostratigraphic units separated by a transitional formation. The lower unit comprises muscovite and two-mica quartzo-feldspathic gneisses, banded biotite gneisses, and sillimanite-cordierite and sillimanite gneisses. In some places, the gneisses are garnet-bearing. The rocks build up the core of the Sinanitsa anticline. They have been designated by Boyadjiev (1959) as the Vihren Formation, and this name (Vihren gneisses) was restored by Milovanov et al. (2009). Zidarov et al. (1974) and Marinova and Zagorčev $(1990,1993)$ correlated them with the Boykovo and Bachkovo formations (Kozhoukharov, 1984) of the Central Rhodopes, emphasising the impossibility to differentiate the two formations in view of the strong granitisation and migmatisation, which are believed to be effects of the saturation with huge amounts of granite magmas in their vicinity. The upper unit consists of massive or banded calcitic and dolomitic marbles (marble formation), locally interlayered with calcareous schists or biotite gneisses and schists. The unit has been correlated with the Dobrostan Marble Formation. Each of the two units has a thickness of more than 800-1000 m. A 50-300 m thick alternation of biotite gneisses and schists, two-mica quartzo-feldspathic gneisses, garnet-biotite schists, calcareous schists, calciphyres, pyroxene gneisses, 

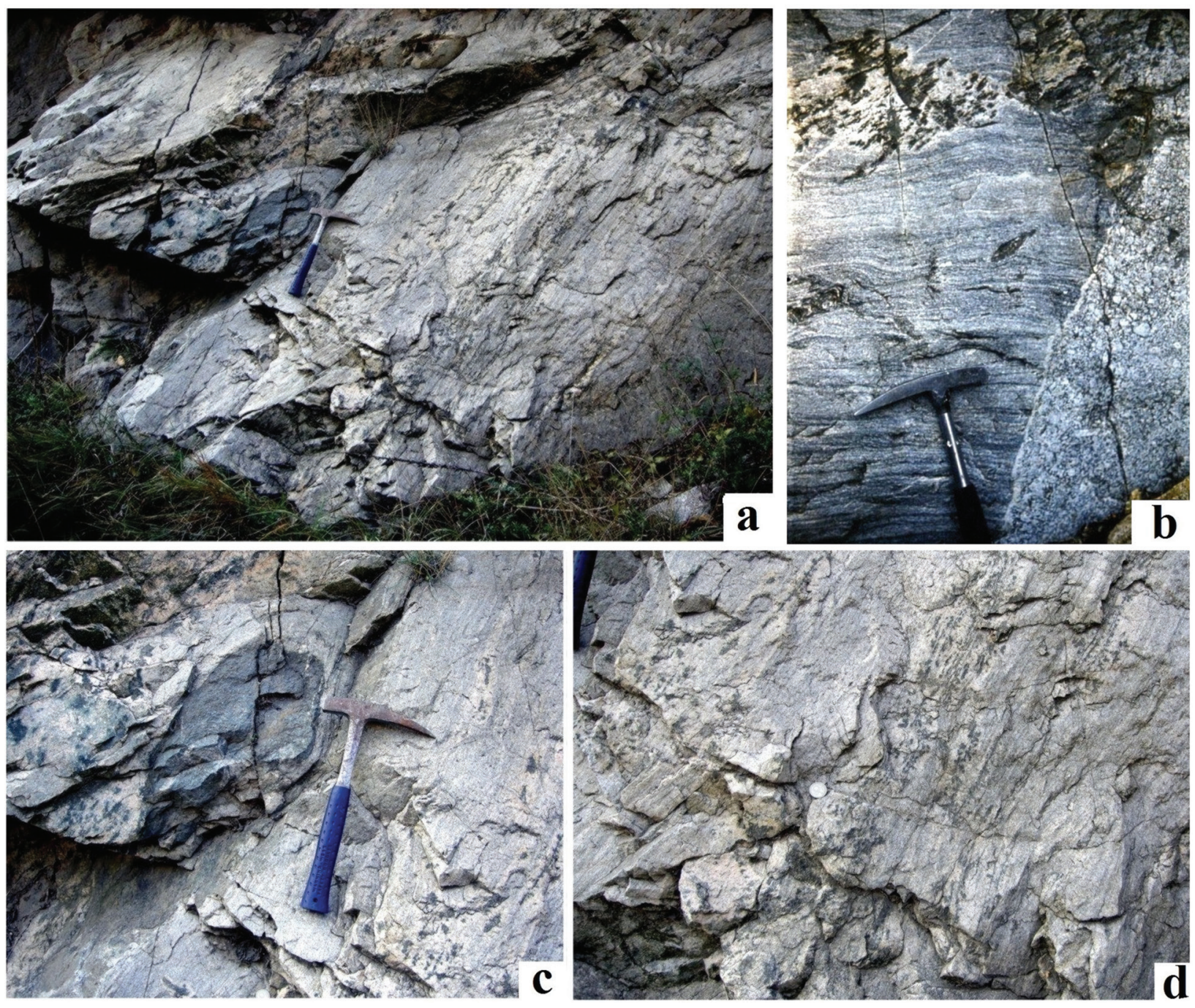

Fig. 7. Granitised gneisses and amphibolites in the septum between the Triassic Krupnik pluton and the Oligocene Kresna (North Pirin, Dautov) pluton. Northern part of the Kresna Gorge, road cuttings of road E-79. a) general view of the sampling site; $b$ ) granitised gneiss with amphibolite interbeds crosscut by dyke of porphyric Krupnik granite with thin chilled margins of fine-grained aplitic granite; $c, d$ ) granitised gneisses with different degree of nebulitization and diatexis, with relicts of granitised amphibolite boudin (details from $a$ ).

and thin marble and amphibolite beds is exposed as a transitional unit between the two major formations and has been called Banderitsa Formation (Boyadjiev, 1959) or Banderitsa gneisses (Milovanov et al., 2009). Zidarov et al. (1974) and Zagorchev (1995) correlated this transitional formation with the Lukovitsa Varied Formation of the Central Rhodopes (Kozhoukharov, 1984). Milovanov et al. (2009) grouped all three formations (Vihren gneisses, Banderitsa gneisses, and the marble formation) into a Sinanitsa complex. According to Zagorchev (2008), the lower unit belongs to a metapsammitic Bachkovo complex, whereas the Lukovitsa Varied Formation (Banderitsa gneisses) and Dobrostan Marble Formation belong to the Ase- novgrad complex. The protoliths of the two complexes marked a sedimentation cycle of transgressive psammites through a thin transitional formation of pelitic and carbonaceous sediments to a thick formation of limestones and dolostones. These rocks have undergone amphibolite-facies metamorphism during several metamorphic events and have also been intruded by at least two generations of granite and aplite veins. The first generation consists mostly of foliation-parallel or oblique veins of granite and aplite of metatectic character. Besides this migmatisation, nebulites have also been observed, some of them being very similar to the nebulites within the septum of the Krupnik area. 


\section{Metamorphic rocks along the western slopes of Pirin (Lilyanovo area 3)}

The section to the east of the villages of Lilyanovo and Lyubovka (area 3) has been referred (Zidarov et al., 1974; Zagorčev and Dinkova, 1989) to the "middle varied formation" (Vacha Varied Formation). It is parallelised with the "amphibolite threshold" within the narrow horst SE of the Simitli graben and with the Vacha Varied Formation from Southern Pirin, i.e., the strongly fractured rocks around the east and to the south of the village of Pirin, all attributed later (Klimov et al., 2009) to the Belyovo metamorphic complex. Milovanov et al. (2009) referred this section to their Predela metamorphic complex. All these local names correspond in fact to the Rupchos Group (complex) of the Rhodopian Supergroup (supercomplex) or (in the case of our area 3), to the Vacha Varied Formation. The section has a thickness of more than $400 \mathrm{~m}$ and consists (Zidarov et al., 1974) of amphibolites, hornblende-biotite, biotite and two-mica gneisses, garnet-clinozoisite-hornblende, hornblende-biotite and biotite schists, and rarely quartzo-feldspathic gneisses and marbles. Orthoamphibolites, metabasites, and ultramafics have also been reported and later studied in detail (Machev and Veit, 2001). Metapelites (garnet-staurolite-kyanite-biotite schists) were studied by Machev et al. (2005) and Machev and Hecht (2008). The section is overturned over the thinned Boykovo, Bachkovo, and Lukovitsa formations and over the recumbent Shashka syncline (Zagorčev et al., 1974; Zagorčev, 1994a) built up of the marbles of the Dobrostan Formation, the thickness of these formations being significantly reduced due to synmetamorphic shearing (Zagorčev et al., 1974; Zagorčev, 1994a) or thrusting (Milovanov et al., 2009) along a shear zone.

\section{Metamorphic rocks of Southern Pirin, Stargach and Slavyanka (area 4)}

The structure of these rocks has been formed as a result of multiple deformations (Zagorčev et al., 1974; Zagorčev, 1994a). Whereas the Stargach Mountain represents a normal antiform very similar in composition and structure to the Sinanitsa anticline, the domal structure of Southern Pirin and Slavyanka (Alibotush, Orvilos) is due to the intrusion of the Oligocene South Pirin (Teshovo) granite pluton and has been superimposed over an older structure built at least in three deformational phases (Zagorčev, 1981, 1994a). The metamorphic formations in the best-exposed western limb of the Teshovo dome are in an overturned position, whereas the eastern limb is strongly reworked by the faults of the East Pirin fault zone. The section was studied in details during the geological mapping in scales 1:25 000 and 1:50 000 (Zidarov et al., 1974; Zagorčev and Dinkova, 1989, 1991; Kozhoukharov and Marinova, 1991; Klimov et al., 2009). The re- stored section consists of the following lithostratigraphic units (from the bottom of the normalised section towards the top; Fig. 8).

A formation of biotite plagiogneisses (Zidarov et $a l ., 1974)$ crops out in the core of the Petrovo anticline and was intruded by the Spanchevo granite. It has a monotonous composition, very rarely with local thin interbeds of hornblende-biotite gneisses, amphibolites, and marbles. The formation has been correlated (Kozhoukharov and Marinova, 1991) with the Bogutevo Formation of the Central Rhodopes (Kozhoukharov, 1984).

A highly varied alternation ("middle varied formation", Zidarov et al., 1974) of hornblende-biotite, biotite and two-mica gneisses and schists, quartzofeldspathic gneisses, quartzites, sillimanite-garnet and garnet-bearing biotite schists, kyanite gneisses and schists, amphibolites, marbles, calciphyres is present in the two flanks of the Petrovo anticline. The western limb was thinned out and disrupted by the West Pirin fault zone and was subject of diaphthoresis during the thrusting along the Strimon Thrust. The eastern limb has an apparent thickness of 900-1200 m, the individual amphibolite layers reaching several tens of metres and the marble ones, up to $200 \mathrm{~m}$. Orthoamphibolites, metapyroxenites, and metaperidotites are present as foliation-parallel rootless bodies. The formation has been correlated (Kozhoukharov and Marinova, 1991) with the Vacha Varied Formation. Klimov et al. (2009) referred the formation (together with the formation of the biotite plagiogneisses) to the introduced by them Belyovo metamorphic complex. Zidarov et al. (1974) made a thorough study of the formation in several sections and concluded that its protolith had been a flysch sequence with basic volcanism.

The next formations have been designated (Zidarov et al., 1974; Kozhoukharov and Marinova, 1991) as formation of biotite and two-mica banded gneisses (Boykovo Formation) and formation of leptitoid gneisses (Bachkovo Formation). The term "leptitoid gneisses", "aplitoid gneisses" or "leptynites" ("leptinites") refers to very leucocratic, fine-grained to medium-grained quartzo-feldspathic gneisses (the sum of quartz and feldspars is about $85-90 \%$ ) with a very low (usually less than $10 \%$ ) mica content, often with some garnet. The thickness is summarised at $400 \mathrm{~m}$ to about $1000 \mathrm{~m}$. Their protoliths may be (arkosic) sandstones, eventually marking the beginning of a new sedimentary cycle (Zagorchev, 2008). Other researchers (e.g., Machev and Ovtcharova, 2008; Klimov et al., 2009) considered these rocks as Hercynian metagranites (Kriva-reka orthogneisses; porphyroclastic metagranitoids) without explaining their constant position in the sections of the metamorphic complexes throughout the Rhodopes (see Kozhoukharov, 1984, 1986).

The upper varied formation (Lukovitsa Varied Formation; Kozhoukharov and Marinova, 1991) is represented by an alternation of biotite, hornblende-biotite, garnet-biotite and quartzo-feldspathic gneisses, biotite 

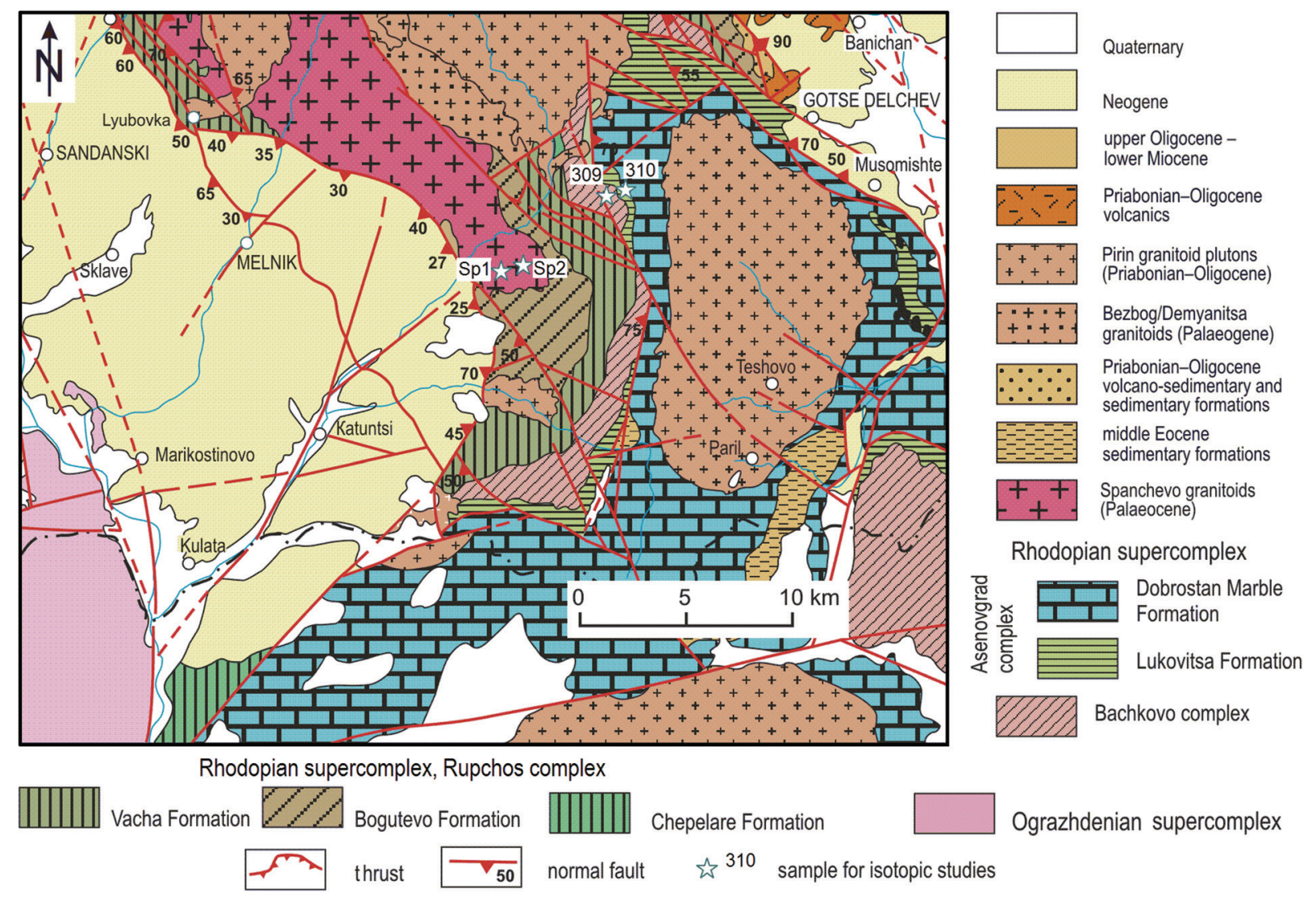

Ograzhdenian supercomplex

Fig. 8. Geological map of the southern area of the Pirin Subunit (after Zidarov et al., 1974, and Zagorchev et al., 2012).

schists (often graphite- and/or garnet-bearing), amphibolites, calcareous schists, and marbles (Fig. 9a,b). The thickness is restricted to about $300 \mathrm{~m}$ and the formation has a transitional character (Zidarov et al., 1974) towards the next (and the last one in Pirin) Dobrostan Marble Formation. The thickness of the latter probably exceeds $1000 \mathrm{~m}$. It consists of three members built up correspondingly of: (1) grey to whitish banded or massive marbles interlayered with calcareous schists and biotite schists; (2) medium- to fine-grained graphite-bearing marbles and dolomitic marbles; and (3) fine-grained dolomitic marbles. Kozhoukharov and Konzalova (1990) found in the marbles of the Dobrostan Formation both in Southern and in Northern Pirin microphytofossils belonging to typical Neoproterozoic taxa, and similar findings have been reported (Kozhoukharov, 1994) in the southern subunits of the Pirin-Pangaion Unit on Greek territories.

The "Kriva-reka orthogneisses", the upper varied formation (Lukovitsa Formation) and the marble formation (Dobrostan Formation) were regarded by Klimov et al. (2009) as an Orelek metamorphic complex. It is correlatable with the Bachkovo-Asenovgrad complex of Zagorchev $(2008,2014)$.

\section{Obidim area (area 5)}

The metamorphic rocks along the eastern rim of the Pirin Mountain and along the Mesta River Valley are an alternation of hornblende-biotite, biotite and two-mica migmatitic para- and orthogneisses, garnet- and kyanite-bearing two-mica schists (metapelites), amphibolites, and bodies of metagabbroids and metaultrabasics (Zidarov et al., 1974; Marinova and Katzkov, 1990; Sarov et al., 2010, 2011; Peytcheva et al., 2009). The outcrops are scarce and discontinuous due to intense tectonic reworking and to the numerous Palaeogene volcanic and subvolcanic bodies and postsedimentation grabens filled in by relicts of the Palaeogene sedimentary cover. Sarov et al. $(2010,2011)$ and Peytcheva et al. (2009) referred these rocks to an Obidim lithotectonic unit and envisaged a parallelisation with the Ograzhdenian supercomplex west of the Strymon "detachment" (respectively, overthrust). They mentioned also the presence of K-feldspar porphyric metagranites. We follow the initial identification of these rocks (Zidarov et al., 1974; Marinova and Katzkov, 1990) as belonging to the Rupchos Group and, mainly, to the Bogutevo Formation. 


\section{Metamorphic conditions and processes}

The prograde regional metamorphism of the Rhodopian metamorphic supercomplex has been referred to the amphibolite facies, with variations in the highest parts of the section in the Northern Rhodopes, to the highergrade greenschist (or epidote-amphibolite) facies (see Vergilov et al., 1963). Greenschist facies metamorphism has usually been related to superimposed late retrogressive (diaphthoresis) events. These attributions
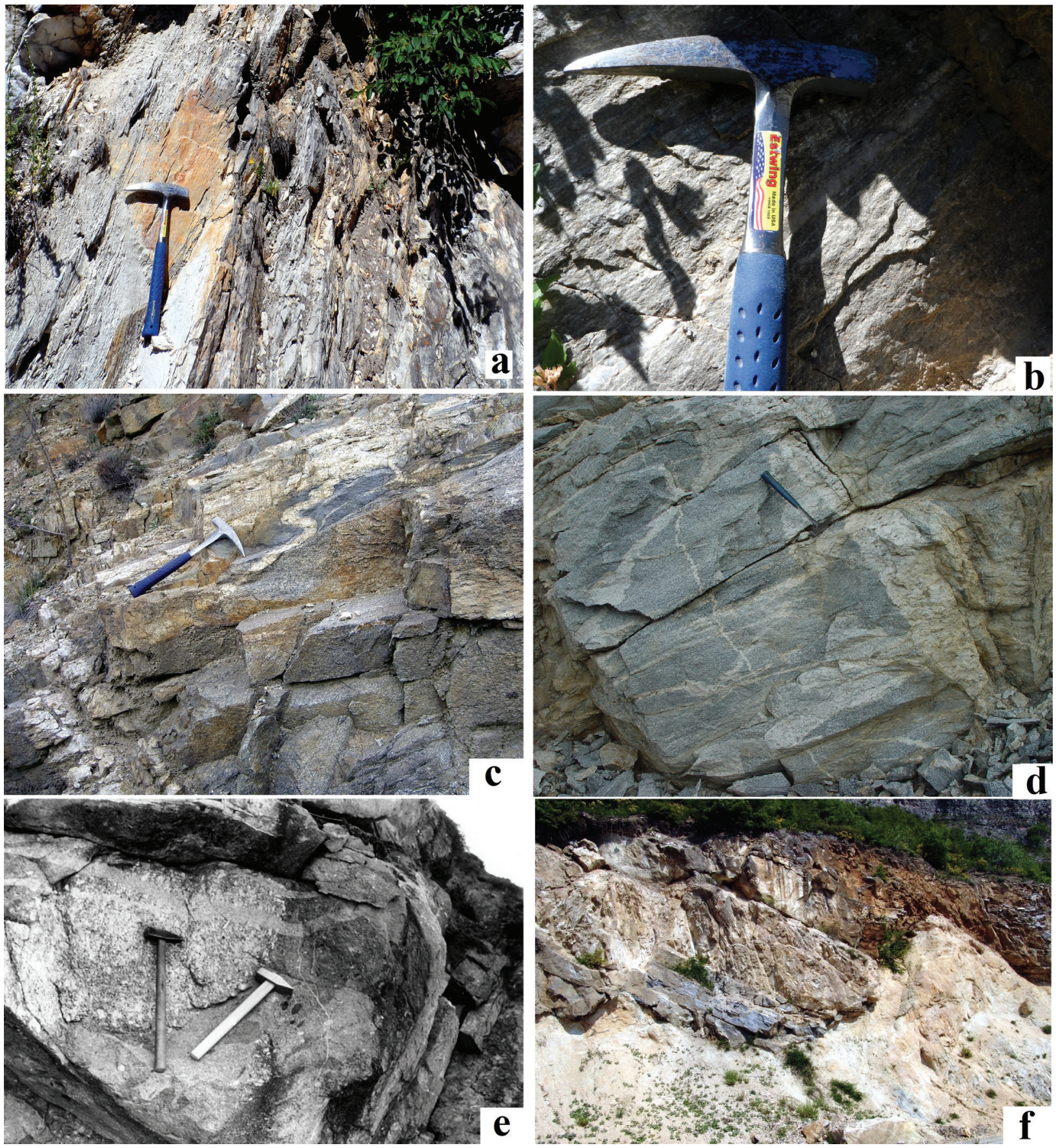

Fig. 9. Outcrops in the southern Pirin area. $a, b$ ) biotite metapelites and gneisses with amphibolite and marble interlayers of Lukovitsa Formation, along the same road, near the boundary with Dobrostan Marble Formation, sampling site of sample 310; $c, d)$ Spanchevo granite with skialiths of amphibolite and gneiss with different degree of resorption, cross cut by folded aplites and superimposed foliation, along the same road near the crossing to Pirin Village; $e$ ) xenolith from the porphyric Bezbog granite within the Central Pirin granodiorite with mafic enclaves, road cuttings along the road from Pirin Village towards the mountain hut Pirin, platy parallelism in the two granite types is marked with the handles of the two hammers; $f$ ) Dobrostan Marble Formation intruded by the Oligocene Teshovo (South Pirin) granite at Popovi livadi locality. 
have been made exclusively on the presence of indicative mineral parageneses. Kozhoukharov et al. (1988, and many earlier publications) argued for a polymetamorphic character also related (e.g., Zagorčev et al., 1974; Zidarov et al., 1974; Zagorčev, 1994a) to different deformation phases during the Cadomian, Hercynian, and Alpine cycles. Burg et al. (1996) pleaded for a single-cycle (Alpine, most probably Late Cretaceous) metamorphism of Phanerozoic sedimentary and igneous protoliths. Kozhoukharova (1980) first found and published the presence of eclogite bodies within the Rhodopian metamorphic complex. Eclogites have later been described in different parts of the Rhodope edifice, the Pirin-Pangaion Unit inclusive (see Machev et al., 2005; Machev and Hecht, 2008; Janak et al., 2011), as well as relicts from granulite facies parageneses (Machev and Hecht, 2008; Janak et al., 2011). However, the use of conventional geothermobarometers in such polymetamorphic terrains meets considerable difficulties, and they are even inapplicable because most of the minerals are in disequilibrium (Machev and Hecht, 2008). The information obtained is very scarce, and even scarcer and more insufficient in the Pirin Subunit, where it concerns three rock types taken from three different structural and petrological settings, and yields different apparent ages. Therefore, the results of these studies (Fig. 10) are imprecise and may serve only as indicative of the

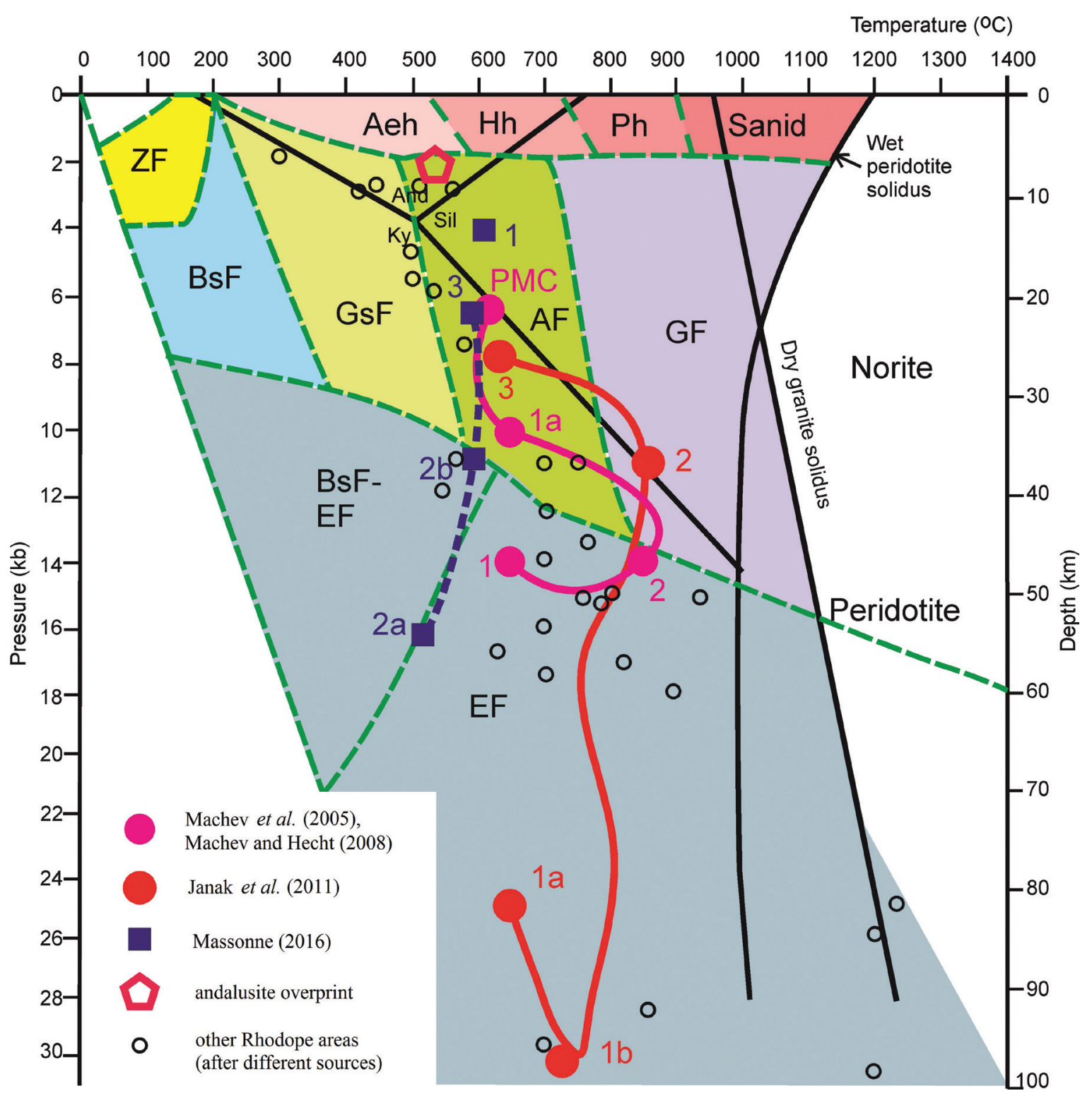

Fig. 10. P-T diagram for the metamorphic conditions and P-T paths in the Pirin subunit. Data of Machev et al. (2005), Machev and Hecht (2008), Janak et al. (2011), and Massonne (2016). Metamorphic facies fields adapted after Winter (2001), Maruyama and Okamoto (2007), Bucher and Grapes (2011), Imperial College London (2013). 
thermobaric environments expected. Other difficulties and uncertainties come from the flaws of the thermobarometers used and from the considerable differences (sometimes, of more than $100-150{ }^{\circ} \mathrm{C}$ and of several kbar) in the determination of the boundaries between the facies fields (see Winter, 2001, 2011; Bucher and Frei, 1999; Bucher and Grapes, 2011; Okamoto and Maruyama, 1999; Imperial College London, 2013).

The thermobarometers used are described in different details in the studies discussed. Several classical thermobarometers have been used in accordance to the different mineral assemblages analysed.

The P-T evolution of the Rupchos metapelites in the Lilyanovo area (area 3) has been studied by Machev et al. (2005) and Machev and Hecht (2008). The rocks contain three equilibrium assemblages: (1) garnet + staurolite + kyanite + quartz; (2) spinel + plagioclase + sillimanite + quartz + orthopyroxene; (3) biotite + white mica (muscovite) + andalusite + chlorite + quartz. The authors cited also emphasised the resorption and replacement of the minerals of the first assemblage by "secondary" minerals: the coarse garnet porphyroblasts by aggregates of biotite (or chlorite) and white mica (sericite); the kyanite by finegrained aggregates; and the staurolite by sericite. Typical for the rocks are biotite + fibrolite intergrowths and fibrolite formation around the andalusite porphyroblasts. The $\mathrm{P}-\mathrm{T}$ values $\left(650^{\circ} \mathrm{C}\right.$ and $\left.13-15 \mathrm{kbar}\right)$ for the assemblage (1) correspond to the stability field of staurolite. On the presence of anorthite-spinel coronas around the kyanite, granulite-facies overprint at more than $850{ }^{\circ} \mathrm{C}$ is assumed for assemblage (2). Machev et al. (2005) inferred a lowest value for the first (?) assemblage, also of $650{ }^{\circ} \mathrm{C}$ and $10 \mathrm{kbar}$, and cited a measurement by conventional garnet-biotite geothermobarometer for the "Pirin metamorphic complex below the Strymon Detachment" (presumably from the "Sinanitsa complex" of Milovanov et al., 2010, or the Lukovitsa Formation; Sinanitsa area) of $610-640{ }^{\circ} \mathrm{C}$ at 6 kbar. All uncertainties of the studies cited make the data points and the hypothetic $\mathrm{P}-\mathrm{T}$ path shown in Fig. 10 questionable. The P-T conditions of assemblage (3) have not been estimated, because no suitable geothermobarometers exist. However, the presence of andalusite (known since the first geological mapping; see Boyadjiev, 1959) is related to very low-P conditions of the order of 2-3 kbar and temperatures of the order of $500{ }^{\circ} \mathrm{C}$. This assemblage has been related (e.g., Boyadjiev, 1959; Zidarov et al., 1974) with the intrusion of the Alpine granite plutons.

The metamorphic conditions within the metapelites of the Lukovitsa Formation of Southern Pirin (area 4) have recently been studied by Massonne (2016). The mineral composition of the metapelites includes white mica, garnet, plagioclase, quartz, biotite, andalusite, ilmenite, rutile, zircon, apatite, monazite, and barite. The attention has been focused on the large zonal garnet crystals and the associated mineral inclusions, as well as on the white mica. The main subjects are the garnet core and garnet mantle, which differ in composition. The $\mathrm{P}-\mathrm{T}$ conditions for the formation of the core are roughly estimated at low pressure of $3-5 \mathrm{~kb}$ and high temperature exceeding $600{ }^{\circ} \mathrm{C}$. The conditions of the second (garnet mantle) phase have been studied with more certainty and describe a following $\mathrm{P}-\mathrm{T}$ path (Massonne, 2016): (2a) $\mathrm{P}=10-16 \mathrm{kbar}, \mathrm{T}=$ 490-520 ${ }^{\circ} \mathrm{C}$; (2b) $\mathrm{P}=9.5-12 \mathrm{kbar}, \mathrm{T}=555-580{ }^{\circ} \mathrm{C}$. "Using the above $\mathrm{P}-\mathrm{T}$ constraints, a clockwise $\mathrm{P}-\mathrm{T}$ loop for the formation of the garnet mantle can be reliably reconstructed. This loop starts at $16 \mathrm{kbar}$ and $500{ }^{\circ} \mathrm{C}$, passes through $\mathrm{P}-\mathrm{T}$ conditions of $14 \mathrm{kbar}$ and $550{ }^{\circ} \mathrm{C}$, and ends at $10 \mathrm{kbar}$ and $570{ }^{\circ} \mathrm{C}$ " (Massonne, 2016); (3) An incomplete rim domain of unoriented (random) muscovite flakes around the garnet grains is further described, its $\mathrm{P}-\mathrm{T}$ conditions being estimated roughly at about $6 \mathrm{kbar}$ and temperatures near $600{ }^{\circ} \mathrm{C}$.

The geothermobarometric studies (Janak et al., 2011) within the Rupchos complex in the Obidim area (area 5; Obidim lithotectonic unit, see Sarov et al., $2008,2010)$ used the high-pressure (HP) mineral assemblages within a kyanite eclogite found as a lens ("boudin") within a large amphibolite body. The minerals studied are garnet, kyanite, amphibole, clinopyroxene, omphacite, phengite, plagioclase, spinel, corundum, staurolite, zoisite, and chlorite. They belong to several mineral parageneses, formed in different thermobaric conditions. Therefore, the P-T conditions of studied mineral pairs have been based upon observations and assumptions on the textural relationships, phase equilibrium modelling, and geothermobarometry. The first HP mineral assemblage consists of garnet + omphacite + kyanite + phengite \pm amphibole \pm zoisite + quartz + rutile. This paragenesis has been overprinted by later lower-pressure metamorphic events. The results obtained are as follows: (1) peak $\mathrm{P}$ conditions are based upon a garnet-phengite-clinopyroxene-kyanite-quartz/coesite geothermobarometer, with uncertainty limits of $\pm 65^{\circ} \mathrm{C}$ and $\pm 0.32 \mathrm{GPa}$ and are estimated at $2.7-3.1 \mathrm{GPa}$ at $700-750{ }^{\circ} \mathrm{C}$, or (by conventional geothermobarometry) at $2.83 \mathrm{GPa}$ at $712{ }^{\circ} \mathrm{C}$ and $2.98 \mathrm{GPa}$ at $700{ }^{\circ} \mathrm{C}$; (2) formation of spinel, corundum, and anorthite-rich plagioclase at the expense of kyanite, omphacite, and zoisite within $\mathrm{P}-\mathrm{T}$ conditions of ca $1.1 \mathrm{GPa}$ and $800-850{ }^{\circ} \mathrm{C}$; (3) formation of kelyphitic amphibole-plagioclase rims around garnet at ca $0.8 \mathrm{GPa}$ and $650{ }^{\circ} \mathrm{C}$. The corresponding $\mathrm{P}-\mathrm{T}$ evolution path (Fig. 10) is related (Janak et al., 2011) to exhumation from the high-pressure to ultrahigh-pressure conditions (eclogite facies) via granulite facies to amphibolite facies conditions and has been dated (Peytcheva et al., 2009) as Palaeozoic.

Although loaded with some uncertainties, the results published enable some comparisons and conclusions. The results as published by the corresponding researchers are shown in Fig. 10.

The amphibolite-facies metamorphic conditions for all three areas are similar, and the corresponding figurative points deviate around ca $\mathrm{T}=550-600^{\circ} \mathrm{C}$ and 
$\mathrm{P}=6.5-8$ kbar. Such conditions have been reached by the rocks studied more than once since (even in conditions of one-cycle hypothesis) pelitic protoliths were buried to these $\mathrm{P}-\mathrm{T}$ depths from near-surface (very low-grade metamorphism) via the greenschistfacies field. Continuing burial to eclogite-facies depths reached probably lower amphibolite-facies to upper eclogite-facies field, i.e., pressures of around 10-12 kbar and temperatures of $500{ }^{\circ} \mathrm{C}$ (Massonne, 2016) to $700{ }^{\circ} \mathrm{C}$. In some cases, a granulite-facies overprint (Machev and Hecht, 2008; Janak et al., 2011) could also be possible. During exhumation, the $\mathrm{P}-\mathrm{T}$ path would pass again through the amphibolitefacies field with maintaining higher temperatures than the prograde part, and with amphibolite-facies overprint. The time of this metamorphism in all three areas studied is probably Palaeozoic (see Janak et al., 2011). The formation of andalusite-bearing parageneses is related to the very late (Palaeogene) igneous activity, probably to the late Eocene-early Oligocene granite intrusions that produced at their contacts also biotite-, amphibole-, and pyroxene-bearing scarns and hornfelses (Dimitrov, 1957; Boyadjiev, 1959, and many later publications).

\section{Granitoids}

\section{General information}

The granitoid rocks have been known in the Pirin Mts since the first geological studies in this region. They have been attributed (Dimitrov, 1959, and references therein) to the group of the Hercynian South Bulgarian granites. The first attempts to distinguish between granitoid bodies of different compositions and ages were made by Boyadjiev (1959). He separated from the South Bulgarian granites the so-called "granites of Pirin type" and suggested for them an Alpine age. Further on, Zagorčev et al. (1974) and Slavov et al. (1976) stressed on the petrological and structural features of the granitoid bodies and distinguished the following plutons or pluton groups: (1) Spanchevo, Bozhdovo, and Zmeyski plutons of a possible late Precambrian or Palaeozoic age; (2) Krupnik and Bezbog plutons attributed to the Palaeozoic (Hercynian); (3) Alpine (probably Late Cretaceous) plutons of Pirin type: North Pirin (Dautov, Kresna), Breznitsa, Central Pirin, and South Pirin (Teshovo) plutons. Problems of the relations between the equigranular and the porphyroid granitoids were discussed by the above-cited authors and by Dimitrova and Sarafova (1968), Dimitrova (1971), and Georgiev (1993). Potassium-argon studies were made and summarised by Boyadjiev and Lilov $(1972,1976)$. The first geochronological studies (Amov et al., 1982; Arnaudov and Arnaudova, $1982 ; \mathrm{Pb} / \mathrm{Pb}$ method) suggested a Palaeogene age for the Central Pirin pluton (and for the other plutons of the Pirin type), later (Zagorčev et al., 1987) partially confirmed by the Rb-Sr method. During the last decade, considerable progress has been made by extensive U-Pb studies on zircons (Milovanov et al., 2009, 2010; Jahn-Awe et al., 2010; Filipov and Marchev, 2011, 2012; Filipov et al., 2012, 2014; Georgiev et al., 2012; Marchev et al., 2013; Zagorchev et al., 2011, 2012, 2014). These studies establish a basis for dating the individual granitoid bodies and their complexes, and the timing of the granitoid activity enables dating of some of the important deformation events.

\section{Krupnik pluton}

The Krupnik granite pluton (Zagorčev et al., 1971; Marinova and Zagorčev, 1990, 1993; Zagorčev, 1994a, 1995; Machev and Klain, 2000; Milovanov et al., 2009, 2010) is a small body cropping out within an area of about $25 \mathrm{~km}^{2}$ and elongated in NNE-SSW direction. The body has an irregular sill-like shape, dips west, and has two sill-like and several dyke apophyses. The contacts of the pluton with the host metamorphics (attributed to the Chepelare Formation, Rupchos Group of the Rhodopian Supergroup) are usually sharp, and the granite includes angular xenoliths with sharp contacts. However, "transitional" granitisation boundaries have also been reported. The Krupnik pluton is built up of granodiorite to granite and quartzmonzonite. Numerous xenoliths in different degrees of disintegration and resorption are present (Fig. 5d-f). The granitoids are coarse-grained to porphyric, with abundant K-feldspar phenocrysts and a typical granitic structure. The K-feldspar is a microperthitic orthoclase. Plagioclase is of oligoclase composition, in zoned euhedral lamellar grains. Myrmekites develop along the contacts. Biotite has an eastonite-siderophyllite composition. Quartz is in xenomorphic grains. Apatite, zircon, magnetite, xenotime, and allanite are the main accessories. The chemical composition of the rocks (Fig. 11) corresponds to high-K subalkaline calc-alkaline granite, quartz-monzonite, and granodiorite. They are peraluminous and markedly more alkaline than the Late Cretaceous granites (Kamenov et al., 1999) of the first phase of the West Rhodope batholith. On the A/CNK vs $\mathrm{SiO}_{2}$, they fall within the S-type field. The figurative points fall on the $\mathrm{Fe}^{*}$ vs $\mathrm{Si}$ diagram within the magnesian field, and the $\mathrm{MgO}$ values vary between $0.1 \%$ and $1.8 \%$. The petrochemical features of the Krupnik granites are very similar to these of the younger Kresna (Dautov) granite pluton (Machev and Klain, 2000; Zagorchev et al., 2012). The field of the Kresna granites almost coincides with the field of the Krupnik granites on the classification diagram. This similarity is probably due to the similar composition of the source rocks that underwent anatectic processes in Late Hercynian and in latest Eocene times.

\section{Spanchevo and Zmeyski granitoid plutons}

The Spanchevo pluton (Zagorchev et al. 1974; Slavov et al. 1976; Machev, 1993) is a small granitoid 

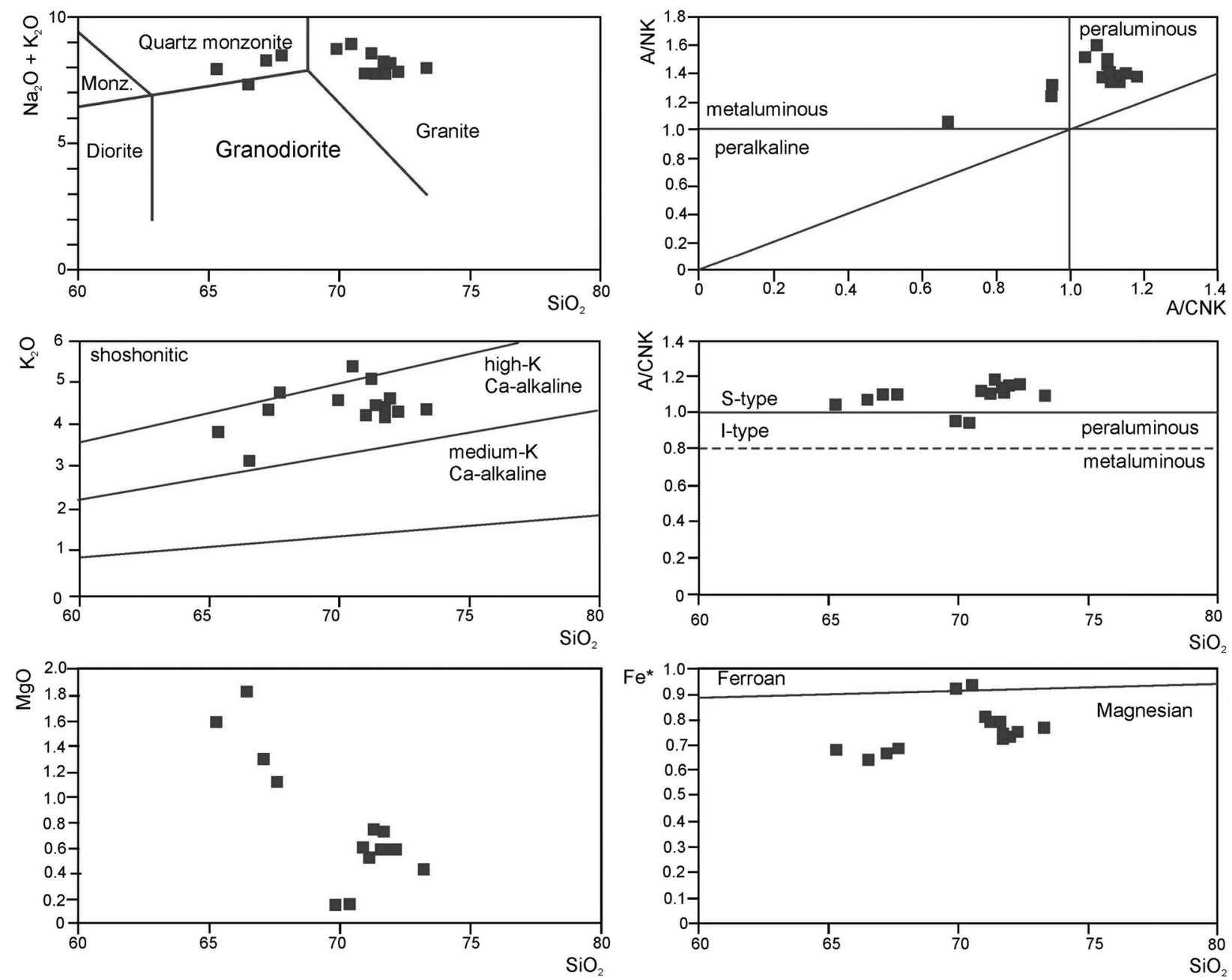

Fig. 11. Chemical data diagram for the Krupnik granite (after data of Slavov et al., 1974, and Machev and Klain (2000).

body intruded into the Rhodopian supercomplex in the southwest part of the Pirin subunit. The Spanchevo granitoids have previously been described (Boyadjiev, 1958) as granite-gneisses of the amphibolite-facies complex. The body is almost concordant and emits numerous foliation-parallel and cross-cutting apophyses. It is divided into two parts by the southwestern tip of the western (Spano Pole) dome of the Oligocene Central Pirin granitoid pluton. A small sill-like body of the same granite (Bozhdovo "pluton") is mapped NW of the main body. The Spanchevo pluton is intruded into the gneissic part (Bogutevo Formation) of the Rupchos Group (complex), and only at the southwestern periphery, within the varied, predominantly amphibolitic part (referred either to the Vacha or to the Chepelare Formation) of the same complex.

The Spanchevo granitoids (see data of Slavov et al. 1976; Boyadjiev, 1989; Machev, 1993) are coarsegrained biotite granites and plagiogranites with local variations to granodiorites and quartz-monzonites, with comparatively low compositional variability.
However, at some places, and especially in the peripheral parts, a compositional banded partitioning of the amount of biotite may be observed, and it can be related to the replacement of the "host" gneisses by granites via partial melting (anatexis). Numerous decimetric pegmatite and aplite dykes are present. They are situated either parallel to the banded structure or crosscutting or oblique to it. The superimposed schistosity usually inherits the banded structure and deforms the oblique and/or cross-cutting dykes into mesofolds with axial planes parallel to the schistosity (Fig. $9 c, d$ ).

The mineral composition is described herein following Machev (1993b). Plagioclase is oligoclaseandesine, often twinned, from $\mathrm{An}_{30-34}$ in the centre to $\mathrm{An}_{20-24}$ at the periphery. A late xenomorphous albite-oligoclase $\left(\mathrm{An}_{10-15}\right)$ develops together with late mirmekites. K-feldspars often build big endocrysts twinned following the Carlsbad law. In the groundmass, they are xenomorphic and range from orthoclase to maximal microcline. Biotites are close to the eastonite-siderophyllite series. Two quartz generations 
are observed, quartz I being present as inclusions in $\mathrm{K}$-feldspar, and quartz II participating in xenomorphic fine-grained late aggregates together with plagioclase II. The accessory minerals are allanite, zircon, apatite, sphene, and garnet.

The Spanchevo granitoids are high-K calc-alkaline granites to granodiorites (Fig. 12), mostly peraluminous, with $\mathrm{K}_{2} \mathrm{O}$ varying between $2.5 \%$ and $4.5 \%$. Magnesium oxide contents vary considerably (from $0.5 \%$ to $1.62 \%$ ), and the value of $\mathrm{Fe}^{*}$ is between 0.61 and 0.82 (entirely in the magnesian field).

Another granitoid pluton of the same age has been mapped and named (Zidarov et al., 1974; Zagorčev et al., 1974; Slavov et al., 1976; Zagorchev, 1995; see also Marinova and Katzkov, 1990; Katzkov and Marinova, 1992) as Zmeyski pluton (after the small river Zmiya Dere north of the village of Breznitsa). The relics of this pluton are preserved as a ribbon along the East-Pirin fault zone, and its area is followed from
Zmiya Dere in the south to the places between Bansko and Dobrinishte to the north. It is intruded into the rocks of the Bogutevo Formation. The Zmeyski granitoids have been regarded as being of Palaeozoic age, by analogy with the Spanchevo pluton (see Zagorčev et al., 1974; Slavov et al., 1976; Katzkov and Marinova, 1992), and being different from the Bezbog pluton (also considered as Palaeozoic), but this distinction had escaped the attention of later researchers (Sarov et al., 2010).

The Zmeyski granitoids are biotite and hornblende-biotite granites to granodiorites. They are coarse-grained or porphyric and rich in pegmatites and aplites, thus being similar to the rocks of the Spanchevo pluton (Slavov et al., 1976) by structure and mineral composition. However, they are intensely foliated and fractured due to the location within the East-Pirin fault zone (Dobrinishte magmatectonic zone, Breznitsa-Kremen shear zone, Obidim detach-
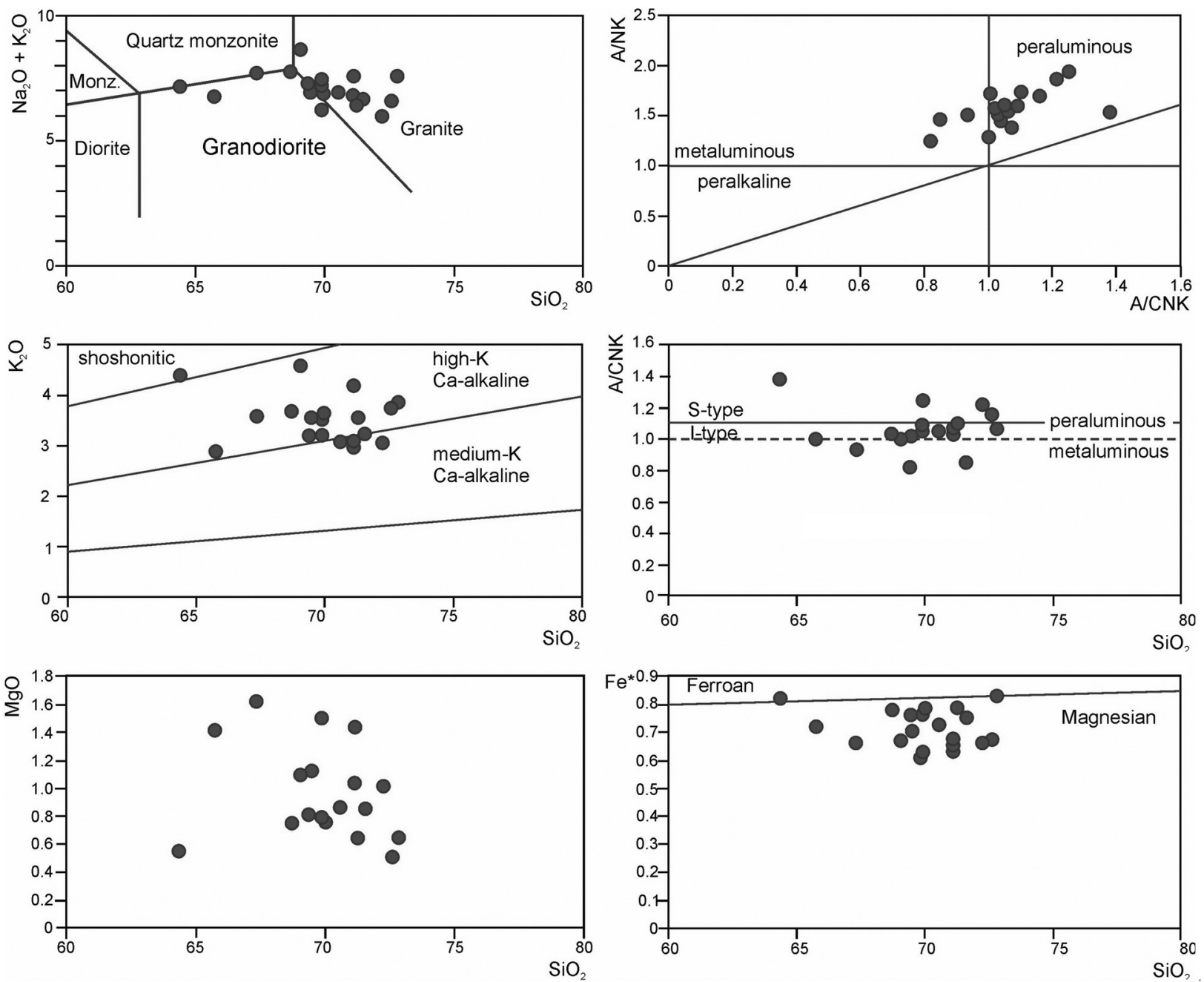

Fig. 12. Chemical diagrams for the Spanchevo granites (after data of Slavov et al., 1974; Boyadjiev, 1989; Machev, 1993). 
ment fault (see Sarov et al., 2010), which represents a complex tectonic zone of multiphase deformations.

\section{Bezbog pluton}

The intrusive relations between the porphyric granites and the medium-grained Pirin-type granites along the road from Pirin Village to the mountain hut Pirin (Velebit) were first described by Boyadjiev (1959). During the geological mapping in scale 1:25 000 (Zagorčev et al., 1974, Slavov et al., 1976), these relations were confirmed on a larger scale, and it has been suggested that the remnants of porphyric and coarse-grained granites at the periphery of the eastern (Hleven) dome of the Central Pirin plutons belonged to an older Bezbog (Konarevo) pluton exposed primarily on a surface of ca $160 \mathrm{~km}^{2}$ (see also Marinova and Zagorčev, 1990, 1993; Zagorčev, 1994a). These granitoid relics are now scattered in several areas: along the northern parts of Pirin (Demyanitsa area) where they are in contact with the Lukovitsa and Dobrostan formations; in the central parts of Pirin, at the peaks Kuklite, Stefanov Vrah and Arabski Grob where they are in contact with xenoliths of the Vacha Varied Formation preserved as parts of a former septum; along the eastern slope of Pirin where they are strongly deformed and have been partially referred to another relic Zmeyski pluton (Slavov et al., 1976). Dimitrova and Sarafova (1968), Dimitrova (1971), Machev (1993), Milovanov et al. (2009), and Klimov et al. (2009) are on the opinion that the Bezbog and Demyanitsa granites are different facies of the same granite and they belong to the Central Pirin pluton. Machev (1993) distinguished a small Demyanitsa pluton in the northernmost parts of the Pirin Mountain west of the Demyanitsa River.

The structural features and geological field relations are clearly in favour of the opinion on the independent character of the Bezbog pluton in respect to the Central Pirin pluton (Zagorčev et al., 1974; Slavov et al., 1976). This conclusion is based on its structural "autonomy": sharp intrusive contact of the younger (Central Pirin) pluton and disconformity of both the internal and external (contacts) structure of the latter (Fig. 9e). However, this conclusion does not contain any inference about the time gap between the solidification of the Bezbog pluton and the intrusion time of the Central Pirin granitoids or about the homogeneity or inhomogeneity of the Bezbog/Demyanitsa granites themselves. Within the following lines, we will give some petrologic and geochemical information about the two major varieties (porphyric Bezbog and coarsegrained Demyanitsa granites), following the existing evidence (after Slavov et al., 1974; Machev, 1993; Milovanov et al., 2009).

According to all previous authors, the porphyric Bezbog granodiorite to granite and the coarse-grained Demyanitsa granite have a transitional boundary. The Bezbog granodiorite is rich in xenoliths from the host rocks and contains porphyric $\mathrm{K}$-feldspar in proportions reaching up to $50 \%$ of the rock volume. The main minerals are plagioclase (Bezbog - 35-45\%; Demyanitsa - 50-60\%), K-feldspar (Bezbog - 18-27\%, microperthitic orthoclase; Demyanitsa - ca 20\%, microperthitic microcline), quartz (Bezbog - 25-30\%, Demyanitsa - ca 20\%) and minor amount (4-7\%) of biotite. Zoned plagioclase has a core of $\mathrm{An}_{30-35}$ and mantle of $\mathrm{An}_{15-24}$ (Bezbog) and core of $\mathrm{An}_{30-35}$ and mantle of $\mathrm{An}_{20-28}$ (Demyanitsa); a second plagioclase generation of $\mathrm{An}_{15}$ is reported for the Demyanitsa granite. The other rock-forming minerals are hornblende, zircon, allanite, monazite, apatite, titanite, and ore.

The Bezbog granitoids are granites in transition to granodiorites and quartz-monzonites, predominantly high-K calcalkaline, with some samples deviating into the shoshonitic field (Fig. 13). They fall in the transition area of peraluminous and metaluminous rocks, and entirely within the field of I-type granitoids according to the $\mathrm{A} / \mathrm{CNK}$ vs $\mathrm{SiO}_{2}$ diagram.

\section{Alpine plutons of Pirin type (Pirin granitoid association)}

Having been considered for a long time as belonging to the group of the Hercynian South Bulgarian granites (Dimitrov, 1959), the "plutons of Pirin type" have been separated (Boyadjiev, 1959) as an independent group of Alpine granitoids, and later studied and discussed as such by all following authors (Boyadjiev and Lilov, 1972, 1976; Zagorčev and Moorbath, 1983; Zagorčev et al., 1974, 1987, 1989; Slavov et al., 1976; Amov et al., 1982; Boyadjiev, 1989, 1991; Kozhoukharov and Marinova, 1991; Katzkov and Marinova, 1992; Machev, 1993; Zagorčev, 1994a, 1995; Machev and Rashkova, 2000; Veit et al., 2003; Klimov et al., 2009; Milovanov et al., 2009; Sarov et al., 2010, 2011; Filipov and Marchev, 2011, 2012; Georgiev et al., 2011, 2012; Filipov et al., 2012, 2014; Filipov, 2014). These plutons include on Bulgarian territory the North Pirin (Dautov, Kresna), Breznitsa, Central Pirin, Teshovo (South Pirin), Goleshevo, and Lehovo magmatic bodies, and a number of small bodies and dykes, some of them playing the role of stitching bodies along the NNW prolongation of the Mesta fault zone in the Rila Mountain. The continuation on the territory of Northern Greece includes the Vrondou, Pangaion, Symvolon, and Xanthi plutons (Dimitrov, 1957; Meyer, 1968; Del Moro et al., 1988, 1990; Kolokotroni and Dixon, 1991; Koukouvelas and PePiper, 1991; Eleftheriadis, 1995; Eleftheriadis et al., 2001; Soldatos et al., 2001, 2008; Eleftheriadis and Koroneos, 2003; Perugini et al., 2004; Christofides et al., 2014; and references therein). The Palaeogene age has first been proven for the Xanthi pluton (Dimitrov, 1957) by its intrusive relations (with development of contact hornfelses) with Palaeogene sediments, and further ascertained for other bodies with isotopic studies by Amov et al. (1982), Zagorčev et al. (1987) and many other authors. N. Zidarov (pers. comm., 1969) 

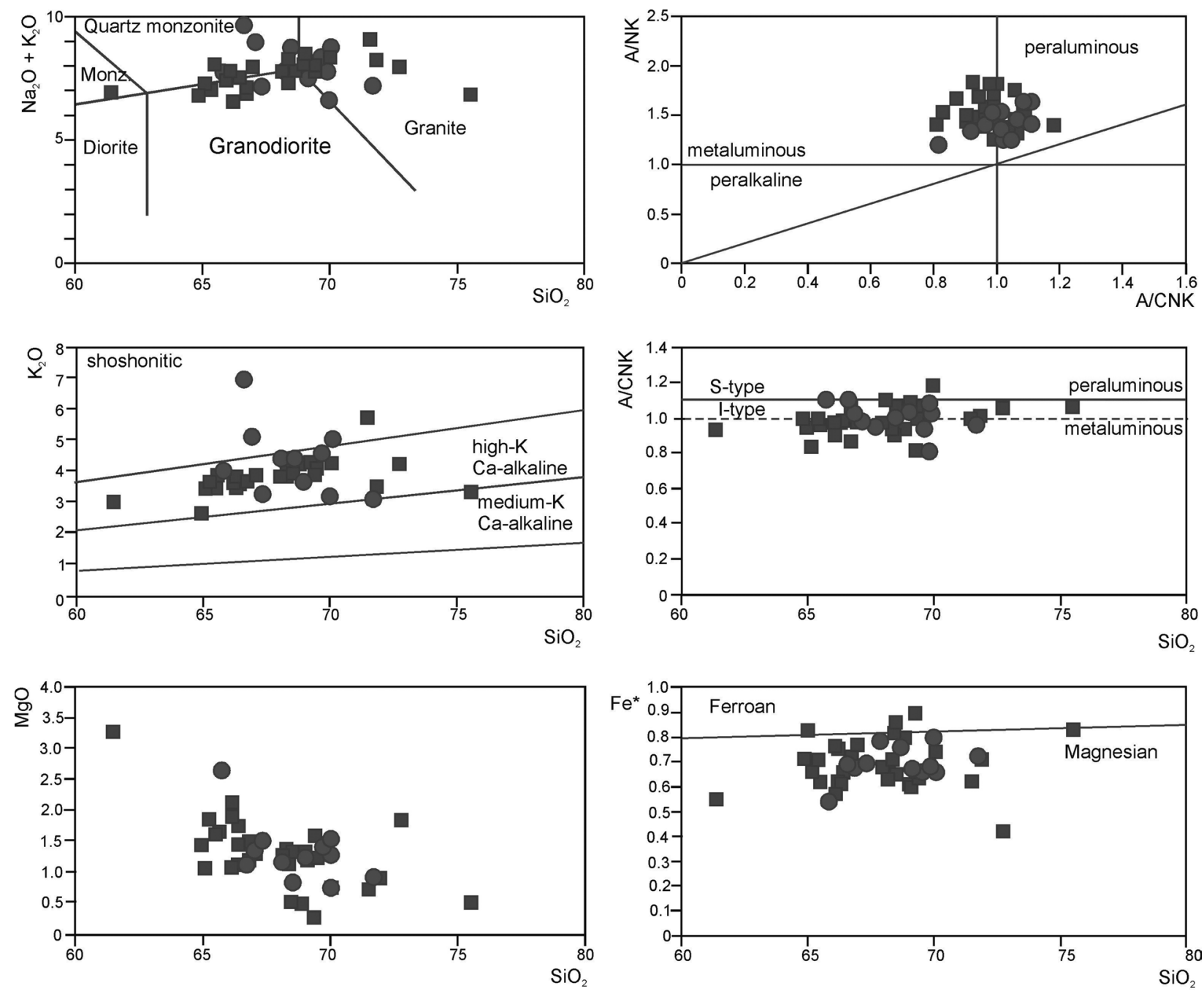

Pirin-type granites (Dautov, Central Pirin, Teshevo)

Bezbog granite

Fig. 13. Chemical diagrams for the Bezbog granite and for the granites of Pirin type (North Pirin, Central Pirin, South Pirin, Lehovo, and Goleshevo plutonic bodies); after data of Slavov et al. (1974), Boyadjiev (1989), Machev and Rashkova (2000).

and Slavov et al. (1976) first pointed at the petrological and geochemical similarities and assumed relationships between the Pirin-type granitoids and the Mesta (and Padesh) volcanic complexes, uniting them into a volcano-plutonic association confirmed also recently (Filipov and Marchev, 2011; Georgiev et al., 2012; Filipov et al., 2012, 2014; Filipov, 2014) with extensive geochemical studies. This association has been interpreted as a part of the Macedonian-Rhodope magmatotectonic province (Harkovska et al., 1989). Obviously, an exhaustive characterisation of the Mesta-Pirin volcano-plutonic association and of the whole Macedonian-Rhodope province is exceeding by far the limits of the present paper and is outside our aims. We shall stress only on some of the typical features of the Pirin granitoids that are in direct relations with the tectonometamorphic and igneous evolution of the Pirin-Pangaion Unit.
The Pirin granitoid association consists of intrusive bodies of different size: from batholithic dimensions to small bodies and dykes. The three (North Pirin, Central Pirin, and South Pirin) big plutons are of batholithic dimensions and have domal shapes elongated in NNE-SSW direction. The Central Pirin pluton consists of two (Spano Pole and Hleven) domes, the eastern one intruding and deforming the Bezbog pluton. The petrological composition of the association on Bulgarian territory is restricted to biotite and hornblendebiotite granites with transitions towards granodiorites, granosyenites, and quartz-monzonites. In the southernmost part of the association outcrops, the Xanthi pluton is built up of basic (gabbro, gabbrodiorite) and monzonitic to quartz-monzonitic phases. Skarns and hornfelses are typical for the contact zones, mostly of the Xanthi and South Pirin plutons. Thin aplite dykes are typical and, to a lesser extent, pegmatites. Cavi- 
ties in the latter often contain quartz crystals. Some of the rock varieties (Breznitsa body, the periphery of the North Pirin and some parts of the Central Pirin and South Pirin bodies, some of the dykes) exhibit indications (e.g., polyphyric structure) for a very shallow crustal solidification of granitoid and monzonitoid magmas. The monzonitic structure, the presence of at least two generations of plagioclase, and combination (synneusis) twins indicate a prolonged maturation of the magmas. The geochemical characteristics (see Zagorchev and Moorbath, 1983; Zagorchev et al., 1987; Del Moro et al., 1988; Christofides et al., 1998, 2014; Machev and Rashkova, 2000; Eleftheriades and Koroneos, 2003; Perugini et al., 2004; Filipov, 2014) indicate mixing and mingling of two types of magmas, of mantle and of crustal origin, and considerable crustal contamination (high initial ${ }^{87} \mathrm{Sr} /{ }^{86} \mathrm{Sr}$ values).

\section{ISOTOPIC GEOCHRONOLOGY IN THE PIRIN MOUNTAIN (RESULTS AND INTERPRETATIONS)}

\section{Rhodopian supercomplex}

The isotopic geochronological studies within the Pirin subunit are scarce and unevenly distributed throughout the areas built up of metamorphic rocks, and within the metamorphic lithostratigraphic (or lithotectonic) units. The results are shown in Table 2. The only results published concern the Bachkovo complex (Kriva-reka orthogneisses) near Yane Sandanski Memorial (Machev and Ovcharova, 2008) and the Bogutevo Formation at Obidim (Peytcheva et al., 2009). Some of our data are subject of two preliminary publications (Zagorchev et al., 2012, 2016). In the present paper, we supply all data obtained, together with interpretations and implications for the overall tectonometamorphic history of Pirin.

The Rupchos complex in the northernmost (Krupnik) metamorphic area was sampled with four samples. The sites of three of them $(298,299 \mathrm{~b}, 300)$ are situated in the westernmost part of the section along the road Sushitsa-Polena, and sample 557 comes from the septum at the northern entrance of the Kresna Gorge.

The amphibolite (sample 298) is highly inhomogeneous, with separate layers that are almost entirely built up of amphibole, with occasional large- to medium-sized garnet crystals. Most of the layers are affected by migmatisation (Fig. 5): usually stromatic, with variable amount of leucosome (from incipient to prevailing). The more massive layers are often boudinaged, whereas the migmatitic layers are recrystallised, with abundant biotite, and folded in isoclinal folds. After the isoclinal folding of the migmatised amphibolites and biotite-hornblende migmatites together with the granitoid and aplitoid parallel-layer quartzofeldspathic gneisses (supposedly of anatectic origin), the rocks have been affected by a new anatexis with extraction of quartzo-feldspathic material obliquely or cross-cutting the former structure. The sample was taken from the more mafic and homogeneous layers. However, the zircons show a considerable scattering: from Cadomian to Hercynian values (Table 2), and a concordant date of ca 398.6 \pm 6.4 Ma with doubtful geological meaning. The data is inconclusive. A tentative Discordia line has an upper intercept with the Concordia at about $528 \mathrm{Ma}$ and a lower intercept of ca $223 \mathrm{Ma}$ (Fig. 14). The first date is regarded as being close to the amphibolite-facies metamorphism and migmatisation, whereas the lower intercept roughly corresponds to the age $(237.7 \pm 1.9 \mathrm{Ma})$ of the nearby Krupnik granite (see next paragraph). The data about the individual zircon ages range between $491 \mathrm{Ma}$ and $306 \mathrm{Ma}$, and are consistent with the hypothesis of a Cadomian metamorphism superposed by later (Hercynian) metamorphism.

Sample 299b comes from a xenolith of amphibolite composition (similar to sample 298) within the apophysis of the Krupnik granite pluton. The outcrop is situated at several tens of metres east of site 298. Xenoliths within the Krupnik granite in this apophysis exhibit different degrees of resorption within the granite: from xenoliths with angular sharp contacts and no visible resorption to full resorption with preservation of unclear contours and ghostly internal structure. The xenolith sampled (Fig. $5 f$ ) belongs to the first group: a migmatised amphibolite with aplitoid quartz-feldspar metatect, all contacts of palaeosome and neosome (leucosome) being sharply cut by the granite contact. The material analysed comes from the quartz-feldspar leucosome (metatect). The age determined (Fig. 14) is $517.5 \pm 1.4 \mathrm{Ma}$, and all zircons dated fall within the range between $530 \mathrm{Ma}$ and $500 \mathrm{Ma}$, thus being interpreted as a result of a Cadomian migmatisation of the Rupchos complex (Chepelare Formation?).

The last sample along the Sushitsa-Polena road cuttings comes from an outcrop situated at a few tens of metres east of the previous exposure, where amphibolites, hornblende-biotite, and biotite gneisses are interlayered with biotite quartzo-feldspathic gneisses. The sample was taken from the quartzo-feldspathic gneisses. The age determined $(240.45 \pm 0.45 \mathrm{Ma})$ is almost identical to the age of the Krupnik granite, and the range of the dates of the zircon grains measured is between 279.4 Ma (Permian) and 159.3 Ma (Jurassic). These results may be interpreted as indication for local metatexis event synchronous to the intrusion of the Krupnik granite and, also locally, for post-granitic deformations leading to the metamorphism of the Permo-Triassic aplitic metatect into aplitoid (quartzofeldspathic) gneiss.

The metamorphic septum (Zagorčev, 1994a; Zagorchev, 1995; Zagorchev et al., 2012) that had been preserved as a thin (tens to few hundred metres) rim between the Kresna and the Krupnik plutons was considered as an important marker for the tectono- 
Table 2

Isotopic age data for the Pirin subunit

\begin{tabular}{|c|c|c|c|c|}
\hline $\begin{array}{l}\text { Sample } \\
\text { No. }\end{array}$ & Rock type & $\begin{array}{l}\text { Coordinates and altitude, } m \text { (this study). } \\
\text { Location/locality (previous studies) }\end{array}$ & Concordia age, $\mathrm{Ma}$ & Age range of zircon grains \\
\hline 298 & amphibolite & $\mathrm{N} 41^{\circ} 49.154 ; \mathrm{E} 23^{\circ} 04.674 ;$ alt. $742 \mathrm{~m}$ & $398.6 \pm 6.4$ & $491.4-306.3 \mathrm{Ma}$ \\
\hline 298 & amphibolite & \multicolumn{3}{|c|}{ (Discordia upper intercept//lower intercept) 528+42/-36//223+52/-70 } \\
\hline $299 \mathrm{a}$ & Krupnik granite & N41ํ⒐614; E2305.654; alt. 587 m & $242.4 \pm 1.3$ & $530.5-193.6-(33.8)$ \\
\hline $299 b$ & amphibolitic xenolith & $\mathrm{N} 41^{\circ} 49.614 ; \mathrm{E} 23^{\circ} 05.654 ;$ alt. $587 \mathrm{~m}$ & $517.5 \pm 1.4$ & $530.3-500.6 \mathrm{Ma}$ \\
\hline 300 & Q-fs gneiss & $\mathrm{N} 41^{\circ} 49.614 ; \mathrm{E} 23^{\circ} 05.654 ;$ alt. $587 \mathrm{~m}$ & $240.45 \pm 0.45$ & $279.4-159.3 \mathrm{Ma}$ \\
\hline 557 & anatectite in septum & $\mathrm{N} 41^{\circ} 50.188 ; \mathrm{E} 23^{\circ} 08.559 ;$ alt. $240 \mathrm{~m}$ & $305.5 \pm 2.8$ & $339.1-37.1 \mathrm{Ma}$ \\
\hline 309 & Bachkovo gneiss & $\mathrm{N} 41^{\circ} 31.860 ;$ E2336.169; alt.1175 m & $289.6 \pm 0.94$ & $579.4-197.6 \mathrm{Ma}$ \\
\hline 310 & Lukovitsa gneiss & $\mathrm{N} 41^{\circ} 31.937 \mathrm{E} 23^{\circ} 36.519$ alt. $1270 \mathrm{~m}$ & $300.8 \pm 1.8$ & $318.4-216.6 \mathrm{Ma}$ \\
\hline MO & Bachkovo gneiss & Yane Sandanski monument & $300.1 \pm 2.3$ & \\
\hline $\mathrm{Pe}$ & Obidim metagabbro & Mesta; $N^{\circ} 41^{\circ} 46^{\prime} 53^{\prime \prime} ;$ E 2339’34” & $454.1 \pm 8.3$ & $430-460 \mathrm{Ma}$ \\
\hline $\mathrm{Pe}$ & Obidim metadiorite & Between Obidim and Mesta & $446 \pm 7$ & \\
\hline $\mathrm{Pe}$ & Obidim metagranite & Mesta Village & $456.1 \pm 1.8$ & \\
\hline $\mathrm{Pe}$ & leucosome vein & SE of Obidim Village & $321 \pm 19$ & \\
\hline MF, Fi & Kremen gabbro? (Fi) & Diorite sample PF29 (MF) & $85.27 \pm 0.92$ & $445.3 \mathrm{Ma}$ \\
\hline $\mathrm{MF}, \mathrm{Fi}$ & Kremen diorite (Fi) & Dioritic porphyrite PF27 (MF) & $71.2 \pm 0.58$ & $216-103 \mathrm{Ma}$ \\
\hline Sp1 & Spanchevo granite & $\mathrm{N} 41^{\circ} 30.687 ; \mathrm{E}^{\circ} 3^{\circ} 32.030 ;$ alt. $694 \mathrm{~m}$ & $55.04 \pm 0.24$ & $60.1-54.2 \mathrm{Ma}$ \\
\hline Sp2 & Spanchevo granite & $\mathrm{N} 41^{\circ} 30.687 ; \mathrm{E}^{\circ} 3^{\circ} 32.030 ;$ alt. $694 \mathrm{~m}$ & $57.23 \pm 0.42$ & $59.6-54.9 \mathrm{Ma}$ \\
\hline $\mathrm{K} 1$ & Spanchevo granite & & $58.4 \pm 1.1$ & $63-5 \mathrm{Ma}$ \\
\hline$J-A$ & Spanchevo granite & & $56.0 \pm 0.5$ & $147-140 \mathrm{Ma} ; 59-54 \mathrm{Ma}$ \\
\hline $\mathrm{Fi}$ & Demyanitsa granite & Zmeyski granitoids & $\begin{array}{l}57.08 \pm 0.75 \\
56.72 \pm 0.3\end{array}$ & $140.2-54.5 \mathrm{Ma}$ \\
\hline Mi1 & Bezbog granite & & $34.48 \pm 0.48$ & zircon \\
\hline Mi2 & Bezbog granite & & $34.7 \pm 2.7$ & monazite \\
\hline Fi, FM & Bezbog granite & & $33.14 \pm 0.21$ & \\
\hline $\mathrm{Fi}, \mathrm{FM}$ & Coarse-grained granite & & $34.06 \pm 0.11$ & $36.8-35.5 \mathrm{Ma}-34.8-33.4 \mathrm{Ma}$ \\
\hline ZM & Bezbog/Demyanitsa & & $88 \pm 9$ & $\mathrm{Rb}-\mathrm{Sr}$ \\
\hline SG & Krupnik?? & Granite attributed to Krupnik pluton & $34.07 \pm 0.19$ & \\
\hline ZM & Dautov (Kresna) & & $92 \pm 22$ & $\mathrm{Rb}-\mathrm{Sr}$ \\
\hline SG & Dautov (Kresna) & $\begin{array}{l}\text { zircons } \\
\text { monazites }\end{array}$ & $\begin{array}{l}35.06 \pm 0.54 \\
32.07 \pm 0.17\end{array}$ & $1200-110 \mathrm{Ma}$ \\
\hline SG & Breznitsa & & $33.98 \pm 1.9$ & \\
\hline Mi3 & Kresna? granite & Kresna gorge & $32.99 \pm 0.39$ & \\
\hline 301 & Kresna granite & N41 ${ }^{\circ} 47.477$; E2309.663; alt. 235 m & $31.71 \pm 0.15$ & $566.1-27.7 \mathrm{Ma}$ \\
\hline FM & Central Pirin granite & & $32.61 \pm 0.34$ & \\
\hline $\mathrm{ZM}$ & Central Pirin granite & & $34 \pm 2-37 \pm 2$ & $\mathrm{Rb}-\mathrm{Sr}$ \\
\hline Мa & Teshovo granite & & $32.6 \pm 0.61$ & $\mathrm{Rb}-\mathrm{Sr}$ \\
\hline $\mathrm{J}-\mathrm{A}$ & Teshovo granite & & $32.2 \pm 0.2$ & 34-30 Ma \\
\hline
\end{tabular}

References: MO - Machev and Ovcharova (2008); Pe - Peytcheva et al. (2009); Kl - Klimov et al. (2009); J-A - Jan-Awe et al. (2010); Mi1, Mi2, Mi3 - Milovanov et al. (2009); FM - Filipov and Marchev (2010, 2012); Fi - Filipov (2014); ZM - Zagorchev and Moorbath (1987); Ma - Machev et al. (2000); SG - Georgiev et al. (2012); MF - Marchev and Filipov (2012)

metamorphic evolution of Northern Pirin. The rocks of the Rupchos complex have been transformed into nebulites with ghost structures of former foliation and metamorphic banding; granitised former boudins (initially built up of amphibolites) have been transformed into hornblende-biotite gneisses. The sample (No 12557) was taken from the homogenised nebulites in the road cuttings of road E-79. The U-Pb zircon data in- dicates a concordant zircon age of ca $305.5 \pm 2.8 \mathrm{Ma}$. The individual data points range between ca $339 \mathrm{Ma}$ and $238 \mathrm{Ma}$ (age of the Krupnik pluton), with a few Mesozoic ages and three data points between $49.5 \mathrm{Ma}$ and $37 \mathrm{Ma}$. A Discordia of all zircon figurative points has an upper intercept with the Concordia at 333 $\pm 22 \mathrm{Ma}$ (Fig. 15). These data define the nebulitisation and diatexis as Hercynian (ca $330 \mathrm{Ma}$ to $300 \mathrm{Ma}$ ) with 

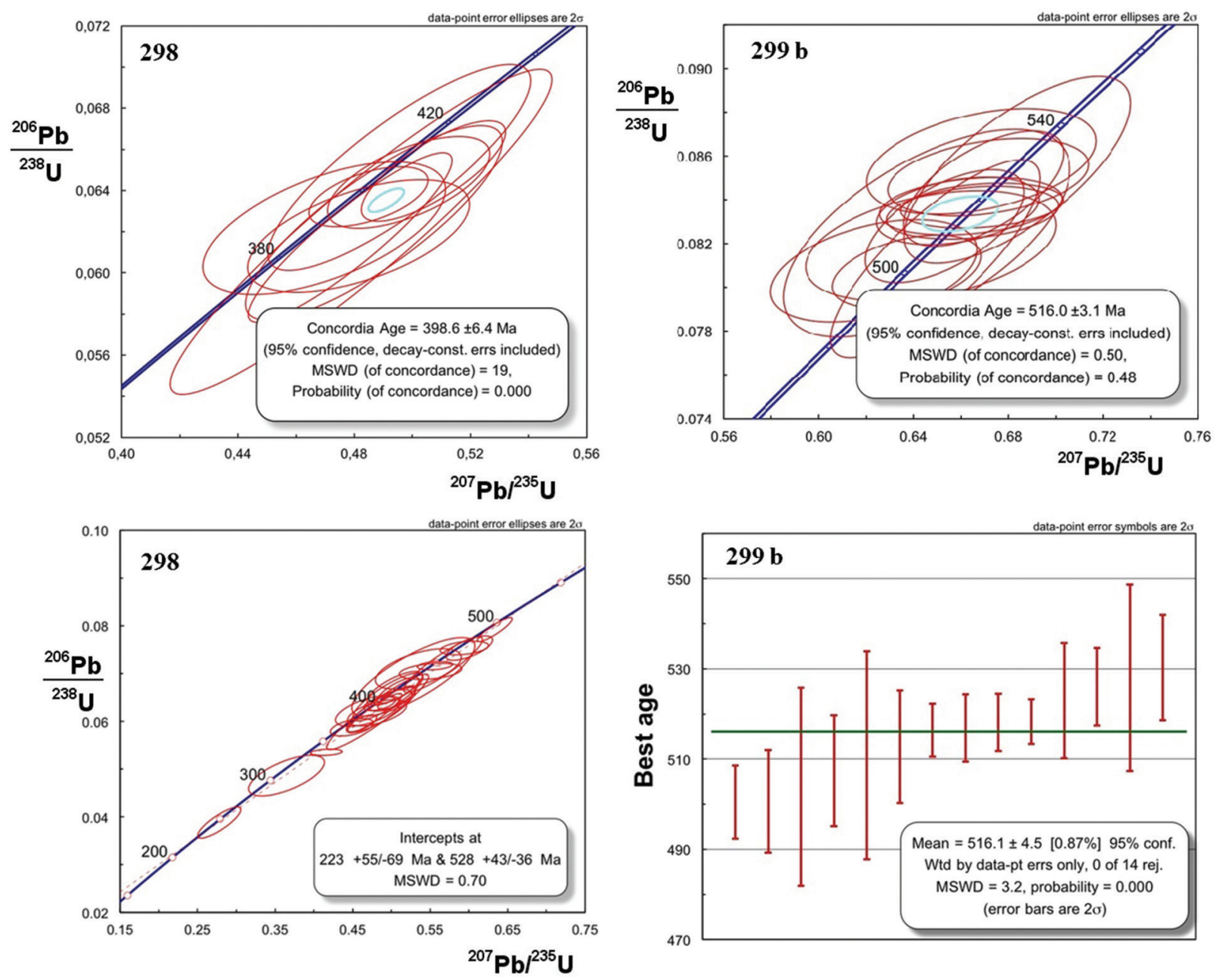

Fig. 14. Isotopic age diagrams for samples 298 (amphibolite) and 299b (amphibolite from xenolith in the Krupnik granite), Krupnik area.

a slight overprint connected to the nearby large North Pirin (Dautov, Kresna) granite pluton of early Oligocene age.

Hercynian events are recorded also as the principal events in the tectonometamorphic evolution of the southern Pirin area. There, the overturned Rhodopian section contains the undifferentiated Boykovo and Bachkovo formations ("Kriva reka orthogneisses" of Machev and Ovcharova, 2008, and Klimov et al., 2010) situated in the geometrical profile over the Lukovitsa Varied Formation, and the Dobrostan Marble Formation at the geometric base. The only U-Pb isotopic determination on zircons up to now (Machev and Ovcharova, 2008) from the "Kriva reka orthogneisses" yielded ca $300 \mathrm{Ma}$. We sampled the same quartzofeldspathic gneisses near the small memorial to Yane Sandanski (sample 309), as well as a thin quartzofeldspathic layer within the garnet-biotite schists of the Lukovitsa Formation (sample 310).
The biotite quartzo-feldspathic gneisses at the Yane Sandanski Memorial (sample 309; across the road from the parking lot at the fountain) yielded a concordant age of $289.6 \pm 0.94 \mathrm{Ma}$ (Fig. 16). Although not absolutely identical with the age obtained $(300.1 \pm 2.3 \mathrm{Ma})$ by Machev and Ovcharova (2008), the data are similar and fall within the same range of Hercynian ages (ca 290-320 Ma) obtained also in the Central and Eastern Rhodopes. A great scatter of the individual zircon ages (from 579.4 Ma to 197.6 Ma) is observed (Table 2). This scatter is explained both as presence of inherited zircons coming from the Cadomian protolith and (for the youngest ages) as formation of late zircons, or resetting during later (Mesozoic) events.

A thin 3-5 cm layer of biotite quartzo-feldspathic gneiss (metagranite? layer-parallel vein) was sampled (sample 310) within the schists of the Lukovitsa Formation near the boundary with the next Dobrostan Marble Formation (Fig. 9b). At a few metres from 

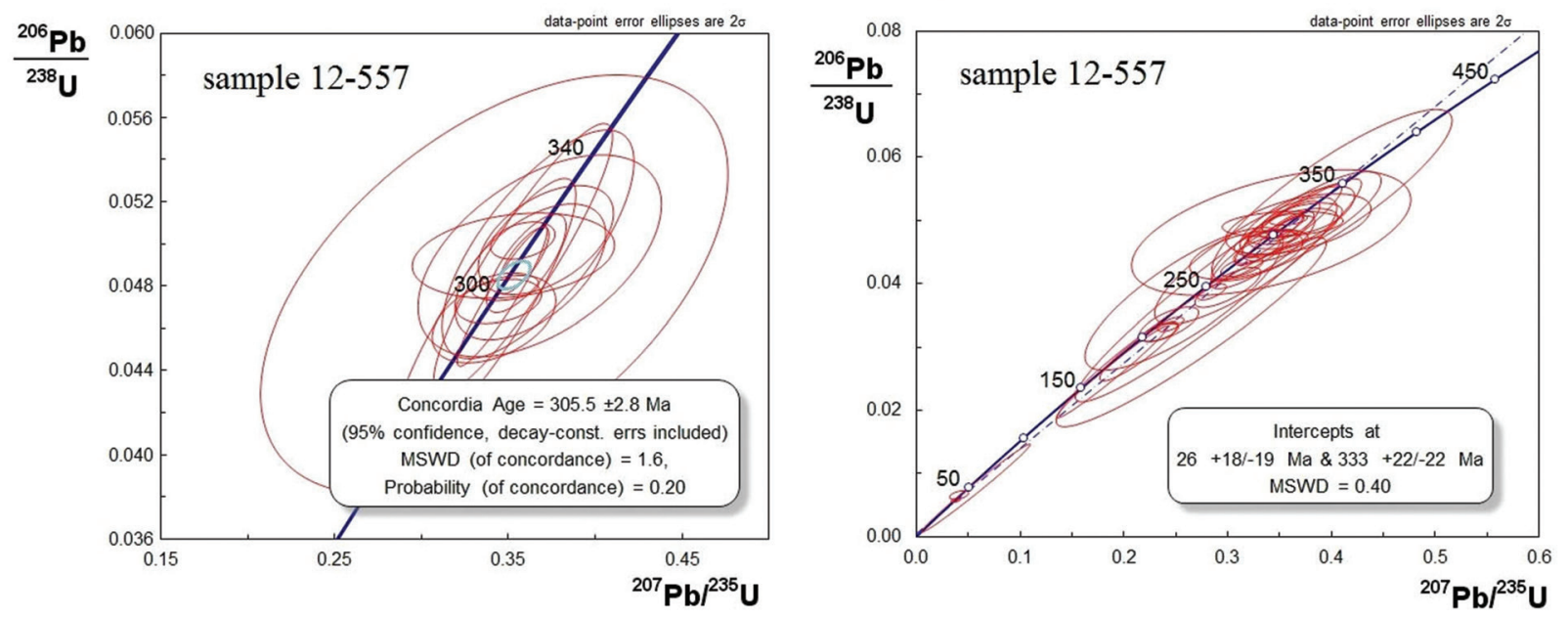

Fig. 15. Isotopic age diagrams for sample 12-557 (granitised gneiss from septum), Krupnik area.

the same place H.-J. Massonne sampled the host andalusite-garnet-biotite schists (metapelites) briefly described (after Massonne, 2016) above. Our sample yielded a well-defined concordant $\mathrm{U}-\mathrm{Pb}$ zircon age of $300.8 \pm 1.8 \mathrm{Ma}$, with a scatter limited between $318.4 \mathrm{Ma}$ and 216.6 Ma (Table 2). The concordant age is identical with the age of the "Kriva-reka orthogneisses" of Machev and Ovcharova (2008), and similar to the concordant age of our sample 309 from the Bachkovo gneisses, both at the Yane Sandanski Memorial. This data indicates that both the Bachkovo ("Kriva reka") gneisses and the Lukovitsa schists (metapelites) have been subjected to Hercynian metamorphism and anatexis, with different degrees of preservation of older (protolithic and older metamorphic) zircons, and influence by younger (Mesozoic and Palaeogene) metamorphic and igneous (granites) events.

The metamorphic rocks of the Rupchos complex (Bogutevo Formation) from the Obidim area were dated by Peytcheva et al. (2009) by ID-TIMS and LA-ICP-MS measurements on zircons. A Discordia with upper intercept of $454.1 \pm 8.1 \mathrm{Ma}$ and a poorly defined Hercynian lower intercept is obtained by IDTIMS for a metagabbro; the LA-ICP-MS data are younger, but a Discordia upper intercept points at about $440 \mathrm{Ma}$. A metadiorite sample yielded by LA-ICP-MS a Discordia with an upper intercept of $446 \pm 7$ Ma. A coarse-grained "metagranite" was dated by Discordia (TIMS) upper intercept at $456.1 \pm 1.8 \mathrm{Ma}$, and mylonitised gneiss dated at $452 \pm 14 \mathrm{Ma}$ (LA-dating). All these data have been interpreted as Ordovician protolith ages (Peytcheva et al., 2009). U-Pb dating of zircon rims from leucosome yielded, by LA-ICP-MS, ages of $321 \pm 19 \mathrm{Ma}$, interpreted as Hercynian highgrade overprint. Monazites have also been studied. Their ${ }^{\circ 206} \mathrm{~Pb} /{ }^{238} \mathrm{U}$ ages range between $220 \mathrm{Ma}$ and
$260 \mathrm{Ma}$ ", and "it is likely that [these] ages are geologically meaningless. We suppose that the monazites lie on a [D] iscordia with Variscan upper intercept and an Alpine lower intercept" (Peytcheva et al., 2009, p. 18). The dominant Ordovician to Silurian dates are similar to the datings of granitoids and the major metamorphic events within the Vertiscos and Ograzhden units reported in the geological literature during the last decade.

\section{Krupnik granitoids}

The Krupnik granitoids have been traditionally referred to the South Bulgarian granitoids of Hercynian age. However, the first U-Pb dates obtained on zircons and reported only as a measurement without detailed evidence (Milovanov et al., 2009, 2010) corresponded to the early Oligocene (32.99 $\pm 0.39 \mathrm{Ma})$, and a similar age (34.07 $\pm 0.19 \mathrm{Ma})$ was reported by Georgiev et al. (2012). Neither the sampling localities nor the descriptions of the samples and their relations with the other rock varieties have been reported. Detailed laboratory data have not been published, either. It may be inferred from the descriptions in the cited sources that the sample sites may have been near the eastern boundary of the pluton not far from the Palaeogene Dautov (Kresna) pluton, where the Krupnik granitoids contained numerous dykes of the latter.

Our sampling (sample 299a) was focused on a small body, apophysis of the Krupnik granite near the northwestern contact of the main body along the road from Sushitsa to Polena. The Krupnik granitoids at the locality are coarse-grained and porphyric granites that contain numerous angular xenoliths of the host rocks (Fig. 5f) without signs of resorption and of visible contamination of the granite. The quartzo- 

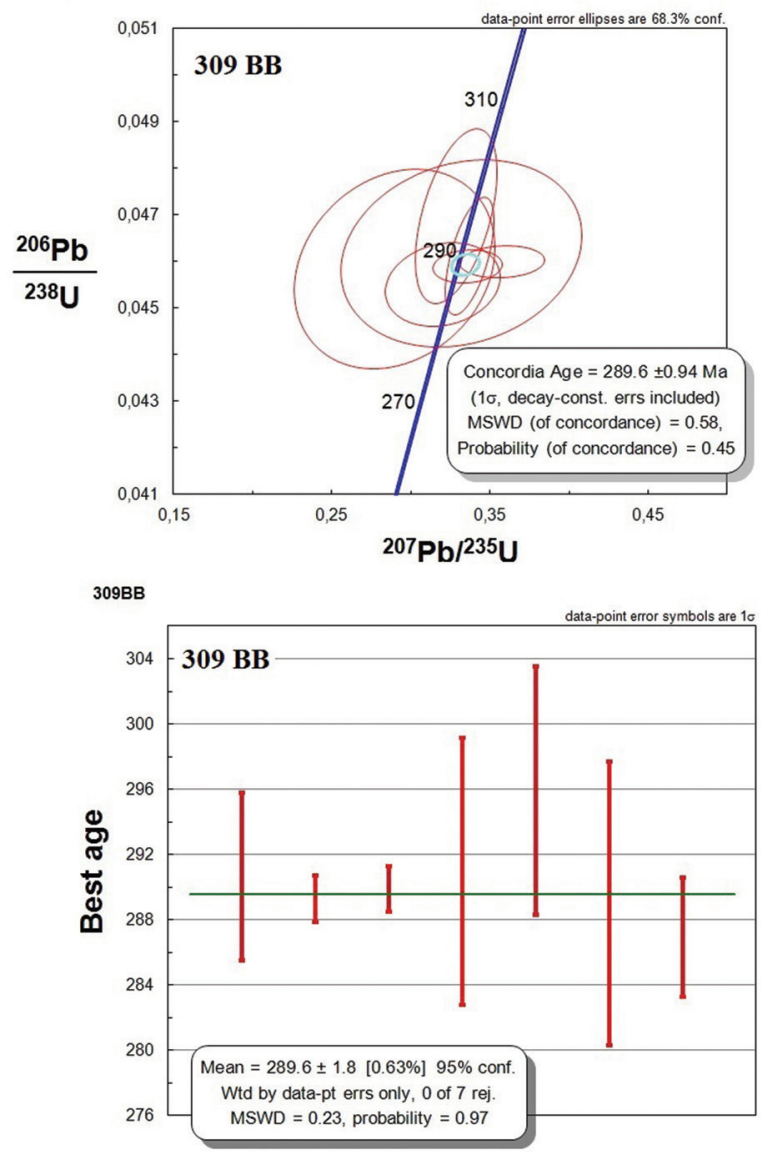

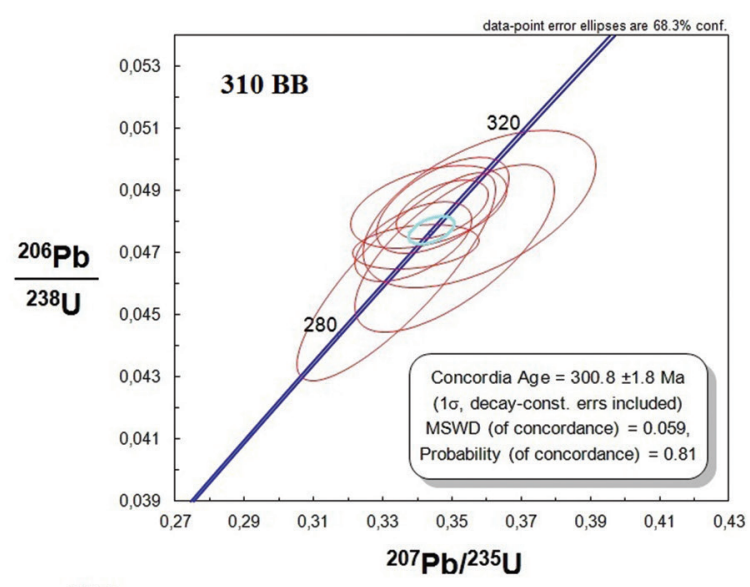

310BL

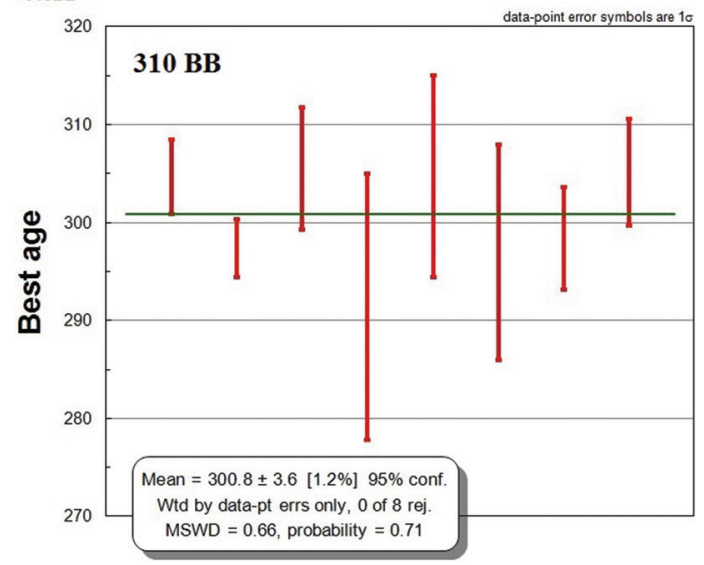

Fig. 16. Isotopic age diagrams for samples 309 (quartzo-feldspathic gneiss, Bachkovo Fm.) and 310 (quartzo-feldspathic material in metapelite), southern Pirin area.

feldspathic material from a xenolith yielded a Cadomian age (Table 2).

The age of the granite was determined (Zagorchev et al., 2012) to $237.7 \pm 1.9 \mathrm{Ma}$ (Concordia age), now recalculated to $242.4 \pm 1.3 \mathrm{Ma}$. The intrusion time is interpreted as latest Palaeozoic to earliest Triassic (Fig. 17). The data show a large dispersion between $530 \mathrm{Ma}$ and $28 \mathrm{Ma}$ on the Concordia and, as a consequence, it is difficult to draw a unique solution. The older (Palaeozoic) zircon grains and grain cores are considered to be inherited grains coming from xenoliths in different degrees of resorption. The dating of the older zircons and zircon cores covers a vast interval from about $530 \mathrm{Ma}$ to $193.6 \mathrm{Ma}$, the most coherent group being between $258 \mathrm{Ma}$ and $228 \mathrm{Ma}$. A few (four) grains are grouped around $33.8 \mathrm{Ma}$. The dating of this minor group roughly corresponds to the time of the Oligocene North Pirin (Dautov, Kresna) pluton and of the young subvolcanic dykes that intersect the Krupnik pluton and its host metamorphics. We also sampled a foliation-parallel layer of quartzo-feldspathic ("leptitoid") gneiss within the latter. The quartz-feldspar separation from this aplitoid material (sample 300) yielded practically the same age $(240.45 \pm 0.43 \mathrm{Ma})$ as the Krupnik porphyroid granite. The range of the older zircons is between 279.4 Ma and 159.3 Ma (Table 2). This indicates that this "leptitoid gneiss" was in fact either a gneissified layer-parallel aplitoid dyke related to the Krupnik granite intrusion (Zagorchev et al., 2012) or a metatect from the time of this intrusion.

\section{Kremen Late Cretaceous diorites}

Marchev and Filipov (2012) and Filipov (2014) reported within the Obidim unit at the village of Kremen the presence of basic rocks of Late Cretaceous age. An altered hornblende diorite (Marchev and Filipov, 2012) is "composed of hornblende, plagioclase, biotite, magnetite and accessory apatite, zircon and allanite", and an age of $85.27 \pm 0.92 \mathrm{Ma}$ has been determined by LA-ICPMS measurements of nine spots within short prismatic zircons. Filipov (2014) reported hornblende gabbro (or gabbrodiorite) with the same composition and age; 27 zircon grains from two sam- 

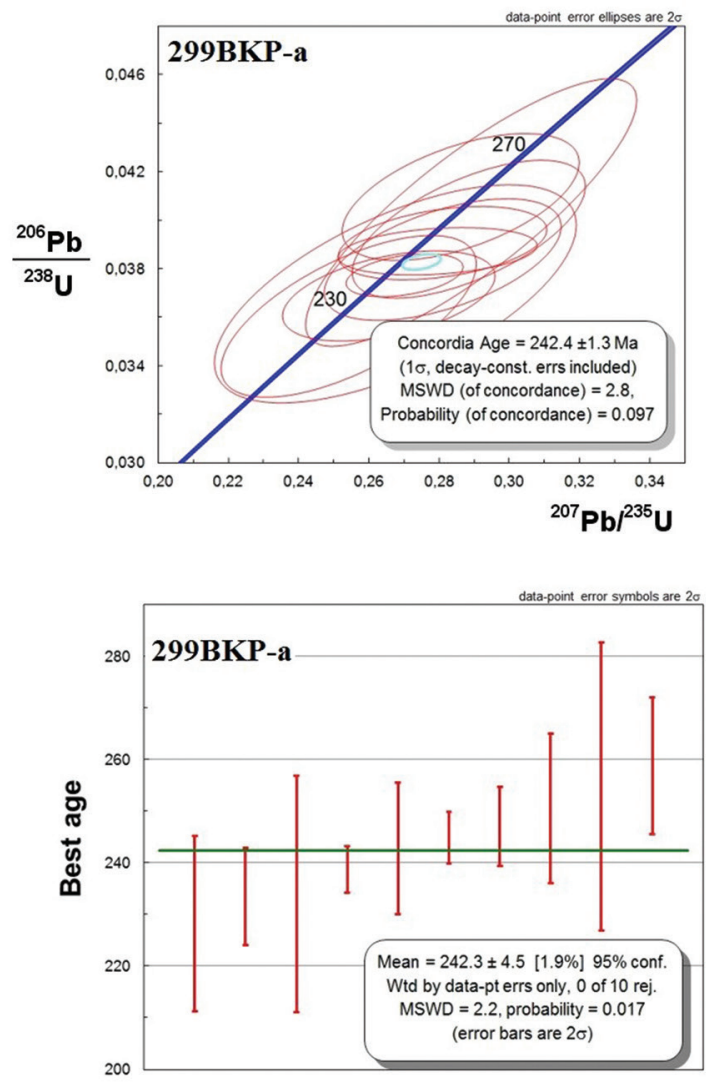
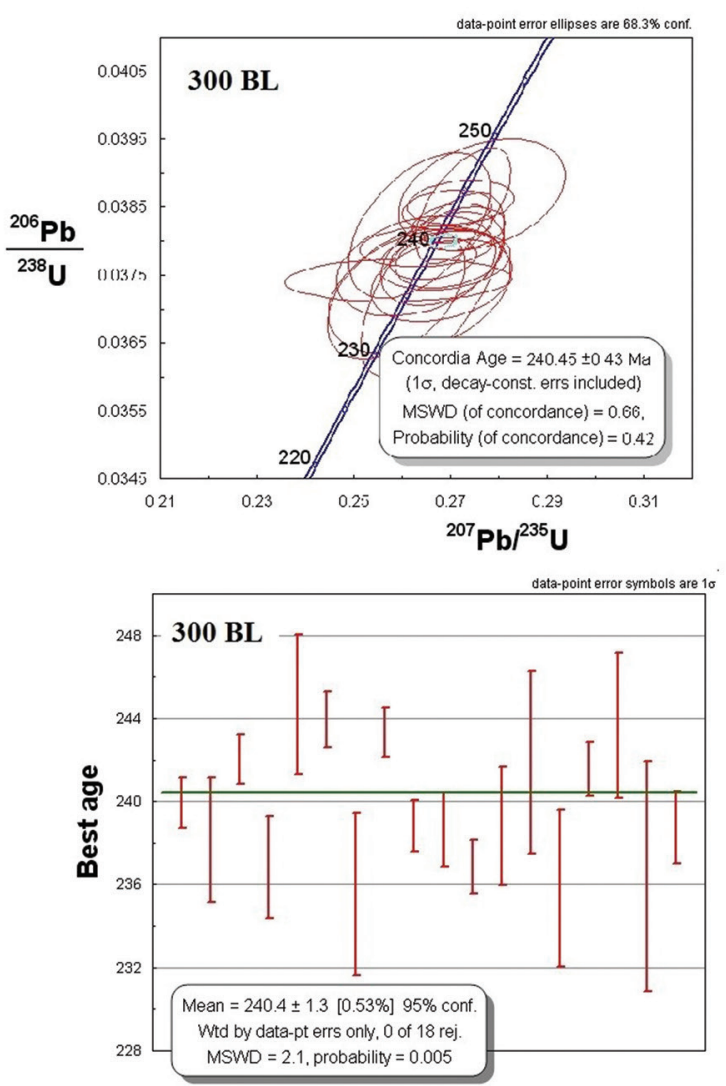

Fig. 17. Isotopic age diagrams for the Krupnik granite (sample 299a) and a foliation-parallel quartzo-feldspathic gneiss (sample 300) within the Rupchos complex.

ples were studied, and their ages are within the range of 87.1-80.8 Ma with an inherited core of 445.3 Ma. A second phase (dioritic porphyrite according to Marchev and Filipov, 2012; subvolcanic-level diorite according to Filipov, 2014) is dated at $71.2 \pm 0.58 \mathrm{Ma}$ on three zircon magmatic grains $(72.1-70.6 \mathrm{Ma})$ from a population of 18 . The inherited cores are dated between 147.2 $\mathrm{Ma}$ and $81 \mathrm{Ma}$, and the xenocrysts between 216.8 Ma and 103.1 Ma. These preliminary results are of obvious interest as far as they may be related with the Late Cretaceous granitoids found in the Rila-West Rhodope batholith situated NNE of them (Kamenov et al., 1999). No rocks of similar composition and ages have been found in the Pirin subunit s.str. up to now.

\section{Spanchevo and Zmeyski granitoids}

The age of the Spanchevo granitoids has been subject of long discussions. The ruling concepts in the last decades of the twentieth century regarded the presence of a superposed foliation in a magmatic body as an indication for a Precambrian or Palaeozoic age. Such an age has been suggested also for the Spanchevo granitoids. On the other hand, K-Ar studies (Boyadjiev and
Lilov, 1972, 1976) yielded rejuvenated dates between $40 \mathrm{Ma}$ and $35 \mathrm{Ma}$.

The Spanchevo granite was studied by the $\mathrm{Rb}-\mathrm{Sr}$ method by S. Moorbath and I. Zagorchev (unpublished, 1983-1987). Unfortunately, the results could not define an isochrone due to the great dispersion of the figurative points on the diagram (Fig. 18), and the ${ }^{87} \mathrm{Sr} /{ }^{86} \mathrm{Sr}$ ratio varied between 0.707 and 0.709 . This variation may be controlled either by the lack of isotopic homogenisation of the $\mathrm{Rb}$-Sr system of the intruding magma due to the incomplete assimilation of the numerous xenoliths of the host gneisses or by opensystem behaviour of this system during post-intrusion superposed deformation. Both options are feasible on geological grounds. Based on the results of the U-Pb determinations, the variation of the initial $\left({ }^{87} \mathrm{Sr} /{ }^{86} \mathrm{Sr}\right)_{i}$ ratios is estimated within the range of $0.7064-0.7076$ (for a mean age of $56 \mathrm{Ma}$ recently obtained by U-Pb zircon studies), i.e., they point at a crustal source of the parental magma.

The first reliable data have been obtained by the LA-ICP-MS method on zircons. Klimov et al. (2009) cited measurements by A. von Quadt and I. Peytcheva of about $55 \mathrm{Ma}$ to $63 \mathrm{Ma}$ with a mean balanced value of 58.4 \pm 1.1 Ma. Jahn-Awe et al. (2010) determined 


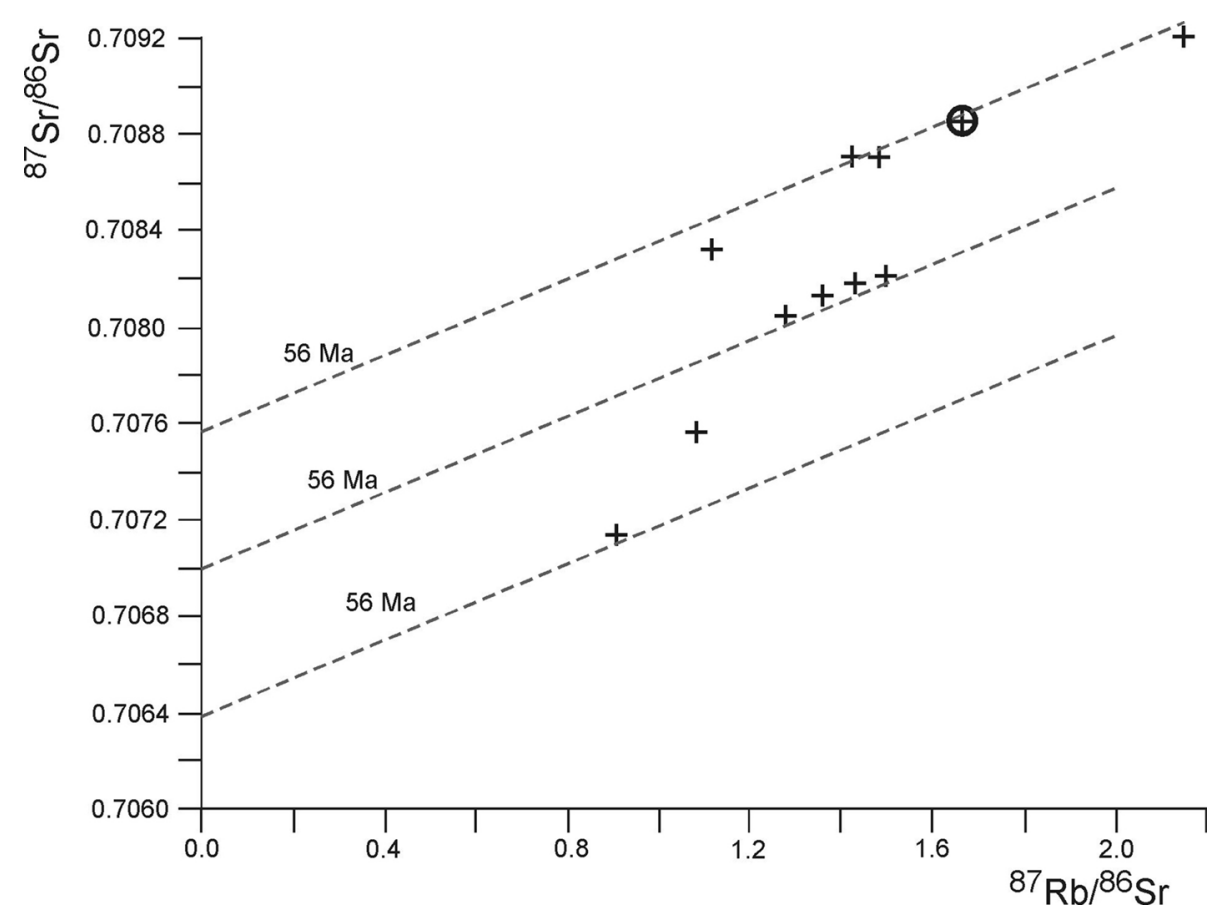

Fig. 18. Rb-Sr diagram for the samples from the Spanchevo granites. Unpublished isotopic data of S. Moorbath (1983-1987).

also a Palaeocene age of $56.0 \pm 0.5 \mathrm{Ma}$. We sampled the pluton at two localities distanced at about $1 \mathrm{~km}$ (samples Sp1 and Sp2, see Table 2), and obtained by the same method similar results of $55.04 \pm 0.24 \mathrm{Ma}$ and $57.23 \pm 0.42 \mathrm{Ma}$ (Fig. 19). Thus, the Palaeocene age of the pluton is confirmed within the range of ca 58-55 Ma. A narrow range of the ages is determined for the individual zircon grains: approximately between $63 \mathrm{Ma}$ and $54 \mathrm{Ma}$. A possible explanation is that the granitoid magma, although containing numerous xenoliths visibly at different degree of resorption and forming numerous inhomogeneous foliationparallel layers and sill-like bodies, has been fully homogenised in respect to $\mathrm{Zr}, \mathrm{U}$, and $\mathrm{Pb}$ (no inherited zircon grains!), and all studied zircon grains have crystallised in situ, during the magma cooling and solidification. On the other hand, individual zircon dates reported by Jahn-Awe et al. (2010) exhibit a small group of four zircon grains dated between $147 \mathrm{Ma}$ and $140 \mathrm{Ma}$. The isotopic and geochemical variations throughout the Spanchevo granitoids are consistent with the results of field and petrological laboratory studies that point at a great variability of the rocks, with presence of anatectic in situ melts, usually fully homogenised with very rare inherited grains, and skialiths/xenoliths at different degrees of melting and/or resorption and homogenisation.

The age of the Zmeyski granitoids was determined by Filipov (2014) on zircons from two samples. The dates cited are $57.08 \pm 0.75 \mathrm{Ma}$ and $56.72 \pm 0.3 \mathrm{Ma}$, respectively, and dating of individual zircon grains yielded data ranging between 140.2 Ma and 54.5 Ma.
Thus, the similarity (Slavov et al., 1976) between the Spanchevo and the Zmeyski granitoids has been confirmed. The range of the inherited grains in the Zmeyski granitoids is larger than that within the Spanchevo granitoids, which is due to a greater homogenisation within the latter.

\section{Bezbog pluton}

The isotopic data on the pluton are scarce. $\mathrm{K}-\mathrm{Ar}$ data were published by Boyadjiev and Lilov (1972). Two samples of Bezbog granite gave K-Ar dates of $36 \mathrm{Ma}$ and $40 \mathrm{Ma}$, respectively, and these dates are similar (within the confidence limits) to the results obtained for the North Pirin, the Central Pirin, and the Teshovo granitoids.

The $\mathrm{Rb}-\mathrm{Sr}$ data recorded by Zagorchev et al. (1987) exhibit a considerable inhomogeneity (see also Zagorchev, 1991). On the grounds of all samples studied, an errorchrone of ca $88 \pm 15 \mathrm{Ma}$ and an initial ${ }^{87} \mathrm{Sr} /{ }^{86} \mathrm{Sr}$ ratio of 0.7107 have been determined. However, S. Moorbath, who performed the analysis of the samples, pointed at the considerable difference between the samples in the two parts of the pluton sampled and that figurative points of each of the two parts might be interpreted as a separate isochrone/errorchrone. These results have been interpreted as the effect of Oligocene events superimposed over the supposedly Late Cretaceous granitoids similarly to mineral isochrones at the background of a whole-rock isochrone. The isochrone for the northern part (quarry on the right bank of the Demyanitsa River) corresponded 

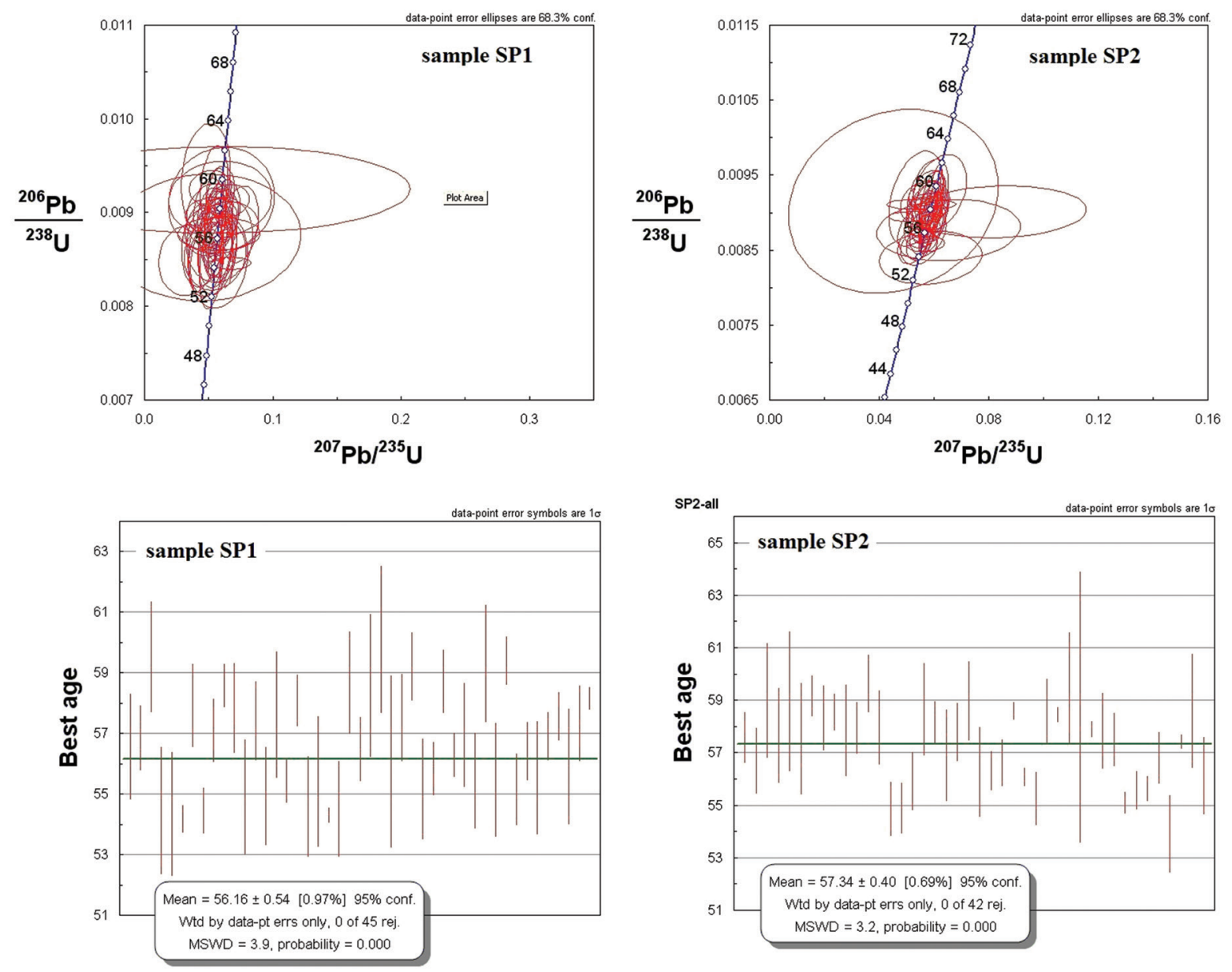

Fig. 19. Isotopic age diagrams for the Spanchevo granite (samples SP1 and SP2).

to an age of $33 \pm 1 \mathrm{Ma}$ and an initial ${ }^{87} \mathrm{Sr} /{ }^{86} \mathrm{Sr}$ ratio of 0.714 , whereas an errorchrone yielded by samples in the southern part (along the road from the village of Pirin towards the mountain hut Pirin) corresponded to ca $40 \mathrm{Ma}$ and an initial ${ }^{87} \mathrm{Sr} /{ }^{86} \mathrm{Sr}$ ratio of 0.712 (see Zagorčev, 1987).

The LA-ICP-MS dates for the Bezbog granite cited by Milovanov et al. (2009) are $34.48 \pm 0.48$ Ma for zircon and 34.7 $\pm 2.7 \mathrm{Ma}$ for monazite. Filipov (2014) obtained an age of $33.14 \pm 0.21 \mathrm{Ma}$ for the porphyric Bezbog granite and $34.06 \pm 0.11 \mathrm{Ma}$ for the coarse-grained granite. Two zircon populations were recorded by him in the coarse-grained granite and, namely, an earlier zircon group (36.8-35.5 Ma) and a late zircon group (34.8-33.4 Ma).

At this stage, the age of the Bezbog pluton may be interpreted as late Priabonian to early Oligocene, and its crystallisation as slightly preceding the intrusion of the granitoids of the Central Pirin pluton. A slight age difference between the northern (Demyanitsa) and the southern part may be considered, too, and this is in accordance with the petrological differences (Machev,
1993 ) and the differences in the above-discussed initial ${ }^{87} \mathrm{Sr} /{ }^{86} \mathrm{Sr}$ ratios.

\section{Granites of Pirin type}

The age of the Pirin-type granites has been subject of $\mathrm{K}-\mathrm{Ar}, \mathrm{Pb}-\mathrm{Pb}, \mathrm{Rb}-\mathrm{Sr}$, and U-Pb studies. The K-Ar studies indicated ages within the range between $32 \mathrm{Ma}$ and $40 \mathrm{Ma}$ (Boyadjiev and Lilov, 1972, 1976). The Rb-Sr studies yielded a 5-point whole-rock isochron for the North Pirin granites (Zagorchev and Moorbath, 1983; Zagorchev et al., 1987) corresponding to $92 \pm 22 \mathrm{Ma}$ and an initial ${ }^{87} \mathrm{Sr} /{ }^{86} \mathrm{Sr}$ ratio of 0.7121 . Aplites both in the Bezbog and the Central Pirin granite were dated by the same method at $37 \pm 2 \mathrm{Ma}$ and initial ${ }^{87} \mathrm{Sr} /{ }^{86} \mathrm{Sr}$ ratio of 0.7115 , and the granites of the Central Pirin pluton at $32 \pm 3 \mathrm{Ma}$ and initial ${ }^{87} \mathrm{Sr} /{ }^{86} \mathrm{Sr}$ ratio of 0.7107 .

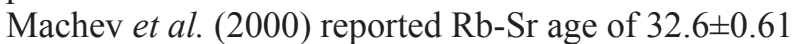
Ma for the South Pirin (Teshovo) granites. Similar Palaeogene (Priabonian-Rupelian) $\mathrm{Pb}-\mathrm{Pb}$ ages were reported by Amov et al. (1982). In the last years, extensive dating by the LA-ICP-MS U-Pb method on zir- 

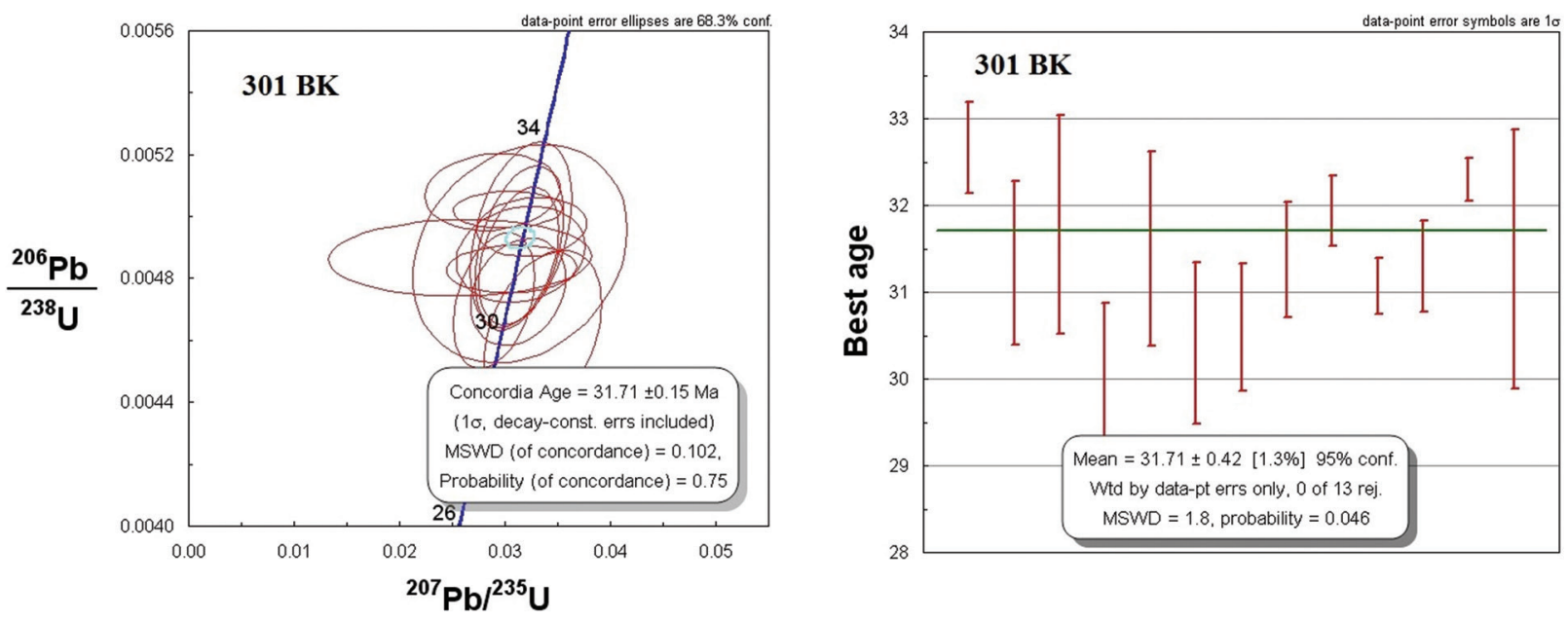

Fig. 20. Isotopic age diagrams for the North Pirin (Kresna) granite (sample 301).

cons has been performed and reported (Klimov et al., 2009; Milovanov et al., 2009, 2010; Jahn-Awe et al., 2010; Filipov and Marchev, 2011, 2012; Georgiev et al., 2011, 2012; Filipov et al., 2012; Zagorchev et al., 2012; Filipov, 2014). The reliable dates vary within a narrow range: from ca $35 \mathrm{Ma}$ to $31.7 \mathrm{Ma}$ (Table 2).

A sample from the North Rhodope (Dautov, Kresna) pluton has been taken (Zagorchev et al., 2012) along the road E-79 in the Kresna Gorge near the first tunnel. An early Oligocene age of $31.71 \pm 0.15 \mathrm{Ma}$ (Fig. 20) has been determined. A number of inherited zircons preserved as cores or inner rims of zircon grains range from Ediacaran (ca $560 \mathrm{Ma}$ ) to Late Hercynian, with a few Jurassic dates but no Cretaceous dates. Even a wider range (between ca $1200 \mathrm{Ma}$ to ca $110 \mathrm{Ma}$ ) was reported by Georgiev et al. (2012). The sound conclusion of these authors is that "the origin of the magmatic rocks studied is strongly influenced by this thick crust, either by different degrees of melting or a high rate of assimilation."

The comparison between the abundant geochemical and isotopic information on Bulgarian and Greek territories, together with field observations and petrological studies, points at a complex process of magma mixing and mingling (Christofides et al., 1998; Machev and Rashkova, 2000; Machev et al., 2000) of magmas of mantle and of crustal origin, with a different degree of assimilation of host rock xenoliths. The pronounced increase of the initial ${ }^{87} \mathrm{Sr} /{ }^{86} \mathrm{Sr}$ ratios from the south to the north and the petrological observations revealing a decrease of the enclaves of basic rocks in the same direction indicate a decreasing role of the mantle contribution from the area of comparatively thin to that of thickened continental crust, as already pointed out for the Palaeogene lavas (Zagorčev, 1971; Harkovska et al., 1987; Georgiev et al., 2012; Filipov, 2014).

\section{CONCLUSIONS}

The isotopic geochronological studies on the metamorphic rocks of the Rhodopian supercomplex in the Pirin Subunit of the lower (Pirin-Pangaion) Unit of the Rhodope Massif are still insufficient for a full and well-grounded revision of the Pirin and Rhodopes multistage tectonometamorphic evolution. This conclusion concerns, to a major degree, the pre-Jurassic distribution of the major events that is compared to the adjacent units (Fig. 21). Some of the obtained data are controversial. The areal and lithostratigraphic distribution of the samplings performed is not sufficiently representative.

The still scarce isotopic data may be interpreted by different manners that are greatly influenced by the theoretical background and ideas of the interpreters. However, the following facts may be regarded as proven:

(1) Cadomian (Ediacaran-Cambrian; 528-517 Ma) metamorphism, anatexis, and granitoid igneous activity are proven in the Rupchos Group (complex) within the Krupnik area. Similar events of the same age have also been recorded in the Ograzhden and Vertiskos units, and in the other (Central Rhodope, Eastern Rhodope) units of the Rhodope Massif, (in the Ograzhdenian, Prerhodopian, and Rhodopian rock units).

(2) Ordovician tectonometamorphic reworking is demonstrated within the Obidim area but still has not been recorded in the Pirin-Pangaion Unit. Such reworking is dominant within the Ograzhden and Veriskos units.

(3) Hercynian metamorphic reworking, anatexis, and granitoid activity are found in all three areas studied. The principal events occurred within the interval 330-290 Ma. They are common in the other units of the Rhodope Massif. The late (Triassic, 250-235 Ma) granitoid magmatism in the Krupnik area is common 


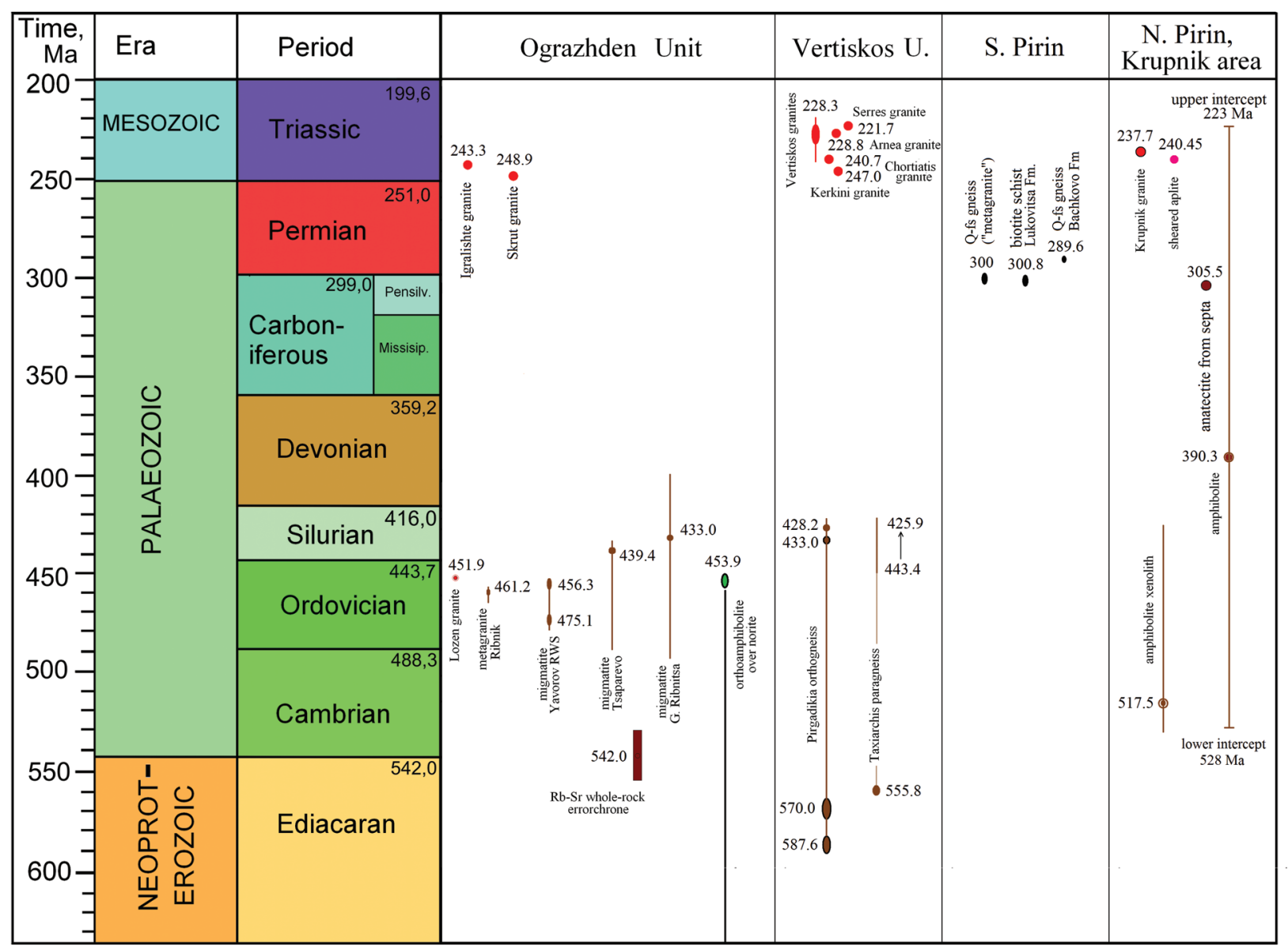

Fig. 21. Comparative time chart for the metamorphic and igneous events in the Ograzhden and Vertiskos units and the Pirin Subunit of the Pirin-Pangaion Unit from Ediacaran to Triassic time. After different sources.

in the adjacent units (Ograzhden and Vertiskos) of the Serbo-Macedonian Massif and is recorded as a late phase of the Hercynian granitoid activity in the Srednogorie zone.

(4) Mesozoic (Jurassic?) overprint is suggested for the Obidim area (Peycheva et al., 2009; Sarov et al., 2011). It is known also from different parts of the Central and Eastern Rhodopes in Bulgaria and Greece but still unknown in the Pirin subunit. Late Cretaceous basic to intermediate plutonic activity is reported for the same area on the basis of preliminary data (Filipov, 2014).

(5) The Spanchevo-type granitoids (Spanchevo and Zmeyski plutons) are related to a Palaeocene-early Eocene (58-55 Ma) phase of anatexis and intrusive activity that occurred within the thickened Rhodope crust. These granitoids have been formed almost in situ, within rocks with variable chemical and isotopic content, and in open-system conditions. Granitoids of the same age are recorded in the southern parts of the Central Rhodopes, too (Marchev et al., 2013).

(6) The thrusting (or at least the latest thrusting phase) of the Ograzhden Unit over the Pirin Subu- nit along the Strimon Thrust, previously (Zagorčev, 1994a) supposed to be of mid-Cretaceous age, is now referred to mid-Eocene times due to the presence of related compressive deformations and superimposed schistosity within the Palaeocene-early Eocene Spanchevo pluton.

(7) Late HT-LP overprint (andalusite-bearing paragenesis; continuous crystallisation or thermal "rejuvenation" of monazite) is related to the Palaeogene exhumation and granitoid activity.

(8) The Bezbog pluton is now regarded as an early phase intrusion of Pirin-type granite magma.

(9) The Pirin-type granitoids are referred to a granitoid association formed by mixing and mingling of basic magma of mantle origin and crust-derived anatectic magma. Zonality is established, with increase of the crustal components from south to north. This zonality corresponds to the gradual northward increase of the crustal thickness. The association is a part of a Mesta-Pirin volcano-plutonic association within the late Eocene-early Oligocene Macedonian-Rhodope magmatotectonic province. 
The future isotopic studies should be concentrated at least on the following rock units and areas: (1) several generations of anatexites (migmatites and diatexites) in the Krupnik area, and attempt for a final solution of the controversial data regarding the Krupnik granite must be made; (2) two generations of metabasic rocks north of the town of Kresna and metabasics and metapelites of the Rupchos Group in the West-Pirin (Lilyanovo) area; (3) different rock varieties (metabasics, metapelites, gneisses) of the Rupchos Group of the South-Pirin area; (4) gneisses and metapelites of the Lukovitsa Formation in the South Pirin area with detailed petrological studies; (5) all suitable rock varieties of the Boykovo-Bachkovo and Lukovitsa formations within the Sinanitsa area, with special emphasis on the anatectic processes; (6) The metabasites and the gneisses in the Obidim area (Bogutevo Formation?) and their relations with the rocks of the West Rhodope Unit. Further isotopic studies should be made on the magmatic rocks as, e.g., the basic rocks in the Obidim area (Kremen diorites). Another problem concerns the discrepancies between the $\mathrm{Rb}-\mathrm{Sr}$ whole-rock determinations and the $\mathrm{U}-\mathrm{Pb}$ zircon results within the Dautov pluton.

\section{Acknowledgements}

The present research was performed within the projects "Geology of Bulgaria" (Geological Institute, Bulgarian Academy of Sciences), the bilateral project of the Bulgarian Academy of Sciences and the Romanian Academy "Principal tectonometamorphic events in the basement of the South Carpathian and the Balkan orogens", and the ID-480 grant and PN-II-IDPCE-2011-3-0100 project awarded to I. Balintoni by CNCS - UEFISCDI units of the Romanian National Authority for Scientific Research. The detailed reviews with useful suggestions by Irena Peytcheva and Yanko Gerdjikov are gratefully acknowledged. Special thanks are due to the Chief Editor of Geologica Balcanica, Lubomir Metodiev, for his efforts to improve the manuscript.

\section{APPENDIX. SUPPLEMENTARY DATA}

Supplementary data to this article can be found online at https://www.geologica-balcanica.eu/sites/default/ files/supplementary/Zagorchev_Geol_Balc 46-1 Supplementary data.pdf.

\section{REFERENCES}

Amov, B., Arnaudov, V., Pavlova, M. 1982. Lead isotope data and age of granitoids and metamorphic rocks from Sredna Gora and Pirin. Comptes rendus de l'Académie bulgare des Sciences 35, 1535-1537.

Arnaudova, R., Arnaudov, V. 1982. Comparative geochemistry and conditions of formation of the "South Bulgarian granites". Geologica Balcanica 12 (4), 21-36 (in Russian, with English abstract).

Boyadjiev, S. 1959. On the geology of Pirin Mountain. Annuaire de la Direction des Recherches Géologiques et Minières 8, 89-125 (in Bulgarian).

Boyadjiev, S. 1989. Petrology of the Pirin granitoids. Geologica Balcanica 19 (2), 55-87 (in Russian, with English abstract).

Boyadjiev, S.G. 1991. Geochemistry of rare-earth elements in the Pirin granitoids. Geochemistry, Mineralogy and Petrology 27, 1-24 (in Bulgarian, with English summary).

Boyadjiev, S., Lilov, P. 1972. On the data over the granites of the Pirin horst-anticlinorium obtained by the K-Ar method. Annual of the State Enterprise "Geological Research" 20 (1971), 219-225 (in Bulgarian, with English summary).

Boyadjiev, S., Lilov, P. 1976. Data obtained by the K/Ar method on the South-Bulgarian granitoids in the Western Rhodope Block and the Kraishtides. Review of the Bulgarian Geological Society 37, 161-169 (in Bulgarian).

Brown, M. 2013. Granites: From formation to emplacement. GSA Bulletin 125 (7/8), 1079-1113.

Brun, J.-P., Sokoutis, D. 2007. Kinematics of the Southern Rhodope Core Complex (North Greece). International Journal of Earth Sciences 96 (6), 1079-1099.
Bucher, K., Frey, M. 1994. Petrogenesis of Metamorphic Rocks ( $6^{\text {th }}$ Edition. Complete Revision of Winkler's Textbook). Springer, Berlin, $318 \mathrm{pp}$.

Bucher, K., Grapes, R. 2011. Petrogenesis of Metamorphic Rocks ( $8^{\text {th }}$ Edition). Springer, Berlin; 428 pp.

Burchfiel, B.C., Nakov, R., Tzankov, T., Royden, L. 2000. Cenozoic extension in Bulgaria and Northern Greece: the northern part of the Aegean extensional regime. In: Bozkurt, E., Winchester, J.A., Pe-Piper, J.D.A. (Eds), Tectonics and Magmatism in Turkey and the Surrounding Area. Geological Society London, Special Publications 173, 325-352.

Burchfiel, B.C., Nakov, R., Tzankov, T. 2003. Evidence from the Mesta half-graben, SW Bulgaria, for the Late Eocene beginning of Aegean extension in the Central Balkan Peninsula. Tectonophysics 375 (1-4), 61-76.

Burg, J.-P. 2011. Rhodope: From Mesozoic convergence to Cenozoic extension. Review of petro-structural data in the geochronological frame. In: Skourtsos, E., Lister, G. (Eds), The Geology of Greece. Journal of the Virtual Explorer, Electronic Edition, 42, paper 1.

Burg, J.-P., Ricou, L.-E., Ivanov, Z., Godfriaux, I., Dimov, D., Klain, L. 1996a. Syn-metamorphic nappe complex in the Rhodope Massif. Structure and kinematics. Terra Nova 8 (1), 6-15.

Burg, J.-P., Klain, L., Ivanov, Z., Ricou, L.-E., Dimov, D. 1996b. Crustal-scale thrust complex in the Rhodope Massif. Evidence from structures and fabrics. In: Nairn, A.E.M., Ricou, L.-E., Vrielynck, B., Dercourt, J. (Eds), The Ocean Basins and Margins: the Tethys Ocean. Plenum Publishing Corporation, New York, 125-149. 
Christofides, G., Soldatos, T., Eleftheriadis, G., Koroneos, A. 1998. Chemical and isotopic evidence for source contamination and crustal assimilation in Hellenic Rhodope plutonic rocks. Acta Vulcanologica 10, 305-318.

Christofides, G., Koroneos, A., Pipera, K., Poli, G., Soldatos, T. 2014. Geochemical constraints on the origin and evolution of the Xanthi Plutonic Complex (Rhodope Massif, N Greece. Buletini i Shkenkave Gjeologjike 1, Special Issue, Proceedings of the XX CBGA Congress, Tirana, 428-431.

Dabovski, C., Boyanov, I., Khrischev, K., Nikolov, T., Sapounov, I., Yanev, Y., Zagorchev, I. 2002. Structure and Alpine evolution of Bulgaria. Geologica Balcanica 32 (2-4), $9-15$.

Del Moro, A., Innocenti, F., Kyriakopoulos, C., Manetti, P., Papadopoulos, P. 1988. Tertiary granitoids from Thrace (Northern Greece): Sr isotopic and petrochemical data. Neues Jahrbuch für Mineralogie, Abhandlungen 159, 113-135.

Dimitrov, C. 1957. Notes on the Xanthi pluton. Annuaire de l'Université de Sofia, Faculté de Géologie et Géographie, Géologie 49, 35-63 (in Bulgarian).

Dimitrov, S. 1959. Kurze Übersicht der metamorphen Komplexe in Bulgarien. Freiberger Forschungshefte Reihe C., Heft 57, 62-72.

Dimitrova, E. 1971. Petrology of the metamorphic basement of Pirin Mountain. Bulletin of the Geological Institute, Series Geochemistry, Mineralogy, Petrography 20, 181-217 (in Bulgarian, with German summary).

Dimitrova, E., N. Sarafova. 1968. Formation of the porphyritic facies of Central Pirin granite. Bulletin of the Geological Institute, Series Geochemistry, Mineralogy, Petrography 17, 269-281 (in Bulgarian, with German summary).

Dinter, D.A., Royden, L. 1993. Late Cenozoic extension in northeastern Greece: Strymon Valley detachment system and Rhodope metamorphic core complex. Geology 21 (1), 45-48.

Dinter, D.A., MacFarlane, A., Hames, W., Isachsen, C., Bowring, S., Royden, L. 1995. U-Pb and ${ }^{40} \mathrm{Ar} /{ }^{39} \mathrm{Ar}$ geochronology of the Symvolon granodiorite: Implications for the thermal and structural evolution of the Rhodope metamorphic core complex, northeastern Greece. Tectonics 14 (4), 886-908.

Filipov, P. 2014. Petrology, geochemistry, geochronology of the Mesta volcanic complex and the Central Pirin granite batholith. Abstract of $\mathrm{PhD}$ thesis, Geological Institute Sofia, $52 \mathrm{pp}$. (in Bulgarian).

Filipov, P., Marchev, P. 2011. U-Pb zircon and ${ }^{40} \mathrm{Ar} /{ }^{39} \mathrm{Ar}$ ages of Mesta volcanic rocks and Central Pirin pluton. Bulgarian Geological Society, National Conference with International Participation "Geosciences 2011”, Abstracts, 49-50.

Filipov, P., Marchev, P. 2012. U-Pb zircon geochronology of Central Pirin batholith. Bulgarian Geological Society, National Conference with International Participation "Geosciences 2012", Abstracts, 41-42.

Filipov, P., Marchev, P., Müncker, C., Kirchenbaur, M. 2012. Preliminary data on the age and geochemistry of Mesta volcanic complex and Central Pirin pluton. SCOPES Project - Conference and Field Trip: Serbia and Macedonia.

Filipov, P., Marchev, P., Peytcheva, I., Müncker, C., Kirchenbaur, M. 2014. Comparison between ${ }^{176} \mathrm{Hf} /{ }^{177} \mathrm{Hf}$ of zircon and whole rock samples from Mesta Volcanic Complex, West Rhodopes: Evidence for crustal contamination. $\mathrm{Bu}$ letini i Shkenkave Gjeologjike 1, Special Issue, Proceedings of the XX CBGA Congress, Tirana, 433-436.

Georgiev, G.K. 1973. On the relationships between the equigranular and porphyroid granitoids in the Pirin Mountain. Annual of Higher Institute of Mining and Geology 19 (2), 151-155 (in Bulgarian).
Georgiev, S., Grozdev, V., von Quadt, A., Peytcheva, I., Marchev, P. 2011. Temporal evolution of the Cenozoic magmatism in WSW Bulgaria and SE Macedonia; crustal thickness control on zircon populations and whole-rock $87 \mathrm{Sr} / 86 \mathrm{Sri}-143 \mathrm{Nd} / 144 \mathrm{Ndi}$ ratios. Bulgarian Geological Society, National Conference with International Participation "Geosciences 2011", 51-52.

Georgiev, S., Peytcheva, I., von Quadt, A., Marchev, P., Grozdev, V., Balkanska, E. 2012. North Pirin pluton and the volcanic and subvolcanic rocks between the villages of Padesh and Kresna: an example of high rate of crustal assimilation. The school of Prof. Zhivko Ivanov, International Conference, Sofia, 4 pp.

Harkovska, A., Yanev, Y., Marchev, P. 1989. General features of the Palaeogene orogenic magmatism in Bulgaria. Geologica Balcanica 19 (1), 37-72.

Imperial College London. 2013. Glossary: metamorphic facies (https://wwwf.imperial.ac.uk/earthscienceandengineering/ rocklibrary/viewglossrecord.php?Term=metamorphic $\% 20$ facies).

Jahn-Awe, S., Froitzheim, N., Nagel, T.J., Frei, D., Georgiev, N., Pleuger, J. 2010. Structural and geochronological evidence for Paleogene thrusting in the western Rhodopes, SW Bulgaria: Elements for a new tectonic model of the Rhodope Metamorphic Province. Tectonics 29 (3), TC3008, doi:10.1029/2009TC002558.

Janák, M., Froitzheim, N., Georgiev, N., Nagel, T.J., Sarov, S. 2011. P-T evolution of kyanite eclogite from the Pirin Mountains (SW Bulgaria): implications for the Rhodope UHP Metamorphic Complex. Journal of Metamorphic Geology 29, 317-332.

Kamenov, B., Peytcheva, I., Klain, L., Arsova, K., Kostitsin, Yu., Salnikova, E. 1999. Rila-West Rhodopes Batholith: Petrological and geochemical constraints for its composite character. Geochemistry, Mineralogy and Petrology 36, 3-27.

Katzkov, N., Marinova, R. 1992. Explanatory note for the geological map of the Republic of Bulgaria in scale 1:100 000, Belitsa map sheet. Committee of Geology, Sofia, 43 pp. (in Bulgarian, with English abstract).

Klimov, I., Marinova, R., Marinova, A., Petrov, I. 2009. Geological map of the Republic of Bulgaria in scale 1:50 000, K-34-95-B (Sandanski) map sheet; Explanatory note for the geological map of the Republic of Bulgaria in scale 1:50 000, K-34-95-B (Sandanski) map sheet. Ministry of environment and waters, Bulgarian National Geological Survey, Sofia, $58 \mathrm{pp}$.

Klimov, I., Marinova, R., Marinova, A., Petrov, I. 2009. Geological map of the Republic of Bulgaria in scale 1:50 000, K-34-95-V (Katuntsi) map sheet; Explanatory note for the geological map of the Republic of Bulgaria in scale 1:50 000, K-34-95-V (Katuntsi) map sheet. Ministry of environment and waters, Bulgarian National Geological Survey, Sofia, $48 \mathrm{pp}$.

Klimov, I., Marinova, R., Marinova, A., Petrov, I., Valev, V. 2009. Geological map of the Republic of Bulgaria in scale 1:50 000, K-34-96-V (Petrovo) map sheet; Explanatory note for the geological map of the Republic of Bulgaria in scale 1:50 000, K-34-96-V (Petrovo) map sheet. Ministry of environment and waters, Bulgarian National Geological Survey, Sofia, $48 \mathrm{pp}$.

Klimov, I., Marinova, R., Marinova, A., Petrov, I., Valev, V. 2009. Geological map of the Republic of Bulgaria in scale 1:50 000, K-34-96-A (Gotse Delchev) map sheet; Explanatory note for the geological map of the Republic of Bulgaria in scale 1:50 000, K-34-96-A (Gotse Delchev) map sheet. Ministry of environment and waters, Bulgarian National Geological Survey, Sofia, 63 pp. 
Klimov, I., Marinova, A., Marinova, R., Petrov, I., Milovanov, P., Ilieva, P. 2009. Geological map of the Republic of Bulgaria in scale 1:50 000, K-34-94-G (Makrievo), K-34-95-V(Petrich), K-34-106-B, K-34-107-A (Belasitsa) map sheets; Explanatory note for the geological map of the Republic of Bulgaria in scale 1:50 000, K-34-94-G (Makrievo), K-3495-V-(Petrich), K-34-106-B, K-34-107-A (Belasitsa) map sheets. Ministry of environment and waters, Bulgarian National Geological Survey, $63 \mathrm{pp}$.

Kockel, F., Walther, H.W. 1965. Die Strimonlinie als Grenze zwischen Serbo-Mazedonischen und Rila- Rhodope-Massiv in Ost-Mazedonien. Geologisches Jahrbuch 83, 57-602.

Kolocotroni C., Dixon, J.E. 1991. The origin and emplacement of the Vrondou granite, Serres, N.E. Greece. Bulletin of the Geological Society of Greece 25 (1), 469-483.

Kozhoukharov, D. 1984. Lithostratigraphy of the Precambrian metamorphic rocks of the Rhodopian Supergroup in the Central Rhodope Mts. Geologica Balcanica 14 (1), 43-88 (in Russian, with English abstract).

Kozhoukharov, D. 1986. Interregional correlations of the Precambrian in the southern parts of the Balkan Peninsula. Geologica Carpathica 37 (3), 317-333.

Kozhoukharov, D. 1994. Precambrian microphytofossils in Boz Dag and Menikio-Kavala series, Northern Greece. Comptes rendus de l'Académie bulgare des Sciences 47 (3), 67-70.

Kozhoukharov, D., Konzalova, M. 1990. First finds of microphytofossils in the marbles of the Dobrostan Formation in Northern and Southern Pirin. Geologica Balcanica 20 (2), $47-52$.

Kozhoukharov, D., Marinova, R. 1991. Explanatory note for the geological map of the Republic of Bulgaria in scale 1:100 000, Gotse Delchev map sheet. Committee of Geology and Mineral Resources, Geology and Geophysics Ltd, Sofia, 57 pp. (in Bulgarian, with English abstract).

Kozhoukharov, D., Marinova, R. 1991. Geological map of Republic of Bulgaria in scale 1:100 000, Gotse Delchev map sheet. Committee of Geology and Mineral Resources, Geology and Geophysics Ltd.

Kozhoukharov, D., Kozhoukharova, E., Papanikolaou, D. 1988. Precambrian in the Rhodope Massif. In: Zoubek, V., Cogné, J., Kozhoukharov, D., Kräutner, H.G. (Eds), Precambrian in younger fold belts - European Variscides, the Carpathians and Balkans. John Willey, Chichester, 723778.

Kozhoukharova, E. 1980. Eclogites in the Precambrian from the Eastern Rhodope block. Comptes rendus de l'Académie bulgare des Sciences 33 (3), 375-378.

Ludwig, K.R. 1980. Calculation of uncertainties of U-Pb isotope data. Earth and Planetary Science Letters 46, 212 220.

Ludwig, K.R. 2001. User's Manual for Isoplot/Ex, Version 3.0. A geochronological toolkit for Microsoft Excel. Berkeley Geochronology Center Special Publication 4, 71 pp.

Machev, Ph. 1993a. Petrology of the Central Pirin pluton. Review of the Bulgarian Geological Society 54 (1), 123-137 (in Bulgarian, with English summary).

Machev, Ph. 1993b. Petrology of the Spanchevo pluton. S-type granites from Central Pirin Mountain. Annuaire de l'Université de Sofia, Faculté de géologie et géographie, Géologie 85, 53-72 (in Bulgarian, with English summary).

Machev, Ph., Hecht, L. 2008. Pl-Spl coronas around kyanite - evidence for HT (granulite facies) metamorphism in the metapelites from the Western slope of Pirin Mnt. (SerboMacedonian massif). Bulgarian Geological Society, National Conference with International Participation "Geosciences 2008", Abstracts, 51-52.

Machev, Ph., Hecht, L., Klain, L., Atanasov, V. 2005. P-T evolution of the metapelites from the western slope of the Pirin
Mountain. Bulgarian Geological Society, Jubilee International Conference "80 years Bulgarian Geological Society", Abstracts, 134-137.

Machev, Ph., Klain, L. 2000. Syntectonical granitoid magmatism in Northern Pirin and Maleshevska mountains - Krupnik pluton or Krupnik granite. Annuaire de l'Université de Sofia, Faculté de géologie et géographie, Géologie 92, 147-157.

Machev, Ph., Ovcharova, M. 2008. Metamorphosed Hercynian granites from Western Pirin Mountain. Sofia University "St Kliment Ohridski”, 60 years subject Geology, 115-121.

Machev, Ph., Rashkova, G. 2000. Magma mingling and mixing in the Teshovo granitoid pluton (South Pirin Mountain, Bulgaria). I. Field and petrological evidence. Annuaire de l'Université de Sofia, Faculté de géologie et géographie, Géologie 93 (1), 143-161.

Machev, Ph., Peytcheva, I., Kostitsyn, Y., Rashkova, G. 2000. Magma mingling and mixing in the Teshovo granitoid pluton (South Pirin Mountain, Bulgaria). II. Isotope-geochemical evidence. Annuaire de l'Université de Sofia, Faculté de géologie et géographie, Géologie 93, 163-172.

Machev, Ph., Veit, B. 2001. Metamorphosed basic rocks from the Western slope of Pirin Mountain (Serbo-Mazedonian massif) - tectonic setting and metamorphic history. Annuaire de l'Université de Sofia, Faculté de géologie et géographie, Géologie 94, 135-153.

Marchev, P., Filipov, P., 2012. First findings of Late Cretaceous magmatic rocks in the Pirin Mts. Bulgarian Geological Society, National conference. Bulgarian Geological Society, National Conference with International Participation “Geosciences 2012”, Abstracts, 55-56.

Marchev, P., Georgiev, S., Raicheva, R., Peytcheva, I., von Quadt, A., Ovtcharova, M., Bonev, N. 2013. Adakitic magmatism in post-collisional setting: An example from the Early-Middle Eocene Magmatic Belt in Southern Bulgaria and Northern Greece. Lithos 180-181, 159-180.

Marinova, R., Katzkov, N. 1990. Geological map of the Republic of Bulgaria in scale 1:100 000, Belitsa map sheet. Committee of Geology and Mineral Resources, Geology and Geophysics Ltd.

Marinova, R., Zagorčev, I. 1990. Geological map of the Republic of Bulgaria in scale 1:100 000, Razlog map sheet. Committee of Geology and Mineral Resources, Geology and Geophysics Ltd.

Marinova, R., Zagorčev, I. 1993. Explanatory note for the geological map of the Republic of Bulgaria in scale 1:100 000, Razlog map sheet. Committee of Geology and Mineral Resources, Geology and Geophysics Ltd, 62 pp. (in Bulgarian, with English abstract).

Maruyama, S., Okamoto, K. 2007. Water transportation from the subducting slab into the mantle transition zone. Gondwana Research 11, 148-165.

Massonne, H.-J. 2016. Tertiary high-pressure metamorphism recorded in andalusite-bearing micaschist, southern Pirin Mts., SW Bulgaria. European Journal of Mineralogy, doi:10.1127/ejm/2016/0028-2575.

Miller, C.V., McDowell, S.M., Mapes, R.W. 2003. Hot and cold granites? Implications of zircon saturation temperatures and preservation of inheritance. Geology 31 (6), 529-532.

Milovanov, P., Petrov, I., Marinova, A., Ilieva, E., Peytcheva, I., von Quadt, A., Pristavova, S. 2010. New geological and geochronological data of granititic and metamorphic rocks from SW Bulgaria, sheets Berovo (K-34-82-G) and Kresna (K-34-83-W) of the new geological map 1:50 000. Geologica Balcanica, 39 (1-2), p. 256.

Milovanov, P., Klimov, I., Petrov, I., Valev, V., Marinova, A., Sinnyovsky, D., Ichev, M., Ilieva, E. 2009. Geological map of the Republic of Bulgaria in scale 1:50 000, K-34-83-B 
(Razlog) map sheet; Explanatory note for the geological map of the Republic of Bulgaria in scale 1:50 000, K-34-83-B (Razlog) map sheet. Ministry of Environment and Waters, Bulgarian National Geological Survey, Sofia, 68 pp.

Milovanov, P., Petrov, I., Marinova, A., Valev, V., Klimov, I., Sinnyovsky, D., Ichev, M., Ilieva, E. 2009. Geological map of the Republic of Bulgaria in scale 1:50 000, K-34-83-G (Bansko) map sheet; Explanatory note for the geological map of the Republic of Bulgaria in scale 1:50 000, K-3483-G (Bansko) map sheet. Ministry of Environment and Waters, Bulgarian National Geological Survey, Sofia, 60 pp.

Milovanov, P., Petrov, I., Valev, V., Klimov, I., Marinova, A., Zelev, V., Sinnyovsky, D., Ichev, M., Ilieva, E. 2009. Geological map of the Republic of Bulgaria in scale $M$ 1:50 000, K-34-82-G (Berovo) and K-34-83-B (Kresna) map sheets; Explanatory note for the geological map of the Republic of Bulgaria in scale 1:50 000, K-34-82-G (Berovo) and K-34-83-B (Kresna) map sheets. Ministry of Environment and Waters, Bulgarian National Geological Survey, Sofia, $76 \mathrm{pp}$.

Milovanov, P., Petrov, I., Zelev, V., Sinnyovsky, D., Marinova, A., Klimov, I., Valev, V., Ichev, M., Ilieva, E. 2009. Geological map of the Republic of Bulgaria in scale M 1:50 000, K-34-82-B (Delchevo) and K-34-83-A (Simitli) map sheets; Explanatory note for the geological map of the Republic of Bulgaria in scale 1:50 000, K-34-82-B (Delchevo) and K-34-83-A (Simitli) map sheets. Ministry of Environment and Waters, Bulgarian National Geological Survey, Sofia, $108 \mathrm{pp}$.

Okamoto, K., Maruyama, S. 1999. The high pressure stability limits of lawsonite in the MORB $+\mathrm{H}_{2} \mathrm{O}$ system. American Mineralogist 84, 362-373.

Perugini, D., Poli, G., Christofides, G., Eleftheriadis, G., Koroneos, A., Soldatos, T. 2004. Mantle-derived and crustal melts dichotomy in northern Greece: spatiotemporal and geodynamic implications. Geological Journal 39, 63-80.

Petrik, I., Janak, M., Froitzheim, N., Georgiev, N., Yoshida, K., Sasinkov, V., Konečny, A.P., Milovska, S. 2016. Triassic to Early Jurassic (c. $200 \mathrm{Ma}$ ) UHP metamorphism in the Central Rhodopes: evidence from U-Pb-Th dating of monazite in diamond-bearing gneiss from Chepelare (Bulgaria). Journal of Metamorphic Geology 34, 265-291.

Peytcheva, I., von Quadt, A., Sarov, S., Voynova, E., Kolcheva, K. 2009. Ordovician protoliths of metamorphic rocks in Eastern Pirin-Western Rhodopes: Are they part of the Ograzhden Unit?. Bulgarian Geological Society, National Conference with International Participation "Geosciences 2009", Abstracts, 17-18.

Sarov, S. 2012. Lithotectonic subdivision of the metamorhic rocks in the area of Rila and Rhodope Mountains - results from geological mapping at scale 1:50 000. The school of Prof. Zhivko Ivanov, International Conference, Sofia.

Sarov, S., Georgiev, N., Naidenov, K., Voinova, E., Kolcheva, K. 2008. Lithotectonic subdivision of the Western Rhodopes and parts of Eastern Pirin. Bulgarian Geological Society, National Conference with International Participation “Geosciences 2008”, Abstracts, 89-90.

Sarov, S., Moskovski, S., Zhelezarski, T., Georgiev, N., Voynova, E., Marinova, A., Nikolov, D., Georgieva, E., Markov, N. 2010. Geological map of the Republic of Bulgaria in scale 1:50 000, K-34-84-V (Dobrinishte) map sheet. Ministry of Environment and Waters, Bulgarian National Geological Survey, Sofia.

Sarov, S., Moskovski, S., Zhelezarski, T., Georgiev, N., Voynova, E., Nikolov, D., Georgieva, E., Markov, N. 2011. Geological map of the Republic of Bulgaria in scale 1:50 000, K-34-84-A (Belitsa) map sheet. Ministry of Environment and Waters, Bulgarian National Geological Survey, Sofia.
Slavov, I., Zagorčev, I., Zidarov, N., Šabatov, Y., Valčev, V., Todeva, M., Hristov, S. 1976. On some geological features of the granitoids in Pirin mountain. Annuaire de l'Université de Sofia, Faculté de géologie et géographie, Géologie 68, 107-128 (in Bulgarian, with English abstract).

Sokoutis, D., Brun, J.-P., Van Den Driessche, J., Pavlides, S. 1993. A major Oligo-Miocene detachment in southern Rhodope controlling north Aegean extension. Journal of the Geological Society of London 150 (2), 243-246.

Soldatos, T., Koroneos, A., Kamenov, B., Peytcheva, I., von Quadt, A., Christofides, G., Xiangshen, Zh., Huang, S. 2008. New U-Pb and Ar-Ar mineral ages for the BarutinBuynovo-Elatia-Skaloti-Paranesti batholith (Bulgaria and Greece): Refinement of its debatable age. Geochemistry, Mineralogy and Petrology 46, 80-102.

Stacey, J.S., Kramers, J.D. 1975. Approximation of Terrestrial Lead Isotope Evolution by a 2-Stage Model. Earth and Planetary Science Letters 26, (2), 207-221.

Stübner, K., Drost, K., Schoenberg, R., Böhme, M., Starke, J., Ehlers, T.A. 2015. Asynchronous timing of extension and basin formation in the South Rhodope core complex, SW Bulgaria, and northern Greece. Tectonics 35, 1-24, doi:10.1002/2015TC004044.

Turpaud, P., Reischmann, T., 2010. Characterization of igneous terranes by zircon dating: implications for UHP occurrences and suture identification in the Central Rhodope, northern Greece. International Journal of Earth Sciences 99, 567-591.

Van Hinsbergen, D.J.J., Dupont-Nivet, G., Nakov, R., Oud, K., Panaiotou, C. 2008. No significant post-Eocene rotation of the Moesian Platform and Rhodope (Bulgaria): Implications for the kinematic evolution of the Carpathian and Aegean arcs. Earth and Planetary Sciene Letters 273 (3-4), 345-358.

Veit, B., Kruhl, J.H., Machev, Ph. 2003. Multiple syntectonic granitoids during the Alpine development of the Rhodope Massif (southern Bulgaria) preliminary results. Neues Jahrbuch für Geologie und Paläontologie 228, 321-341.

Vergilov, V., Kozhoukharov, D., Boyanov, I., Mavroudchiev, B., Kozhoukharova, E. 1963. Notes on the pre-Palaeozoic metamorphic complexes in the Rhodope massif. Bulletin of the Geological Institute 12, 187-211 (in Bulgarian, with English summary).

Winter, J. D. 2001. An introduction to Igneous and Metamorphic Petrology. Prentice-Hall Inc., Upper Saddle River, New Jersey; 695 pp.

Zagorčev, I. 1971. Some features of the young Alpine block structure of a part of Southwest Bulgaria. Bulletin of the Geological Institute, Series Geotectonics 20, 17-27 (in Bulgarian, with English summary).

Zagorčev, I. 1981. Belyovo conical synform (Pirin, SW Bulgaria): geometric features and development. Geologica Balcanica 11 (3), 23-45 (in Russian, with English abstract).

Zagorčev, I. 1987. Rubidium-strontium radiogeochronology of metamorphic and magmatic rocks in Southern Bulgaria. Comptes rendus de l'Académie bulgare des Sciences 5, 58-61 (in Bulgarian).

Zagorčev, I. 1989. Pirin-Pangeon Unit - tectono-metamorphic and igneous development. Second Hellenic-Bulgarian symposium, Thessaloniki, Abstracts, p. 25.

Zagorčev, I. 1991. Paleogene tectonothermal events in the Rhodope massif: isotopic and geological arguments and implications. Geologica Balcanica 21 (2), 79-82.

Zagorčev, I. 1992. Neotectonic development of the Struma (Kraistid) Lineament, southwest Bulgaria and northern Greece. Geological Magazine 129 (2), 197-222.

Zagorčev, I. 1994a. Structure and tectonic evolution of the Pirin-Pangaion Structural Zone (Rhodope Massif, south- 
ern Bulgaria and northern Greece). Geological Journal 29, 241-268.

Zagorčev, I. 1994b. Late Cenozoic extension in northeastern Greece: Strymon valley detachment system and Rhodope core complex: Comment. Geology 22 (3), 283-285.

Zagorčev, I. 1994c. Discussion on a major Oligocene-Miocene detachment in southern Rhodope controlling north Aegean extension. Journal, Vol. 150, 1992, 243-246. Journal of the Geological Society of London 151 (2), 413-414.

Zagorčev, I., Dinkova, Y. 1989. Geological map of the Republic of Bulgaria 1:100 000, Strumitsa, Petrich, Gevgeli and Sidirokastron map sheets. Committee on Geology, Company for Geophysical Surveys and Geological Mapping, Sofia.

Zagorčev, I., Dinkova, Y. 1991. Explanatory note for the geological map of Bulgaria 1:100 000. Strumitsa, Petrich, Gevgeli and Sidirokastron map sheet. Committee on Geology, Company for Geophysical Surveys and Geological Mapping, Sofia, 38 pp. (in Bulgarian).

Zagorčev, I., Moorbath, S. 1983. Rubidium-strontium dara on the age of the Dautov pluton (granitoids of Pirin type), South-west Bulgaria. Geologica Balcanica 13 (4), 31-37.

Zagorčev, I., Lilov, P., Moorbath, S. 1989. Results of Rb-Sr and $\mathrm{K}-\mathrm{Ar}$ radiogeochronological studies of metamorphic and magmatic rocks in Southern Bulgaria. Geologica Balcanica 19 (3), 41-54.

Zagorčev, I., Moorbath, S., Lilov, P. 1987. Radiochronological data on the Alpine igneous activity in the Western part of the Rhodope Massif. Geologica Balcanica 17 (2), 59-71 (in Russian).

Zagorčev, I., Kostadinov, T., Harkovska, A., Valeva, G., Shabatov, Y., Hristov, S., Decheva, A., Toprakchieva, V., Ivanova, M. 1971. Geology of Maleshevska Mountain. Annual Jubilee of the Committee of Geology, Sofia 18, 137-156.

Zagorčev, I., Zidarov, N., Iliev, I., Slavov, I., Shabatov, Y. 1974. On the tectonics of the Pirin horst. Annual of the State Enterprise "Geological Research" 20 (1971), 228-260 (in Bulgarian, with English abstract).

Zagorchev, I. 1995a. Pirin. Geological Guidebook. Academic Publishing House "Marin Drinov", Sofia, 70 pp.

Zagorchev, I. 1995b. Pre-Paleogene Alpine tectonics in Southwestern Bulgaria. Geologica Balcanica 25 (5-6), 91-112.

Zagorchev, I. 1998. Rhodope controversies. Episodes 21 (3), $159-168$.

Zagorchev, I. 2001. Introduction to the geology of SW Bulgaria: an overview. Geologica Balcanica 31 (1-2), 3-52.
Zagorchev, I. 2008. Amphibolite-facies metamorphic complexes in Bulgaria and Precambrian geodynamics: controversies and "state of the art". Geologica Balcanica 37 (1-2), $33-46$.

Zagorchev, I. 2014. Rhodope evolution in the heart of Balkan geology. Proceedings of the XVI Serbian Geological Congress, Donji Milanovac, 22-25.05.2014, 43-48.

Zagorchev, I. 2015. Polyphase tectonometamorphism in Bulgaria: Some alternative interpretations and ideas. Bulgarian Geological Society, National Conference with International Participation "Geosciences 2015", Abstracts, 99-100.

Zagorchev, I., Balica, C., Balintoni, I. 2015. Repeated crustal melting and ductile flow: Possible major mechanisms of Rhodope evolution. Comptes rendus de l'Académie bulgare des Sciences 68 (11), 1403-1414.

Zagorchev, I., Balica, C., Kozhoukharova, E., Balintoni, I. 2016. Pirin tectonometamorphic evolution: isotopic data and partial revision. Bulgarian Geological Society, $\mathrm{Na}$ tional Conference with International Participation "Geosciences 2016”, Abstracts, 101-102.

Zagorchev, I., Balica, C., Kozhoukharova, E., Balintoni, I., Sabau, G., Negulescu, E. 2014. Palaeogene igneous evolution of the Rhodopes. Bulgarian Geological Society, National Conference with International Participation "Geosciences 2014", Abstracts, 35-36.

Zagorchev, I., Balica, C., Kozhoukharova, E., Balintoni, I., Sabau, G., Negulescu, E. 2016. Pirin tectonometamorphic evolution: new isotopic data and partial revision. Bulgarian Geological Society, National Conference with International Participation "Geosciences 2016", Abstracts, 101-102.

Zagorchev, I., Balica, C., Kozhoukharova, E., Balintoni, I., Sabau, G., Negulescu, E. 2012. Isotopic data on the age of the Krupnik granite pluton and its host rocks, Kresna horst, Krupnik Mountain, SW Bulgaria. Comptes rendus de l'Académie bulgare des Science 65 (7), 977-984.

Zagortchev, I. 1994. Alpine evolution of the pre-Alpine amphibolite-facies basement in South Bulgaria. Mitteilungen der Österreichischen Geologischen Gesellschaft 86 (1993), 9-21.

Zidarov, N., Zagorčev, I., Slavov, I., Shabatov, Y., Nedyalkova, S., Toprakchieva, V., Katseva, L., Vodencharov, Y., Gercheva, Y., Simeonov, A. 1974. Notes on the metamorphic rocks in Pirin. Annual of the State Enterprise "Geological Research” 20 (1971), 262-278 (in Bulgarian, with English summary). 